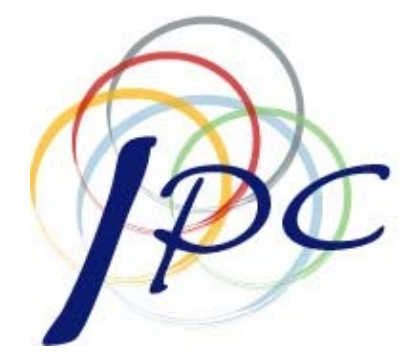

InTERnational Policy Center

Gerald R. Ford School of Public Policy University of Michigan

IPC Working Paper Series Number 30

Effects of Privatization and Ownership in Transition Economies

Saul Estrin

Jan Hanousek

Evzen Kocenda

Jan Svejnar

June 2007 


\title{
Effects of Privatization and Ownership in Transition Economies
}

\author{
Saul Estrin* \\ Jan Hanousek** \\ Evžen Kočenda** \\ Jan Svejnar***
}

June 4tht, 2007

JEL Codes: D2, L2, O1, P5

Keywords: privatization, ownership, firm performance, economic growth, transition from plan to market, economic development, Eastern Europe, China

* London School of Economics, UK, CEPR and IZA

** CERGE-EI, CEPR, WDI

*** University of Michigan, CERGE-EI, CEPR, IZA

We are thankful for helpful comments to Olivier Blanchard, Tito Boeri, Bernardo Bortolotti, Roman Frydman, Irena Grosfeld, Sergei Guriev, Derek Jones, Tomek Mickiewicz, Tom Rawski, and Andrei Shleifer, and participants at conferences and seminars including Columbia, CERGE-EI, Split, Paris Dauphine. We would like to thank Lenka Drnáková, Natalia Khorunzhina, Brian McCauley, and Vilém Semerák for research assistance and to Faith Vlcek for valuable secretarial assistance. While preparing this paper, Svejnar benefited from NSF Grant No. SBR-951-2001, and Kocenda and Hanousek benefited from GACR Grant No.402/06/1293 and FP-6 Grant No. 2005-028647. The usual disclaimer applies. 


\section{Introduction}

This paper is motivated by the ongoing debate among economists and policy makers about the efficiency and distributional effects of different methods and sequencing of privatizations around the world. Our goal is to evaluate what economists have learned to date about the economic effects of privatization, focusing on the experiences during the last 15-20 years in the post-communist (transition) economies and China, with comparative references to other developing countries.

We focus on the transition economies because they provide a useful laboratory, having experienced major changes in the values of many relevant variables as they changed their economic system. Unlike most other developing countries and until recently also China, the transition economies for instance did not merely privatize a number of key state-owned firms or strive to improve the functioning of their legal and institutional framework. As may be seen from Table 1, they carried out a major transformation that made the share of private sector in GDP increase from extremely low levels (see e.g., Estrin, 1994) to between 60\% and 90\% (see EBRD, 2006) and they instituted from scratch a market-oriented legal and institutional system (see e.g., Svejnar, 1991). ${ }^{1}$ The transition economies also differ from most other developing countries because of their relatively high level of human capital, initial lack of wealth in private domestic hands, and the heritage of anti-entrepreneurialism (see Estrin, Meyer, Bytchkova, 2006). However, they share with many other developing countries numerous characteristics associated with "weak" institutions, such as poorly conceived and/or ineffectively enforced property rights and insufficiently developed capital markets (see Acemoglu, Johnson and Robinson (2002) for a discussion of the role of institutions in economic development). One can hence obtain valuable insights about the impact of privatization by focusing on the large literature dealing with the transition economies, while bringing in for comparison key findings obtained with respect to China and other developing countries. It is appropriate to undertake a study of this type now because it has been fifteen years or more since the start of transition and one may hence draw

\footnotetext{
${ }^{1}$ However, because of their relatively low levels of development and the widespread use of "voucher privatization", transition economies only generated 5\% of the total global privatization proceeds between 1990 and 2000. The cumulative proceeds from privatization were estimated at $\$ 1.5$ trillion in 2005 (Megginson, 2005, p.21).
} 
relatively robust empirical conclusions and address more rigorously than hitherto the issues of causality.

Djankov and Murrell (2002) made a major attempt to survey this literature, applying a meta-analysis to the findings from a large number of diverse early studies, combining various indicators of performance (restructuring) into one composite measure. They found that privatization to outside owners resulted in 50 percent more restructuring than privatization to insiders (current managers or workers). Privatization to workers had no effect in Central and Eastern Europe (CEE) and a negative effect in the Commonwealth of Independent States (CIS) that replaced most of the former Soviet Union. Investment funds, foreigners and other block-holders were found to produce more than ten times as much restructuring as diffuse individual ownership. Hardening of budgets constraints (i.e. curtailing firms' access to formal or informal state subsidies) was also found to have a positive effect on restructuring. Among other factors, import competition had a positive effect on performance in CEE, but a negative effect in CIS. Overall, the authors noted that the impact of privatization on company performance was typically positive and statistically significant in CEE, but statistically insignificant in CIS. They explained this by the more widespread occurrence of insider ownership after privatization and a weaker institutional environment leading to less effective governance by outside owners in the CIS countries. Finally, the authors noted that about one-half of the studies they surveyed did not take into account the endogeneity and selection issues associated with ownership and firm performance, and they urged future research to tackle this issue.

The conclusions of Djankov and Murrell were echoed in Megginson (2005) that also surveyed the evidence on the impact of privatization in transition economies. $\mathrm{He}$ concluded that "mass" (or voucher) privatization, whereby ownership rights were distributed widely and at nominal prices, often led to disappointing outcomes, perhaps because this form of privatization was frequently associated with insider ownership. Companies where insiders gained control did poorly but firms with "real owners" (financial institutions, foreign corporations, or local entrepreneurs) were able to improve their performance. Megginson's (2005) survey was complemented by a short survey by Guriev and Megginson (2006). Both studies related the mixed results on the impact of 
privatization in transition economies to the slow progress in microeconomic and legal reform, especially in CIS countries.

These surveys have not included much detail on China, perhaps because much of the private sector development has been either through foreign direct investment (FDI), entry de novo, or through unique Chinese ownership arrangements such as the township-village enterprises. However, since the mid-1990s, many large state-owned enterprises (SOEs) in China have been commercialized (made to operate as independent commercial entities) and shares in them have been sold; allowing private owners to obtain a majority stake or $100 \%$ control. A substantial literature has emerged to study the effects of this privatization process.

In the present study we report on a number of new results, while providing stronger supporting as well as contradictory evidence with respect to some of the previous research. We provide an assessment based on a number of important and methodologically strong new studies as well as earlier analyses and we distinguish studies on the basis of their sample size, econometric methodology and indicator of performance in order to draw conclusions that take these characteristics explicitly into account. Ownership structures have evolved, leading to changes in control over firms, and so the emphasis in the literature has to some extent shifted from insider versus outsider and concentrated versus dispersed ownership to domestic as against foreign owners. Broadly, we find that privatization to foreign owners raises efficiency relative to state owned firms, although in China this result is less clear cut and relatively more estimates suggest that private domestic ownership raises TFP. The effect of domestic private ownership is by and large also found positive in the CEE region and in Ukraine, but it is quantitatively much smaller than that of foreign ownership. Russia appears to be different in that the effect of domestic private and mixed ownership is found to be negative or insignificant. Evidence from a recent firm-level data set from 26 transition economies also suggests that there is an insignificant average (across countries) effect of domestic private ownership relative to that of the state ownership. Concentrated (especially foreign) private ownership has a stronger positive effect than dispersed ownership in CEE and CIS, but foreign joint ventures rather than wholly owned foreign firms have a positive effect on TFP level in China. Worker ownership in either CEE or 
CIS (and collective ownership in China) does not seem to have a negative effect relative to other forms of private ownership. Finally, data from CEE and CIS suggest that new firms appear to be equally or more productively efficient than firms privatized to domestic owners, and foreign start-ups appear to be more efficient than domestic ones.

Turning to other measures of performance, studies of labor productivity find that private ownership has a positive or insignificant effect on labor productivity (not controlling for non-labor inputs) in CEE and CIS, and a mostly insignificant effect in China. In terms of profitability, in CEE, CIS and China the effect of private foreign and domestic ownership on profitability is found to be positive or statistically insignificant, with the significance depending on the particular type of ownership. Concentrated domestic private ownership, managerial ownership, and to a lesser extent foreign ownership generally tend to have a positive effect on profitability, while evidence from CEE also suggests that profitability is unaffected when the state keeps a golden share or workers wield more concentrated ownership. Studies of CEE and CIS countries indicate that privatization tends to have a positive effect on the scale of operation (sales revenues), while studies of the effect of private ownership on the rate of change of scale of operations (from CEE, CIS and China) suggest that this effect is generally not statistically significant.

Regarding indicators of labor market performance, studies of employment find that privatization in the post-communist economies and China is not associated with a reduction in employment, a finding that goes counter to many theoretical models, as well as evidence from some developing countries (e.g., Mexico). On the contrary, private owners tend to keep employment at higher levels than SOEs, ceteris paribus. Studies of the effects of ownership on wages find that state ownership is associated with lower wages in some countries, such as Russia and former Czechoslovakia, but not in others, such as Poland. Results from the Czech Republic suggest that there is no significant difference in the rate of return on an additional year of education between state-owned, privatized and newly established private firms, but that private firms reward university education more than SOEs. In Russia, where in the 1990s firms tended to owe wages to their workers, SOEs were more likely to exhibit wage arrears than other types of firms. Many studies examined the effect of privatization on other indicators and while the broad 
range of indicators precludes a simple summary, the results exhibit a pattern that is in line with the above measures of performance. We provide a more detailed exposition of these findings and our interpretation of them in the remainder of this paper.

The structure of the paper is as follows. In Section 2 we discuss the experience of privatization in the transition economies and more generally around the world, as well as the economic effects of privatization and the principal methodological and data issues encountered in the literature. We also outline the key systemic changes and policies that, along with privatization, were advocated and in part or fully carried out during the transition. In sections 3 and 4, we examine the macro- and micro-economic evidence about the determinants, extent and impact of privatization, and we survey and evaluate the existing literature and attempt to develop a coherent picture of how and why privatization has affected national and enterprise economic performance in the transition economies and China. We conclude our study in Section 5 with policy-oriented observations.

\section{Policies, Institutions, and Privatization}

While the wisdom and economic effects of privatization in CEE and CIS is currently the subject of intense re-examination, in the early 1990s privatization was widely considered one of the keystones of the entire transition process. The policy arguments were based upon a theoretical foundation (see e.g. Vickers and Yarrow, 1988; Bos, 1991) and successful experience in developed economies, notably the United Kingdom (see Bishop and Kay, 1988; Vining and Boardman, 1992). Overall, the findings from studies of developed and middle-income countries, surveyed by Megginson and Netter (2001), indicate that privatization could be expected to improve enterprise efficiency and profitability. The view that privatization could also be pivotal in the transition process was especially strongly advocated by proponents of the so called Washington Consensus, which emphasized fast transfer of ownership via privatization and belief that private ownership together with market forces would ensure better and more efficient performance of the economy (see e.g. Lipton and Sachs, 1990, and Blanchard, Dornbusch, Krugman, Layard, and Summers, 1991). Combined with price liberalization, freedom from state control was seen as the way to bring prices into line with opportunity 
costs and to harden budget constraints (see Kornai, 1990). In fact, efficiency was one of the important arguments for privatization as the transfer of ownership rights was seen as being crucial for the efficient allocation of resources and long term economic growth. From a political perspective, advocated for instance by Andrei Shleifer, privatization was viewed as necessary even if there were to be no efficiency improvements. This is because from this perspective the principal reason for privatization was to eradicate the command economic system rooted in communist ideology, of which state ownership was the backbone. As e.g. Shleifer and Treisman (2005) show, privatization was very successful from the political point of view almost from the outset, but most of the empirical work concentrates on efficiency gains. Hence we survey the efficiency related arguments in the first sub-section below.

From the start it was argued that, even from the perspective of enhancing enterprise efficiency alone, privatization on its own would not be sufficient for an effective functioning of emerging market economies. Most of the early writers on the subject of optimal strategy of the transition formulated a series of interrelated systemic changes and policy reforms that were a prerequisite for successful transition (Svejnar, 1989; Lipton and Sachs, 1990; Blanchard, Dornbusch, Krugman, Layard, and Summers, 1991; Aghion and Blanchard, 1994). Since the impact of privatization was often viewed as being dependent on the presence of other accompanying policies and systemic changes, we briefly evaluate these in the second sub-section below.

Previous surveys highlight two further issues that are likely to influence the character of the privatization process, and its impact on enterprise and national economic performance. The vast extent of privatization in the transition economies, relative to anything that had ever been attempted before, spawned considerable variation in privatization methods within as well as between countries. It was suggested at the time that "bad privatization methods", for example so-called "mass privatization" in which ownership rights were dispersed widely at nominal prices, may have led to "bad ownership structures" and therefore reduced the potential gains from privatization. We consider privatization methods in the third sub-section, before turning to a critical aspect of institutional development, the capital market, by examining the relationship between privatization and stock market development in the fourth. 


\subsection{What Were the Reasons for Privatization?}

The fall of centrally planned economic system and privatization on a global scale represent a complete reversal of the long-term efforts in the $19^{\text {th }}$ and $20^{\text {th }}$ centuries to impose either strong regulatory controls on markets or to replace markets with planning and state control. Historically state-owned enterprises were established in both the socialist and capitalist countries to ensure political control of production, better provision of public goods, more effective ways of dealing with externalities, spearheading of economic development in the absence of "well functioning" markets, and guaranteeing full employment and equitable income distribution. But the economic performance of many SOEs proved disappointing and since the early 1980s privatization started to be advocated as a means of establishing clear property rights, providing economic incentives and stimulating superior economic performance of firms and economies at large (Vickers and Yarrow, 1988). One argument for privatization stresses the different objectives and corporate governance of SOEs and privately owned firms. The objective imposed by the owner in SOEs is not necessarily consistent with conventionally defined efficiency. For example, SOEs may be required to deviate from profit maximization or cost minimization in order to satisfy political objectives, by creating or maintaining employment in economically depressed regions or by holding prices below average costs

for redistributive reasons (see e.g., Estrin and Perotin, 1991). The politicization of enterprise decision-making may also open firms up to lobbying and unproductive rent seeking (see Shleifer and Vishny, 1994, 1997).

Even if the state decides to maximize the profits of the firms that it owns, problems of corporate governance may still generate inferior performance in SOEs as compared to privately owned firms. Outside owners - whether private or state - do not have full access to the information about corporate performance that is concentrated in the hands of managers and when ownership and control are separated, firm-specific rents may be used to satisfy manager's private ambitions (Berle and Means, 1932). However, a private ownership system places some constraints on managers' discretionary behavior -- both external constraints imposed by product and capital markets and internal constraints, 
imposed via statutes, and it is often assumed that it is almost impossible for the state as owner to replicate these constraints.

In most developed economies, the constraints on managerial discretion are usually external to the firm and derive from capital markets, which could but often do not have the same effects on SOEs. The quality of managerial decision-making is an input in the choices of traders in equity markets, whose judgment on company performance is captured in the share price. If the managerial team is thought to be inefficient, the share prices will be reduced, putting pressure on managers to improve their performance, ultimately via the market for corporate control. Firms that are perceived as performing poorly can be subject to hostile take-over bids. The effectiveness of this mechanism depends however on capital market development and the concentration of share ownership. If holdings are widely dispersed, owners may face a free rider problem in which the individual returns to monitoring by each owner are less than the costs (see Shleifer and Vishny, 1997). This implies that the superiority of private ownership after privatization may depend on the degree of ownership concentration. Similarly, it has been hypothesized that privatization methods that distribute the private ownership rights to workers, so that ownership holdings are highly dispersed and the objectives of the new owners are not necessarily the maximization of profit, may also fail to generate superior governance and company performance (see Earle and Estrin, 1996 for a survey).

The mechanisms to align the incentives of managers and owners in privately owned firms may also operate through managerial shareholding and bonus payments (see Morck, Shleifer and Vishny, 1989), or as in the case of Japan or Germany, through internal constraints, with ownership beings typically highly concentrated into the hands of banks, funds or families who are granted board representation and undertake close monitoring of enterprise performance directly (see Franks and Mayer, 2001).

The argument for privatization is based on the notion that SOEs are often not subject to private capital market and managerial labor market discipline, and in these circumstances neither the competitively driven informational structure nor the market based governance mechanisms such as the market for corporate control can be substituted for in full. Moreover, although the government's ownership stake is concentrated, the state is in many cases not directly represented on the boards of public sector companies. 
In many developing economies as well as in some developed countries, family and business group ownership remains predominant, and though the ownership structures are typically highly concentrated, this ownership form is usually argued to impair company performance relative to outsider ownership structures (see Morck, Wolfenzon and Yeung, 2005). Privatization in some transition economies, especially in the former Soviet Union, has led to the emergence of diversified business groups owned by an individual or family ("oligarchs"), but the evidence suggests that they may be more efficient that other privatized companies (see Guriev and Rachinsky, 2005, and Gorodnichenko and Grygorenko, 2005).

The above arguments about the benefits of private over state ownership have had particular resonance in Central and Eastern Europe, where the failure of the socialist system was closely associated with state ownership and planning (see Gregory and Stuart, 2003). In the early phase of the transition, the weak monitoring of managers by the state as owner and the absence of external constraints gave management almost total discretion in state owned firms to follow their own objectives - rent absorption, asset stripping, employment, social targets - but rarely in pursuit of profits, cost reduction or innovation. The governance problems were exacerbated by the incentive problems caused by the softness of budget constraints (see Kornai, 1990, Dewatripont, Maskin and Roland, 2000; Kornai, Maskin and Roland, 2003), with poorly performing firms often having easier access to external investment funds than the better performing ones (Lizal and Svejnar, 2002). Moreover, Frydman, Gray, Hessel and Rapaczynski (2000) have argued that the imposition of hard budget constraints on SOEs will not induce revenue restructuring because entrepreneurial incentives associated with outside investor will still be absent. This relates to the incomplete contracts ideas of Hart and Moore that have been used to argue that state managers tend to make routine decisions whereas private owners would engage in non-routine decisions and stimulate entrepreneurship. In the presence of external shocks, privatized firms are hence thought to move more readily into new markets and product lines and hence be less likely to lay off workers than SOEs. This suggests that privatization might only be effective when control shifts to new owners, who are thereby able to change the managers. Barberis et al (1996) find efficiency gains deriving from new owners. As we discuss below, delayed privatization can also 
undermine the performance of the SOEs, since in this situation the incentives of managers become to seize assets rather than improve performance.

There were of course numerous caveats to the arguments in support of private ownership (see Bos, 1991) and these may explain some of our empirical findings below. Laffont and Tirole (1991) noted some of the welfare dilemmas when private firms provided public goods and/or had natural monopoly power. If firms have monopoly power, then privatizations can be harmful even if the productive efficiency of a firm increases, unless there are adequate regulatory controls or sufficiently rapid entry (see also Glaeser and Scheinkman, 1996). Monopoly power also creates a dilemma for the state as owner in a privatization process; firms which are privatized with monopoly power can be sold for higher prices than if the company is broken up to create a more competitive market structure (Estrin, 1994). Similarly, if corporate governance provisions for private firms are lax, company assets can be stolen and misallocated. The interaction of privatization and capital markets can be important, with privatized firms potentially drawing capital away from more productive new entrants if the lemons problem is more severe for the new entrants. Privatized firms with poor governance can undermine confidence in the financial market, thus reducing the use of these markets. One can hypothesize however that foreign-owned firms should face fewer of these problems, since their governance is set by their parent companies and subject to foreign regulations, while their resources are generally provided and monitored by their parent companies. ${ }^{2}$

\subsection{Policies in Transition Economies}

Privatization in the transition economies occurred in the context of broader systemic change and this sets the institutional and policy context for an evaluation of its impact. Thus, in the late 1980s and early 1990s, policy makers formulated initial reform strategies that focused on macroeconomic stabilization and microeconomic restructuring, along with supporting institutional and political change. Implementation varied across countries in both speed and the specifics of what occurred. Almost all transition governments plunged ahead, often in rapid big bang style, with what Svejnar (2002a)

\footnotetext{
${ }^{2}$ The importance of corporate governance from a broader perspective of "participation" has been addressed by Jones (2004).
} 
calls Type I reforms, namely macro stabilization, price liberalization and dismantling of the institutions of the communist system. The macroeconomic strategy emphasized restrictive fiscal and monetary policies; wage controls and in most cases also a fixed exchange rate. The micro strategy entailed moving quickly towards price liberalization for most goods, though usually not energy or housing. Most countries opened up rapidly to international trade, thus inducing a more efficient allocation of resources based on world market prices, and quickly reduced direct subsidies to SOEs. Finally, they introduced of some elements of a social safety net in order to make citizens be more willing to accept the disruptions associated with the introduction of a market economy.

Svejnar's Type II reforms involved the development and enforcement of laws, regulations and institutions that would ensure a successful functioning of a marketoriented economy. These reforms included the privatization of large and medium-sized enterprises, but also the establishment and enforcement of a market-oriented legal system and accompanying institutions, further development of a viable commercial banking sector and the appropriate regulatory infrastructure, labor market regulations, and parameters and institutions related to the unemployment, social security and retirement system. It was seen as important to develop and enforce a market oriented legal framework that would establish a level playing field, create well-defined property rights, permit the enforcement of contracts, and limit corruption. Given the central role of property rights in ensuring effective corporate governance in privately owned firms, the institutional framework was likely to be of particular relevance in determining the impact of privatization.

According to the EBRD's Transition Indicators (EBRD Transition Report, various years) progress in developing a market-supporting legal system was everywhere slow, although greater progress in limiting corruption and in establishing a functioning legal framework and institutions has been made in the central European and Baltic countries. In recent years, an important impetus for carrying out legal and institutional reforms in many of these countries has been the need to develop a system that conforms to that of the European Union (EU) as a prerequisite for accession (Baldwin, Francois, and Portes, 1997). In the empirical work which follows, differences in institutions and policies can be proxied by country and time specific fixed effects, or their impact inferred by comparing 
country specific studies, for example EU Accession countries versus those of the former Soviet Union.

\subsection{Privatization Methods}

Privatization was undertaken using a large variety of methods, and the literature has suggested that these may have influenced the effects on company performance. The need for large scale privatization was recognized from the outset with reasons ranging from perceived gains in economic efficiency, to increases in government revenues, to political appeal (Svejnar, 1989, Lipton and Sachs, 1990, Gupta, Ham, and Svejnar, 2000). The principal question for policy makers centered on the speed of its conduct. The arguments for fast privatization were that (a) price liberalization and other reforms would not provide sufficient incentives for SOEs to restructure and become competitive, (b) state would not be able to resist intervening in SOEs (Frydman and Rapaczynski, 1991; Boycko, Shleifer and Vishny, 1995) and (c) managers would decapitalize firms in the absence of rapid clarification of property rights (Frydman, Phelps, Rapaczynski and Shleifer, 1993; Blanchard, Dornbusch, Krugman, Layard, and Summers, 1991). In contrast, Dewatripont and Roland (1992a,b) and Roland (1994) argued that gradual privatization was needed because the political backlash to rapid privatization of all firms would be unacceptable. In particular, Dewatripont and Roland's (1992a,b) argument for gradualism was that it allowed the government to pursue a strategy that necessitated fewer workers/voters being immediately laid off and that it would reduce uncertainty. As we discuss below, however, empirical evidence shows that in most countries privatization did not bring about a reduction in employment.

In approaching the practical aspect of privatization, in addition to the political economy issues noted above, there was a major concern that managers could seize state property and claim it as their own through the so called popular privatization as occurred early on in Hungary and to some extent the other Central European economies (Svejnar, 1989, Lipton and Sachs, 1990). Some also feared that workers would claim ownership of their firms (Hinds, 1990, Lipton and Sachs, 1990), although this fear was probably exaggerated (Prasnikar and Svejnar, 1991, Ellerman, 1993, Earle and Estrin, 1996). 
In practice, the stock of domestic private savings in these countries was too small to purchase the assets being offered and foreign direct investment (FDI) had rarely been available on the scale required (Estrin, 1994). This led governments to innovate with privatization methods. Thus, though for selected firms auction or public tender methods were used, many countries also experimented with free distribution methods. So-called "mass" privatization entailed placing into private hands vouchers of a value sufficient to purchase those state assets to be privatized.

Virtually all privatization strategies facilitated a rapid change in ownership structure in most transition economies. With the exceptions of Hungary and Poland, few countries had contained a private sector of any significance in 1990 (Table 1). But as early as 1995, the private sector share was already at or above 50 percent in ten countries (five countries in Central Europe, three Baltic countries, Bulgaria, and Russia), though in eight former republics of the Soviet Union, it remained below 30\%. By 2006, the private sector in thirteen additional nations had reached above 55 percent of GDP, it reached $45 \%$ in Uzbekistan, and only two laggards, Belarus and Turkmenistan, still had private sector activity below 25 percent of GDP.

This remarkable performance should not conceal real concerns about quality of privatization, and therefore about its consequences for subsequent private sector performance. For example, though retained state shareholdings were small in some of the leading transition economies, the state continued to own significant shareholdings in many others. Thus, the Russian state retained more than a 20 percent share in 37 percent of privatized firms, and only sold a 100\% share in half of them. (Earle and Estrin, 1997). In a 1999 survey of privatized firms, EBRD found that in 20 of the 23 countries, the state had retained some shares in around $20 \%$ of privatized firms, with more than a 20 percent shareholding in around 12 percent of the firms. The state kept a share of more than 15 percent of privatized firms in eight countries and more than 30 percent in a further four. Retained state ownership has also been a major factor in Chinese privatizations (Tian and Estrin, 2005). Governments have also used golden shares to maintain significant influence over the privatized SOEs.

Mass privatization was also argued to hinder the establishment of effective corporate governance, especially if long "agency chains" were created (Stiglitz, 2002). Voucher 
privatization led to ownership structures that were highly dispersed because the entire adult population of the country, or all insiders to each firm, was allocated vouchers with which to purchase the shares of the company. In many countries mass privatization also initially resulted in majority ownership by insiders. According to Earle and Estrin (1997), in Russia insiders held a majority shareholding in 75 percent of firms and outsiders in only 9 percent immediately after privatization in 1994. Estrin and Wright (1999) show this pattern of extensive insider ownership is also consistent with the evidence for other CIS countries. For example, in Ukraine, insiders owned 51 percent of shares in all privatized firms in 1997, while outsiders held 38 percent and the state held the rest (Estrin and Rosevear, 1999). Insider ownership was predominantly in the hands of workers. However, this probably created limited problems for management because worker ownership was highly dispersed. Indeed Blasi, Kroumova and Kruse (1997) argue that in Russian employee-owned firms control was effectively in the hands of management.

However, ownership structures rapidly evolved in favor of outsider ownership, even in the former Soviet Union (Estrin and Wright, 1999). The literature (e.g. Djankov and Murrell, 2002) would lead us to expect that the method of privatization would also affect the impact of privatization on company performance but this evolution of ownership structures in most transition economies, associated with the development of capital markets, suggests that these initial effects might not be sustained into the longer term. We consider the developments of capital markets below and explore the issue in the empirical sections.

\subsection{Privatization and Capital Markets}

The literature suggests that there will be a relationship between stock market development, privatization and post-privatization performance in transition countries. However, in fact this has not yet been well established. Empirical studies by King and Levine (1993), Levine and Zervos (1998), Rousseau and Wachtel (2000), Beck and Levine (2004), and Rajan and Zingales (2003) provide evidence of a positive correlation between stock market development and economic growth in developed as well as emerging markets. In the early stages of their transformation, the transition economies also needed large amounts of capital for their restructuring and the financial sector was weak with banks undercapitalized. The majority of companies were unable to generate 
profits large enough to finance the necessary restructuring through retained earnings, a situation which would call for a great deal of reliance on equity financing, to which privatization was intended to provide access.

However, though development of the capital market in transition countries was partly shaped by privatization programs, privatization methods were rarely driven by the objective of developing the capital market. For example, direct sales of state assets do not affect stock markets at the time of sale since the shares do not enter the market. ${ }^{3}$ On other hand, privatizing state assets through the stock market provides liquidity and enhances transparency. As a consequence of the mass privatization programs, large numbers of shares were put on the market without reference to listing requirements. ${ }^{4}$

Stock markets transition economies during the 1990s were often characterized by insufficient regulation, institutional fragility and weak minority shareholder protection (EBRD 1998; Bonin and Wachtel, 2003).Yet the literature has rarely considered the connection between the privatization method employed and the consequent functioning of the capital market. ${ }^{5}$ Not only does the success of certain privatization methods depend on the existence of a capital market, but as we have seen the methods also determine the post-privatization ownership structure as further trading of shares evolves. The interrelationship between privatization and capital market development has been analyzed by Fungacova and Hanousek (2006). They use data over the period 1990-2003 from the majority of transition economies to test whether and in what ways privatization has influenced capital market development. They show that while market capitalization to GDP increased suddenly following mass privatization, most of these new shares were traded only occasionally or not at all, and this illiquidity became more pronounced over time. In countries which used mass privatization, the capital market did not initially fulfill its function of providing capital resources to enterprises.

\footnotetext{
${ }^{3}$ Later on, when privatized companies grow, they may use the stock market as sources of capital.

${ }^{4}$ Though motivated in part by the desire to develop the market, these policies may have had the opposite effect, as witnessed by massive delisting of companies for the stock exchange in countries such as the Czech Republic.

${ }^{5}$ Claessens, Djankov, and Klingebiel (2000) is one of the first studies recognizing the importance of institutions and law for stock market development. It was followed by several papers (Bonin and Wachtel, 2003; Claessens, Lee, and Zechner, 2003; Berglof and Bolton, 2004) which relied heavily on its findings. The influence of capital market development on growth has been addressed in Bennett, Estrin, and Urga (2007), who do not identify a significant relationship.
} 
Despite this unpromising beginning, development of the main stock indices in the transition economies has recently begun to show improvement. This is in part because the main listed companies on these markets have in recent years been the target of developing domestic pension funds, as well as investors from developed economies. Capital market evolution has also influenced ownership structure. While some of the studies discussed below specifically control for capital market development, this important issue is usually conflated with broader institutional development and with privatization methods.

\section{Determinants, Extent and Effects of Privatization}

In this section we discuss the principal hypotheses and results of corresponding empirical tests with respect to (a) the determinants and sequencing of privatizations and (b) the effect of privatization on economic performance at both the national and enterprise level. The sequencing issue is of importance in understanding the issues of selection and endogeneity which affect studies evaluating the impact of privatization on company performance.

\subsection{The Determinants, Sequencing and Extent of Privatization}

The number of studies examining the determinants, sequencing and extent of privatization, whether in developing or developed countries, is relatively limited. Gupta, Ham and Svejnar (2000) examine theoretically and empirically the determinants of the sequencing of privatization. They note that an important fact that stands out in all largescale privatizations is that no government has privatized all SOEs simultaneously. Even in countries that strove to privatize rapidly, (e.g., the Czech Republic, Estonia, Russia, Slovakia, and the Ukraine), the process consisted of a sequence of moves, with some firms being privatized earlier than others. The authors point out that government may sequence privatization of SOEs because (a) it may incur excessively high transaction and congestion costs if it tries to privatize all firms simultaneously, (b) it wants to reveal information about the firms to investors (later buyers may observe the quality of the firms sold earlier) if there is uncertainty about the quality of the firms being privatized, (c) it wants to avoid political opposition to dramatic reforms and possibly increase the 
feasibility of future reforms (Dewatripont and Roland, 1995), and (d) it wants to avoid costly unemployment (Aghion and Blanchard, 1994, and Katz and Owen, 1993). ${ }^{6}$

Given that governments privatize sequentially, the question arises as to which firms they choose to privatize first. A number of models have been developed to capture alternative government objectives that yield predictions about the government's sequencing strategy (see Gupta, Ham and Svejnar, 2000). Glaeser and Scheinkman (1996) for instance examine sequencing strategies that would increase efficiency and argue that a primary advantage of private ownership is that it enhances efficiency by improving firms' acquisition of, and responsiveness to, information. In their model private firms respond to demand and cost shocks, but this information is unobserved or ignored by public firms. In particular, the authors assume that private firms (unlike SOEs) observe the actual values and adjust their production when demand and cost conditions change. Thus if the government is concerned about increasing efficiency in this sense, the Glaeser-Scheinkman model predicts that privatization should begin where demand or cost volatility is the greatest and where it maximizes the flow of information. Thus when demand uncertainty is greater than cost uncertainty, the authors argue that downstream firms should be privatized before upstream firms because downstream firms are better positioned to transmit information between the retail and upstream sectors. Glaeser and Scheinkman (1996) also note that the informational gains from privatization may be offset by a loss of consumer surplus if firms with significant market power are privatized and allowed to engage in monopoly pricing.

Gupta, Ham and Svejnar (2000) examine theoretically and empirically the following competing government objectives: i) maximizing Pareto efficiency through resource allocation; ii) maximizing public goodwill from the free transfers of shares to the public; iii) minimizing political costs stemming from unemployment; iv) maximizing efficiency through information gains (Glaeser-Scheinkman) and v) maximizing privatization revenues. They use firm-level data from the Czech Republic to test the competing theoretical predictions about the sequencing of privatization and find strong evidence that the government privatized first firms that were more profitable, firms in downstream

\footnotetext{
${ }^{6}$ See Gupta, Ham, and Svejnar (2000) for sequencing of privatization and Roland (2000) for sequencing of reforms.
} 
industries, and firms in industries subject to greater demand uncertainty. Privatizing more profitable firms first is inconsistent with maximizing Pareto efficiency but it is consistent with the model of maximizing privatization revenues, maximizing public goodwill and minimizing the political cost of unemployment. However, the implication of the political cost model that employment growth in the firm's industry should affect sequencing is not supported by the results. Gupta, Ham and Svejnar's (2000) finding that firms in downstream industries and in industries with greater demand uncertainty were more likely to be privatized early suggests that the government placed emphasis on efficiency in the Glaeser and Scheinkman (1996) sense, namely by privatizing first firms that required flexible management. However, in contrast to the Glaeser and Scheinkman's recommendation, but consistent with the general evidence regarding profitability, firms with higher market share were more likely to be privatized first.

Privatization, by divesting the state of key productive assets, is an unavoidably political process. Political configurations can influence the pace and timing of privatization, as was found by Bortolotti and Pinotti (2003) in their study of 21 OECD countries over the period 1977-2002. In particular, the authors found that political fragmentation gave several groups the opportunity to veto or otherwise block large-scale privatization, and hence delay or even halt the process. Politics also played a part in influencing privatization methods, with governments seeking popular support often favoring methods that dispersed share ownership.

Politics can also influence the privatization method by requiring the government to retain significant ownership stakes post-privatization. Depending on the extent of such stakes, in effect ownership is transferred without (full) control. Bortolotti and Faccio (2004) studied this phenomenon of retained state ownership stakes by examining the evolution of control structures in 141 privatized firms in OECD countries. They found that in 2000, governments were the largest stakeholder or held special control powers (e.g. a golden share) in $62.4 \%$ of these privatized firms. Contrary to what one might have expected, however, they found no evidence that these government stakes adversely affected either firms' performance or their market valuations.

Overall, the theoretical models and hypotheses about determinants and sequencing of privatization, and Gupta, Ham and Svejnar's (2000) econometric evidence, suggest that 
firms are not assigned for privatization at random. This in turn implies that studies that treat the allocation of firms for privatization as random or do not adequately control for the non-random selection are likely to overstate the positive effect of privatization on performance. Djankov and Murrell's (2002) survey for instance indicates that 47 percent of pre-2003 studies analyzing the impact of privatization on firm performance in the transition economies suffer from this problem. Realizing this shortcoming, Gupta, Ham and Svejnar (2000) analyze the problem that arises in the studies that ignore the fact that better firms may be privatized first and they show that even one of the most popular methods for controlling for selection or endogeneity in the existing studies, namely a difference-in-difference estimation (equivalent to fixed effects) approach, is unlikely fully to address this problem. ${ }^{7}$ Hence at least one-half and possibly a vast majority of the entire literature on privatization suffer from a problem of potential selection (endogeneity) bias. The general understanding of the effects of privatization and the ongoing policy work may hence be based on flawed information, a point that we illustrate in the empirical section of this paper.

In addition to sequencing, there are a number of competing theoretical models of the desirable extent of privatization. Fershtman (1990) analyzed the interdependence between the ownership status and market structure. He examined a duopolistic market, considered the implications of privatization on the attractiveness of entry, the possibility of deterring entry, and the incumbent's position as a natural monopoly. He demonstrated that a partly state-owned firm might realize higher profits than its private, profit-maximizing, competitor. ${ }^{8}$ This implies that partial rather than full privatization may be desirable in the conditions of imperfect competition, which is a feature of the early transition stage.

McFaul (1995) reviews early transition events in Russia and argues that future progress in developing private property rights will require not only sound economic policies but also more robust state institutions. Based on this exercise, he claims that the set of political institutions comprising the first post-communist Russian state was not

\footnotetext{
${ }^{7}$ Corporate performance is a function of firm's ownership. Expected performance of a firm on other hand determines potential ownership structure. As there is a two-way relationship, difference-in-differences approach may be unable to account for endogeneity.

${ }^{8}$ This result is to certain extent supported by Hanousek, Kočenda and Svejnar (2007) who study performance of privatized firms and provide results that portray the state as a more economically and socially beneficial agent than other recent studies.
} 
capable of either dismantling Soviet institutions governing property rights or creating or supporting new market-based economic institutions regarding private property. The conclusion based on his work is that the extent of privatization ought to be limited.

Leamer and Taylor (1994) develop a Bayesian pooling technique to estimate aggregate production functions for the previously centrally planned economies of Eastern Europe and for Western economies, as well as for a group of developing countries. This technique adjusts for the low quality of the data from planned economies and also possible differences between centrally planned, Western and developing country technologies. The authors find that if the transferability of assets to the new technology is low and Western capital is unavailable, it may be better not to privatize than to have full (big-bang) privatization. Large-scale privatization is also less desirable if Western capital is available for new projects. Thus, in some instances it may be desirable to use Western support to slow the rate of privatization rather than hasten it. This study predicts that large scale privatization may be more desirable in the CEE countries than the CIS ones because western capital is at least initially more available for the former than the latter.

\subsection{Privatization, Growth and Other Aggregate Outcomes}

A number of theoretical models provided competing predictions about the effects of privatization on macro-economic performance and growth, with some envisioning the effect being positive, some negative and some ambiguous. In Gylfason (1998), privatization is shown to increase national economic output in a two-sector fullemployment general-equilibrium model by enhancing efficiency as if a relative price distortion were being removed through price reform, trade liberalization, or stabilization. Gylfason shows that the static output gain from privatization may be large and the potential dynamic output gain from privatization also appears to be substantial. Hansen (1997) uses a general equilibrium imperfect competition model to show that a broad distribution of ownership rights can have favorable influence on micro-economic efficiency and may therefore lead to a 'good' aggregate outcome. Sales to single or core investors, if accompanied by workers' equity shares, may perform worse. Furthermore only a so called Big Bang rapid approach to privatization might lead to favorable outcomes. 
Several studies use aggregate data to assess the effect of privatization on economic performance. Using data from thirty five developing market economies over the 19881992 period and employing Probit and Tobit models to identify the determinants of successful privatization programs, Plane (1997) finds that privatization (through divestiture) has a significant positive effect on economic growth and that the effect is stronger when privatization takes place in industry or infrastructure rather than in other sectors. This study hence considers sector of the firm (infrastructure, industry, and services) as the determinant of privatization while also including variables to control for macroeconomic development (prices, exchange rate, current account). It suggests that if economic performance is the goal of the government, privatization should occur in industry and infrastructure first.

Berkowitz and De Jong (2001) analyze whether regional differences in reform policies in Russia can account for regional differences in growth rates and conclude that to a considerable degree they can. The authors find that regions with more large-scale privatization exhibit greater formation of new (legally registered) enterprises, which in turn exhibits a strong positive correspondence with growth.

Privatization and economic growth may also be related through fiscal performance. Barnett (2000) uses macroeconomic and privatization data from 18 countries to find that privatization proceeds transferred to the budget tend to be saved and used to reduce domestic financing. His other main finding is that total privatization, as opposed to just the proceeds transferred to the budget, is correlated with an improvement in macroeconomic performance as manifested by higher real GDP growth and lower unemployment. However, this result needs to be interpreted cautiously as the evidence is not establishing causality.

In a cross-country aggregate study, Zinnes, Eilat, and Sachs (2001) use a panel data set from 25 transition countries over a period 1990-1998. The dataset includes a series of indicators representing the components of the depth of privatization and progress in transition. They find that privatization does not by itself increase GDP growth, but they suggest that a positive effect is present when privatization is accompanied by hard budget constraints and in-depth institutional reforms. 
Bennett, Estrin and Urga (2007) focus on privatization methods and use an expanded Solow-Barro empirical growth framework, in which GDP growth is associated with growth in factor inputs (capital, labor and human capital) and a number of other variables including capital market and private sector development. The authors use a panel data model and GMM estimation methods for almost all the transition economies (26 countries) for the period from 1991 to 2003. They find that countries which used mass privatization enjoyed significantly higher growth post-privatization relative to preprivatization compared to countries which used other privatization methods. They use a variety if alternative specification as well as country specific fixed effects to control for possible alternative explanations of their finding. Their study suggests that, as predicted by policy advisors at the time, the advantage of speed in privatization brought about by mass privatization may have yielded benefits in terms of economic growth. ${ }^{9}$ Contrary to the expectations of many advisors and results of the early studies surveyed by Megginson (2005), however, the analysis of Bennett, Estrin and Urga (2007) suggests that mass privatization was superior to other privatization methods as far as the effect on growth is concerned.

Using similar data, Gouret (2007) in turn provides complementary evidence showing that mass privatization resulted in a smaller positive effect on the level of GDP than the more gradual methods of privatization. Gouret also runs similar regressions as Bennett et al. (2007), using macroeconomic stabilization and reform dummy variables rather than inputs as controls. In these specifications he usually cannot reject the hypothesis that the effects of different forms of privatization on growth are not different from one another.

Since in a number of economies pre-privatization firms were to a large extent controlled by workers, Albrecht and Thum (1994) discuss strategy for economies in transition to get through a potentially destabilizing phase. Based on their theoretical model they predict that policy measures such as labor participation with wage ceilings can help avoid the destructive trend towards mass bankruptcy with negative macroeconomic impact.

\footnotetext{
${ }^{9}$ The result may be due to an increase in ownership concentration following mass privatization that had strengthened control over firms.
} 


\section{Micro Theory and Evidence}

A theoretical analysis and overview of privatization and firm performance in transition is provided by Roland (2000). ${ }^{10}$ Surveys of firm-level studies examining the effects of privatization on firm performance range from ones that find a large variation of outcomes but no systematically significant effect of privatization on performance (Bevan, Estrin and Schaffer, 1999) to those cautiously concluding that privatization improves firm performance (Megginson and Netter, 2001), to ones that are fairly confident that privatization tends to improve performance (Shirley and Walsh, 2001, and Djankov and Murrell, 2002).

This variation in the interpretation of results is brought about in part by the fact that the early studies had access to different and often somewhat limited data on firm ownership. For these reasons, many studies treat ownership as a relatively simple categorical concept and some are often unable to distinguish the exact extent of ownership by individual owners or even relatively homogeneous groups of owners. Equally important, the diversity of interpretations and findings is generated by three types of interrelated analytical problems that may be expected in early studies in the context of the rapidly changing transition economies. First, the early studies rely on short time periods with observations concentrated immediately before and after privatization. Second, the early studies (a) use small and often unrepresentative samples of firms, (b) are frequently unable to identify accurately ownership because privatization is still ongoing or because the frequent post-privatization changes of ownership are hard to detect, and (c) often combine panel data from different accounting systems. Third, as we have discussed above, many of the early studies have not been able to control adequately for the selection/endogeneity problem of ownership and their estimates of the effects of privatization may hence be biased.

In view of these problems, we have enlarged the survey of privatization studies reported by Djankov and Murrell (2002), hereafter D-M, with studies that have been published or circulated as working papers by November 2006, and we have taken into

\footnotetext{
${ }^{10}$ In a broader framework the effect of privatization on firms' performance falls within the ongoing debate in finance on the methodology of estimating the relationship between ownership and performance. See for instance Demsetz and Lehn (1985), McConnell and Servaes (1990), Barberis, Boycko, Shleifer, and Tsukanova (1996), and Morck, Wolfenzon and Yeung (2005).
} 
account pertinent information about the data and econometric techniques used by the various authors. The overlap between the studies of CEE and CIS that we evaluate and those covered by D-M is as follows: on total factor productivity we deal with 21 studies, D-M with 6 studies and we overlap on 4 studies; on labor productivity we cover 24 studies, D-M 11 and we overlap on 9; on profitability we draw on 13 studies, D-M on 2 and we overlap on 1; on sales and revenues we deal with 18 studies, D-M with 8 and we overlap on 3; on employment we draw on 18 studies, while D-M do not study the effect on this variable; on wages we evaluate 6 studies, D-M 2 and we overlap on 2; and on other measures of performance we deal with 34 studies; D-M with 15, and we overlap on 5. Many studies have hence come on stream since the publication of the D-M paper. Moreover, some of the papers cited in D-M were working papers that came up with somewhat different estimates in the final published versions.

Since the studies are heterogeneous with respect to their methodologies and the nature of the data used, we classify studies as belonging to category 1, 2 or 3, with category 1 (C1) containing studies that employ at least fixed effects or use instrumental variables (IVs) to handle the selection/endogeneity problem in ownership and have a relatively large sample size (which we define as at least 200 firms in large and medium-sized countries, or at least 75 firms in small countries such as Slovenia), category 2 (C2) including studies that use fixed effects or IVs but work with smaller sample sizes than studies in C1, and category 3 (C3) having studies that use OLS with any sample size. In our evaluation, we place emphasis on studies in $\mathrm{C} 1$ and to a lesser extent $\mathrm{C} 2$.

In assessing the effects of privatization, we examine the effects on total factor productivity or TFP (Table 2), labor productivity (Table 3), profitability (Table 4), sales and revenues - capturing the scale of operation (Table 5), employment (Table 6), wages (Table 7), and other indicators of performance (Table 8). In each table, we report studies from the countries of the former Soviet bloc, Yugoslavia and Albania in Panel A, while in Panel B we report for comparison the effects of studies dealing with China.

\subsection{Total Factor Productivity (TFP)}

Productive efficiency, or total factor productivity, is of major interest since the communist economies collapsed in large part because of their increasing inability to 
sustain innovation and technical progress. In particular, central planners were relatively capable of mobilizing labor and capital resources through compulsory full employment and high rates of investment, but they had hard time increasing the amount of output that SOEs generated from any given inputs. As a result, a major expectation during the transition has been that firms would increase their TFP.

We have identified 22 studies that analyze the impact of ownership on TFP or rate of change of TFP in the transition economies, using value added, total product or sales revenues as the dependent variable and either dummy variables or percent share ownership as measures of different types of ownership. As may be seen from panel A of Table 2, 14 studies belong to $\mathrm{C} 1,3$ to $\mathrm{C} 2$ and 5 to $\mathrm{C} 3$. A number of studies have simply examined the differential effect of state versus private ownership, while others examine the effects of other sub-categories of ownership. The studies cover both the CEE and CIS regions.

With the possible exception of Russia, studies in $\mathrm{C} 1$ and $\mathrm{C} 2$ find the effect of private relative to state ownership to be positive or non-negative. Moreover, studies that break private ownership into several categories show that the overall private v. state ownership dichotomy subsumes different private ownership effects. Except for two of the three studies of Slovenia, all studies uniformly suggest that privatization to foreign owners increases efficiency. This effect of foreign ownership is strong and robust across regions. The effect of domestic private ownership is by and large also found positive in the CEE region and in Ukraine (Table 2), but it is quantitatively much smaller than that of foreign ownership (the quantitative effects are not shown in a tabular form). Russia appears to be different from Ukraine in that Sabirianova, Svejnar and Terrell (2005) and Brown, Earle and Telegdy (2006) find with large data sets the effect of domestic private and mixed ownership to be negative or insignificant. Similarly, Commander and Svejnar (2007) use a large firm-level data set from 26 transition economies and find an insignificant average (across countries) effect of domestic private ownership relative to that of the state ownership. In general, the effect of domestic private ownership appears to be more positive in the CEE region than in the CIS.

Compared to the D-M survey that found the effect of private ownership to be positive in CEE but insignificant in CIS, we hence find a strong positive effect of foreign 
ownership in both the CEE and CIS regions, and a quantitatively smaller positive effect of domestic private ownership in CEE and in Ukraine (together with a negative effect in Russia). The reason for finding a stronger positive effect than D-M is in part that we are focusing on studies in categories $\mathrm{C} 1$ and $\mathrm{C} 2$ that take into account the problem of selection/endogeneity of ownership, whereas the earlier surveys did not place as much emphasis on this issue. Indeed, the studies that we report in category C3 in Table 2 generate much more diverse effects, with a number of the estimated OLS coefficients on private (domestic and foreign) ownership being negative or insignificant. Another reason for our stronger and more uniform findings of positive effects of private ownership may be that more of our studies cover recent years and privatization may take a few years to have an effect as strong owners take control and markets start to function. Finally, institutional development is a slow process and more recent data may pertain to a more developed legal and institutional setting in most of the transition economies.

Several studies examine concentration of ownership and find that it plays an important part, with majority private ownership having mostly positive effects on TFP. The overall positive effect is again driven primarily by foreign owned firms. The effect of majority domestic private ownership tends to be positive as well, but it tends to be smaller in magnitude. As before, the effect is found to be positive in Ukraine but negative in Russia. Overall, we hence find qualified support for the hypothesis that concentrated private ownership tends to increase efficiency more than dispersed ownership.

Two studies distinguish between privatized SOEs and newly created private firms. Sabirianova, Svejnar, and Terrell (2005) use 1992-2000 firm-level data for almost all industrial firms in the Czech Republic and Russia and find that foreign start-ups are less efficient than existing foreign owned firms, but more efficient than domestic start-ups, which are in turn more efficient than existing domestic firms. This study hence suggests that new firms tend to be more efficient than firms privatized to domestic owners. Using 2002 and 2005 firm-level data from 26 transition economies, Commander and Svejnar (2007) find that domestic start up firms are less efficient than foreign owned firms but not significantly different from domestic privatized or state-owned firms. The two studies hence suggest that de novo firms are more productive than or at least as productive as SOEs privatized to domestic owners. 
Studies that examine the dynamics of productive efficiency show that foreign-owned firms improved efficiency faster than domestic private and state-owned firms in the 1990s and early 2000s. This differential effect is not detectable, however, in Commander and Svejnar's (2007) study of the 2002-2005 panel data from the 26 transition economies. It is hence possible that foreign owners brought about a sizable increase in efficiency in the period immediately after acquiring the local firms in the 1990s, but that later on the rate of change in efficiency has been on average similar in all the principal types of ownership of firms.

In view of the above results, the question naturally arises as to why the TFP effect of privatization to domestic owners has been much smaller than the TFP effect of privatization to foreign investors. Discussions with managers, policy makers and analysts suggest three leading possible explanations. The finding may reflect in part the limited skills and access to world markets on the part of the local managers. Domestically owned privatized firms are also the ones where performance-reducing activities such as looting, tunneling and defrauding of minority shareholders have been most frequent. Finally, in a number of countries the nature of the privatization process initially prevented large domestic private owners from obtaining $100 \%$ ownership stakes and insiders or the state often owned sizeable holdings. It often took these large shareholders several years to squeeze out minority shareholders and in the process the large shareholders sometimes artificially decreased the performance of their newly acquired firms in order to squeeze out the minority shareholders at low share prices.

The existing privatization studies also provide information about the effect of employee (insider) ownership on efficiency. There has been a major debate about whether employee ownership and control are associated with lower or higher efficiency and excessive use of labor (labor hoarding). ${ }^{11}$ We have found seven studies that examine the effect of employee ownership on TFP. Six estimates from both CEE and CIS countries are statistically insignificant and one (Estonia) shows a positive effect of employee ownership on TFP. These results are different from those of D-M who find the overall effect of employee ownership on performance to be insignificant in CEE and negative in CIS. One reason for this discrepancy may be the aforementioned limited

\footnotetext{
${ }^{11}$ In addition to our discussion above, see Hinds (1990), Earle and Estrin (1996), and Brada (1996).
} 
overlap between our and D-M studies in this area. Moreover, D-M report that "the results for managers and workers show a considerable degree of sensitivity to how selection bias is handled", while we focus on studies that handle the issue of selection (categories C1 and C2). Finally, D-M recalculate some estimates (e.g., in their Table 1) for the sake of comparability across studies, while we present the effects as reported in the original studies.

Simoneti, Damijan, Rojec, and Majcen (2005) use Slovenian data to test for the effect of a firm being listed or not listed on a stock exchange, relative to being government controlled. They find that the TFP effect of being listed is positive, while being privately controlled and non-listed has no significant effect relative to state control. This study hence supports the hypothesis that listing induces monitoring, better corporate governance and superior performance.

As mentioned in the introduction, we have also surveyed the ownership-related studies that have been carried out on data from China. Probably because privatization is a relatively recent phenomenon in China, a number of studies, including Jefferson and Rawski (1996), address TFP issues with firm level data but do not examine differences in TFP related to privatization or ownership. As may be seen from Panel B of Table 2, studies that address these issues find diverse results, with the effect of non-state ownership being mostly positive but sometimes statistically insignificant and sometimes negative. Thus Jefferson and Su (2006) use a large sample of firms ( $>20,000)$ and show that the effect of private joint stock ownership on the level of TFP is positive. $\mathrm{Hu}$, Song, and Zhang (2004) in turn use a much smaller sample of firms in selected regions $(\mathrm{N}>700)$ and find the effects of cooperative as well as domestic and foreign private ownership to have a positive effect on the level of productivity. Yusuf, Nabeshima, and Perkins (2006) use a relatively large sample of firms $(\mathrm{N}>4,000)$ and find the effect of domestic private, collective and complete foreign ownership on the level of productivity to be statistically insignificant, the effect of foreign joint ventures to be positive, unreformed state ownership negative, and reformed state ownership positive. Finally, Dong, Putterman, and Unel (2006) use firm-level data from Nanjing ( $\mathrm{N}=165)$ to examine the effect on the rate of change of TFP, and they find the effect of state urban 
ownership to be positive, while the effect of state rural and both private urban and private rural ownership is found to be insignificant.

The TFP studies of CEE, CIS and China, hence generate a variety of results. The CEE and CIS results suggest that privatization to foreign owners rather than domestic ones raises efficiency relative to state owned firms. In China, this result is less clear cut and relatively more estimates suggest that private domestic ownership raises TFP, though not the rate of change of TFP. Similarly, concentrated (especially foreign) private ownership has a stronger positive effect than dispersed ownership in CEE and CIS, but foreign joint ventures rather than wholly owned foreign firms have a positive effect on TFP level in China. Worker ownership in CEE and CIS (collective ownership in China) does not seem to have a negative effect relative to other forms of private ownership. Finally, data from CEE and CIS suggest that new firms appear to be equally or more efficient than firms privatized to domestic owners and foreign start-ups appear to be more efficient than domestic ones.

\subsection{Labor Productivity}

Estimates of the effect of ownership on labor productivity (not controlling for the use of others inputs) are based on twenty four studies, with 8 belonging to category $\mathrm{C} 1$ and 6 to category $\mathrm{C} 2$. The results of these studies have a less clear-cut interpretation since differences across types of firms could be due to different efficiency or simply to different non-labor (especially capital) factor intensity.

As may be seen from Table 3, the findings of $\mathrm{C} 1$ and $\mathrm{C} 2$ studies are similar to the TFP results in that they suggest that the effect of private ownership is primarily positive or insignificant. Similarly, as in the case of TFP, foreign ownership and concentrated ownership are found to have a positive or insignificant effect, while the effects of employee and management ownership are estimated to be mostly statistically insignificant. Finally, newly established firms are found to have lower labor productivity than others in some studies but not in others, but this may be brought about by a scale effect. Using the population of large and medium sized firms in the Czech Republic, Hanousek, Kočenda, and Svejnar (2007) find that ownership by domestic industrial companies and investment funds generates lower labor productivity than all other types of ownership (including state) and that ownership by foreign industrial companies has a 
positive productivity effect. Government retention of a golden share (veto power over certain key decisions) appears to have an insignificant effect.

The corresponding studies of firms in China, reported in Panel B of Table 3, yield mostly insignificant estimates of the effects of private/non-state ownership on labor productivity, with only one estimate being positive. Among studies that belong to Category C1 and C2, Song and Yao's (2004) study is based on the largest data set (N = 3290) and finds the effect of private ownership and control to be insignificant, as does Dong, Putterman, and Unel (2006) using relatively small data set (165 firms), Li and Rozelle (2004) who find labor productivity to be unaffected by government's share of ownership, and Sun and Tong (2003) who find no effect of state being a co-owner or a full owner. Only Hu, Song, and Zhang (2004) find a positive effect of domestic private ownership, but not of foreign or collective private ownership in an IV framework applied to a sample of 736 firms. The insignificant effects are surprising because the stylized facts and the theories developed on the basis of these facts (e.g., Gordon and Li, 1999) portray the private sector as being more productive and paying higher wages than the state sector.

Overall, the effects of all types of private ownership on labor productivity (not controlling for non-labor inputs) are found to be positive or insignificant in CEE and CIS, and mostly insignificant in China.

\subsection{Profitability}

Profitability can be a very important indicator of company performance, although in the transition economies, as in many other developing countries, profits may be underreported by firms to evade taxes, and may reflect market power as well as technical efficiency. As may be seen from Panel A of Table 4, the effects of ownership on profitability or rate of change of profitability have been examined in thirteen studies, 6 of which belong to category $\mathrm{C} 1$, and 4 to $\mathrm{C} 2$. Most studies use data from the Czech Republic and Ukraine, but some use data from Belarus, Bulgaria, FYR Macedonia, and Russia.

Foreign ownership tends to have a positive or insignificant effect on the level of profit, while the few studies that look at the effect of foreign ownership on the rate of change of profitability find it to be insignificant. The effect of domestic private 
ownership is also for the most part positive or insignificant. The effect varies across types of ownership (bank, investment fund, individual, etc.), with the positive effects in the case of foreign owners being brought about by industrial (non-financial) companies as owners, while in the case of domestic owners it is usually some form of financial ownership that generates positive effects on profit. In this finer categorization, however, the effects vary across studies. Interestingly, using data from the Czech Republic, Weiss and Nikitin (2002) find a positive effect of national (state) ownership on the rate of change of both operating profit per worker and operating profit per unit of capital, as well as a positive effect of municipal ownership on the rate of change of operating profit per worker. Using data of the publicly traded firms in the Czech Republic during 1993-1995, Hanousek and Kočenda (2003) in turn find a positive effect of foreign majority ownership on the rate of change in returns on assets. Finally, Hanousek, Kočenda, and Svejnar (2007) find positive effect of the subsequent ownership by banks on change in ROA but this effect is offset by negative effect of change in ownership. Foreign industrial owners exhibit positive effect of initial ownership on profit over sales, while effect of subsequent ownership by others foreign owners is negative. Overall, profitability is not significantly affected by the state keeping a golden share.

Three studies in categories $\mathrm{C} 1$ and $\mathrm{C} 2$ look at ownership concentration. In the Czech Republic, Hanousek, Kočenda, and Svejnar (2007) find no effect of concentration that results from the initial large scale privatization, but they find a positive effect of majority ownership by domestic private owners as a result of ownership changes that took place after privatization. In terms of foreign ownership, the authors do not find any effect of high (majority) concentration among foreign owners, but do find that strong (blocking) minority (33-49\%) foreign ownership has a positive effect on return on assets. Miller (2006) finds the effect of concentrated ownership on return on assets to be positive in Bulgaria, while Simoneti and Gregoric (2004) find concentrated management (but not employees) ownership to have a positive effect on profit/sales in Slovenia. Hence, concentrated domestic private ownership, managerial ownership, and to a lesser extent foreign ownership tend to have a positive effect on profitability, while state keeping a golden share or concentration of worker ownership appear to be unrelated to profitability. 
Studies of the effects of ownership on profit of firms in China vary considerably in terms of their methodology, sample size and findings (see Panel B of Table 4). Among the studies in Category 1 and 2, Jefferson and Su (2006) use their large sample of firms ( $N>20,000)$ to find the effect of private ownership on profit/sales to be positive but significant only at the $10 \%$ test level. Dong, Putterman, and Unel (2006) find in their small data set from Nanjing $(\mathrm{N}=165)$ that the effect of state urban and private rural ownership is positive, while that of state rural and private urban ownership is negative. Sun and Tong (2003) use a relatively small 1994-98 panel data set of listed firms ( $\mathrm{N}=$ 634) to examine the effect of ownership on three indicators of profitability. They find that (a) there is no difference in the effect of state, private domestic and private foreign ownership on EBIT/sales, (b) private domestic ownership has a positive effect, while state and private foreign ownership have no effect, on return on sales, and (c) private domestic and foreign ownerships have a positive while state has a negative effect on market/book value of the firm.

Several studies of China examine ownership concentration, with Song and Yao (2004) finding with data from eleven cities $(\mathrm{N}=3,290)$ that state and private majority ownership has a positive effect relative to non-majority state and private ownership, with the latter not being significantly different from one another. Tian and Estrin (2005) in turn use 1994-98 firm-level panel data $(\mathrm{N}=2660)$ to find that state having small shareholding has the largest positive value on corporate value, followed by high state shareholding, while intermediate state shareholding has the lowest effect. Finally, Sun and Tong (2003) find that majority state or foreign ownership does not have a significant effect on the operating income/sales ratio.

In CEE, CIS and China, the effect of private foreign and domestic ownership on profitability is hence found to be positive or statistically insignificant, with the significance depending on the particular type of ownership. Concentrated domestic private ownership, managerial ownership, and to a lesser extent foreign ownership generally tend to have a positive effect on profitability, while evidence from CEE also suggests that profitability is unaffected by when the state keeps a golden share or workers wield a more concentrated ownership. 


\subsection{Sales and Revenues}

Estimated effects of different types of ownership on sales or revenues (capturing the scale of operation) are reported in Table 5. The estimated coefficients are based on 20 studies, with 8 of them in category $\mathrm{C} 1$, and 6 in category $\mathrm{C} 2$. Some studies use sales and some the rate of change of sales as their dependent variable. Most of the $\mathrm{C} 1$ and $\mathrm{C} 2$ studies find private ownership to have a positive effect on the level of sales, suggesting that private ownership results in an increase in the scale of operations. Studies examining the effect of privatization on the rate of change of sales show that the effect is mostly insignificant but positive in the case of ownership by foreign industrial firm (Hanousek, Kočenda, and Svejnar, 2007) and ownership by outsiders and domestic as well as foreign financial firms (Frydman, Gray, Hessel, and Rapaczynski, 1999; Frydman, Hessel, and Rapaczynski 2000). The effect is insignificant for ownership by insiders, domestic nonfinancial firms, and domestic individuals. Studies in category 3 find both of the above effects to be statistically weaker and occasionally negative.

Studies of China deal with the effect of ownership on the rate of change in sales or revenues per worker. The results are summarized in Panel B of Table 5. Using their Nanjing data, Dong, Putterman, and Unel (2006) find that the effects of state urban and state rural ownerships on the rate of change of revenues per worker are positive, while those of private urban and private rural ownership are statistically insignificant. These results suggest that state ownership results in a faster rate of increase of the scale of operation than private ownership. Jia, Sun, and Tong (2005) find the effect of state minority ownership on the change in real sales to be insignificant but do not report other categories of ownership and do not specify a base. On other hand, Sun and Tong (2003) estimate this effect to be negative for state majority ownership, insignificant for foreign majority ownership and positive for companies listed on the stock exchange.

Overall, the studies of CEE and CIS countries indicate that privatization tends to have a positive effect on the scale of operation, while studies of the effect of private ownership on the rate of change of scale of operations (from CEE, CIS and China) suggest that this effect is not statistically significant except in some well defined categories of ownership. 


\subsection{Employment}

The effect of privatization on employment, like on revenues, is an indicator of the extent of restructuring brought about through privatization. As such, it provides an important empirical link to the theoretical models of transition.

Seventeen studies have examined the effect of ownership on employment or rate of change of employment, with thirteen of them belonging to categories $\mathrm{C} 1$ or $\mathrm{C} 2$. As may be seen from Panel A of Table 6, there is a tendency for privatized firms, especially those with foreign owners, to increase or not to reduce employment relative to firms with state ownership, ceteris paribus. In the early-to-mid 1990s, when employment was falling in many transition economies, this relationship amounted to a smaller or similar decline in employment in the privately owned, especially foreign owned, firms as in the SOEs. This is very different from the negative employment effect found in the Mexican privatized firms by LaPorta and Lopez-de-Silanes (1999). An interesting result is a time pattern related to privatization and employment in Polish firms identified by Mickiewicz, Gerry, and Bishop (2005) who show no significant effect on employment in the first three years after privatization, a significant positive effect about 3-6 years after privatization, and no significant effect afterwards.

In general, employee ownership and control do not have a significant effect on employment, providing parallel evidence to the TFP studies that this form of ownership does not result in excess employment.

Using a large 1980-90 sample of firms in China, Lane, Broadman, and Singh (1998) find a negative effect of the state and collective ownership on both job creation and job destruction (Panel B of Table 6) but no control group is presented. The effect on job destruction appears to be marginally larger than that of the job creation but the authors did not formally test for a difference between the two effects. In a C3 paper, Wei, Varela, D’Souza, and Hassan (2003) examine the effect of state and private foreign ownership in newly privatized firms on the change in employment over the 1990-1997 period. They find that state ownership has a negative employment effect, while the effect in the case of newly privatized firms with foreign ownership is insignificant.

The studies of employment hence find that privatization in the post-communist economies and China is not associated with a reduction in employment, a phenomenon 
that is assumed in many theoretical models and which was documented in some developing countries (e.g., Mexico). On the contrary, private owners tend to keep employment at higher levels than SOEs, ceteris paribus.

\subsection{Wages}

Studies of the effects of ownership on wages ( 3 in category $\mathrm{C} 1$ and 2 in category C3) find that state ownership is associated with lower wages in some countries, such as Russia and former Czechoslovakia, but not in others, such as Poland (see Table 7). Munich, Svejnar and Terrell's (2005) study of the rate of return to human capital in the Czech Republic suggests that there is no significant difference in the rate of return on an additional year of education between state-owned, privatized and newly established private firms, but that private firms reward university education more than SOEs. Private firms also tend to have steeper and more concave experience-earnings profiles - paying higher returns on a year of experience to employees with low experience (recent entrants into the labor market) and lower returns to the more experienced (older) workers.

In Russia, where in the 1990s firms tended to owe wages to their workers, SOEs were more likely to exhibit wage arrears than firms with domestic and foreign private ownership, firms with mixed ownership and de novo firms (Earle and Sabirianova, 2002, Lehmann, Wadsworth, and Acquisti, 1999). Hence, during this period private ownership was associated with a greater adherence to labor contracts than state ownership. ${ }^{12}$

\subsection{Other Indicators of Performance}

At least 35 studies have analyzed the effect of ownership on other dependent variables ( 8 in category $\mathrm{C} 1$ and 11 in category $\mathrm{C} 2$; Table 8 ). The following patterns of private ownership effects seem to be broadly supported by the data: (a) private ownership tends to result in higher exports and greater efficiency, as measured by the cost of inputs relative to sales, Tobin's Q, and soft budget constraints, (b) foreign firms tend to restructure and sell assets more than others (Djankov, 1999b), are more likely to pay dividends (Bena and Hanousek, 2006), and are less likely to default on debt (Frydman, Hessel, and Rapaczynski, 2000). Despite the fact that the broad range of indicators used in the studies precludes a unified summary, the results exhibit a pattern that is in line shown by other indicators.

\footnotetext{
${ }^{12} \mathrm{We}$ did not find studies comparing wage effects of different types of ownership in China.
} 


\section{Concluding Observations}

The transformation of the former communist countries from almost completely stateowned to mostly privately-owned economies is one of the more fundamental events in recent economic history. Given the relatively poor performance of the centrally planned economies before the transition, most policy makers expected privatization to result in improved economic performance. As it turned out, the post-communist countries went through a deep recession in the first three to eight years of the transition, a period that usually coincided with the launch of privatization. Yet, they have been among the fastest growing economies in the last ten to fifteen years. There is some preliminary evidence that these phenomena may be related.

The effects of privatization on performance at the micro-economic level is on the whole positive, but not uniformly so. The fact that firms have not been assigned for privatization at random also makes unbiased econometric inference difficult. Better firms seem to have been assigned for privatization first, thus making it likely that OLS estimates comparing the performance of privatized and non-privatized firms overestimate the positive effect of privatization. There is relatively clear evidence that privatization to foreign owners raises efficiency relative to that of state-owned firms, although in China this result is less clear-cut and relatively more estimates suggest that private domestic ownership raises TFP. ${ }^{13}$ The effect of domestic private ownership is by and large also positive in the CEE region and in Ukraine, but it is quantitatively much smaller than that of foreign ownership. Russia (and possibly other CIS countries that have not been rigorously analyzed) is different in that the performance effect of privatization to domestic owners is found to be negative or insignificant.

In addition, concentrated (especially foreign) private ownership has a stronger positive effect on performance than dispersed ownership in CEE and CIS, but foreign joint ventures rather than wholly owned foreign firms have a positive effect on TFP level in China. Worker ownership in CEE and CIS (collective ownership in China) does not seem to have a negative effect and data from CEE and CIS suggest that new firms are equally or more productively efficient than firms privatized to domestic owners and

\footnotetext{
${ }^{13}$ The absence of studies in category $\mathrm{C} 1$ for China, may explain why the results are less clear-cut.
} 
foreign start-ups appear to be more efficient than domestic ones. Many studies have examined the effect of privatization on other indicators and they yield results that are broadly in line with the findings on TFP.

The results highlight the importance of good management and corporate governance, access to world markets, and the presence of a functioning legal and institutional framework. For the former state owned firms, this restructuring is most easily and effectively achieved by foreign ownership. Foreign firms routinely bring in capable expatriate managers and invest heavily in training local managers. They sell the products through their global distributional networks, introduce a relatively advanced system of corporate governance and stress the importance of business ethics. Corporate governance of foreign firms hence compensates to a considerable extent for the underdeveloped legal and institutional system in many transition economies. While some domestic firms have also developed good corporate governance, the underdeveloped legal system has allowed local managers (or block shareholders) in many privatized firms to maximize their own benefits at the expense of corporate performance and hence welfare of (other) shareholders as well as stakeholders such as workers and government treasury. This is likely to account for the limited positive performance effects of privatization to domestic private owners as compared to the performance of firms privatized to foreign investors. Interestingly, in China the constraints on foreign firms together with a relatively functioning legal system have diminished the difference between the performance of private domestic and foreign firms, and made domestic-foreign joint ventures the most productive form of corporate ownership.

The most important policy implication of our survey is that privatization per se does not guarantee improved performance, at least not in the short run. Type of private ownership, corporate governance, access to know-how and markets, and the legal and institutional system matter for restructuring and performance. Foreign ownership tends to have a positive effect on performance. The positive effect of privatization to domestic owners, to the extent that it exists, takes a number of years to materialize. 


\section{References:}

Acemoglu, Daron, Simon Johnson, and James A. Robinson. 2001. "The Colonial origins of Comparative Development: An Empirical Investigation,” American Economic Review, 91(5): 1369-85.

Aghion, Philippe, and Olivier Blanchard. 1994. "On the Speed of Transition in Central Europe.“ NBER Macroeconomics Annual, 283-320.

Akimova, Irina, and Gerhard Schwodiauer. 2000. "Restructuring Ukrainian Enterprises after Privatization: Does Ownership Matter?” Atlantic Economic Journal, 28(1): 48-59.

Akimova, Irina, and Gerhard Schwodiauer. 2004. “Ownership Structure, Corporate Governance and Enterprise Performance: Empirical Results for Ukraine.” International Advances in Economic Research, 10(1): 28-42.

Albrecht, Barthold and Marcel Thum. 1994. "Privatization, Labor Participation, and the Threat of Bankruptcy: The Case of Poland." Journal of Institutional and Theoretical Economics, 150(4): 710-25.

Andreyeva, Tatyana. 2003. "Company performance in Ukraine. What governs its success.” Economics Education and Research Consortium Working Paper 03/01.

Angelucci, Manuela, Saul Estrin, Jozef Konings, and Zbigniew Zólkiewski. 2002. "The Effect of Ownership and Competitive Pressure on Firm Performance in Transition Countries: Micro Evidence from Bulgaria, Romania and Poland.” The William Davidson Institute Working Paper 434.

Bakanova, Marina, Saul Estrin, Igor Pelipas, and Sergei Pukovic. 2006. "Enterprise Restructuring in Belarus.” William Davidson Institute Working Paper 823.

Baldwin, Richard E., Joseph F. Francois, and Richard Portes. 1997. "The Costs and Benefits of Eastern Enlargement: The Impact on the EU and Central Europe.” Economic Policy, 12(24): 125-76.

Barberis, Nicholas, Maxim Boycko, Andrei Shleifer, and Natalia Tsukanova. (1996). "How Does Privatization Work? Evidence from the Russian Shops", Journal of Political Economy, 104: 764-90.

Barnett, Steven. 2000. "Evidence on the Fiscal and Macroeconomic Impact of Privatization.” IMF working paper 130.

Basu, Swati, Saul Estrin, and Jan Svejnar. 1997. "Employment and Wage Behavior of Enterprises in Transitional Economies: The Cases of Poland and Czechoslovakia.” Economics of transition, 5(2): 271-87. 
Batjargal, Bat. 2000. “The Dynamics of Entrepreneurial Networks in a Transitional Economy: The Case of Russia.” William Davidson Institute Working Paper 350.

Beck, Thorsten, and Ross Levine. 2004. "Stock Market, Banks and Growth: Panel Evidence.” Journal of Banking and Finance, 28(3): 423-42

Bena Jan, and Jan Hanousek. 2006. "Rent Extraction by Large Shareholders: Evidence Using Dividend Policy in the Czech Republic.” FMG Discussion Paper No 556, Financial Markets Group, London School of Economics.

Bennett, John, Saul Estrin, and Giovanni Urga. 2007. "Privatization Methods and Economic Growth in Transition Economies”, Forthcoming in Economics of Transition.

Berkowitz, Daniel, and David N. De Jong. 2001. "Policy Reform and Growth in PostSoviet Russia.” European Economic Review, 47(2): 337-52.

Berglof, Erik, and Patrick Bolton. 2004. "The Great Divide and Beyond - Financial Architecture in Transition." In Financial Development and Economic Growth, ed. Charles Goodhart. Palgrave: MacMillan.

Berle, Adolf, and Gardiner Means. (1932) The Modern Corporation and Private Property. New York: Commerce Clearing House.

Bevan, Alan, Saul Estrin, and Mark Schaffer. 1999. "Determinants of Enterprise Performance during Transition.” Centre for Economic Reform and Transformation Working Paper 99/03.

Bhaumik, Sumon, and Saul Estrin. 2003. "Why Transition Paths Differ: Russian and Chinese Enterprise Performance Compared." William Davidson Institute Working Paper 525.

Bhaumik, Sumon, and Saul Estrin. 2005. "How Transition Paths Differ: Enterprise Performance in Russia and China.” William Davidson Institute Working Paper 744.

Bilsen, Valentijn, and Jozef Konings. 1998. "Job Creation, Job Destruction, and Growth of Newly Established, Privatized, and State-Owned Enterprises in Transition Economies: Survey Evidence from Bulgaria, Hungary, and Romania." Journal of Comparative Economics, 26(3): 429-45.

Bishop, Matthew, and John Kay. 1988. Does Privatisation Work? Lessons from the UK. London: Centre for Business Strategy, London Business School.

Blanchard, Olivier, Rudiger Dornbusch, Paul Krugman, Richard Layard, and Lawrence Summers. 1991. Reform in Eastern Europe. Cambridge, MA: MIT Press. 
Blasi, Joseph R., Maya Kroumova and Douglas Kruse. 1997. Kremlin Capitalism: Privatizing the Russian Economy. Ithaca and London: Cornell University Press.

Bojnec, Stefan. 1999. "Privatisation, Restructuring and Management in Slovene Enterprises.” Comparative Economic Studies 41(4): 71:102.

Bonin, John P., and Paul Wachtel. 2003. "Financial Sector Development in Transition Economies: Lessons from the First Decade.” Financial Markets, Institutions and Instruments, 12(1): 1-66.

Bortolotti, Bernardo, and Paolo Pinotti. 2003. "The Political Economy of Privatization.” Fondazione Eni Enrico Mattei Working Paper 2003.45.

Bortolotti, Bernardo, and Mara Faccio. 2004. "Reluctant Privatization.” Fondazione Eni Enrico Mattei Working Paper 2004.130.

Bos, Dieter. 1991. Privatisation: A theoretical treatment. Oxford: Claredon Press.

Boycko, Maxim, Andrei Shleifer, and Robert Vishny. 1995. Privatizing Russia. Cambridge, MA: MIT Press.

Brada, Josef C. 1996. "Privatization Is Transition - Or Is It?" Journal of Economic Perspectives, 10(2): 67-86

Brainerd, Elizabeth. 2002. "Five Years After: The Impact of Mass Privatization on Wages in Russia, 1993 - 1998." Journal of Comparative Economics, 30(1): 160-90.

Brown J. David, and John S. Earle. 2001a. "Privatization, Competition and Reform Strategies: Theory and Evidence from Russian Enterprise Panel Data.” CEPR Discussion Paper Series 2758.

Brown J. David, and John S. Earle. 2001b. "Competition Enhancing Policies and Infrastructure: Evidence from Russia.” CEPR Discussion Paper 3022.

Brown J. David, and John S. Earle. 2002. “Gross Job Flows in Russian Industry Before and After Reforms: Has Destruction Become More Creative?” Journal of Comparative Economics, 30(1): 96-133.

Brown J. David, John S. Earle, and Almos Telegdy. 2006. "The Productivity Effects of Privatization: Longitudinal Estimates from Hungary, Romania, Russia, and Ukraine.” Journal of Political Economy, 114(1): 61-99.

Carlin, Wendy, Steven Fries, Mark E. Schaffer, and Paul Seabright. 2001. "Competition and Enterprise Performance in Transition Economies: Evidence from a Cross-country Survey.” CEPR Discussion Paper 2840. 
Chen, Gongmeng, Michael Firth, and Oliver Rui. 2006. "Have China's Enterprise Reforms Led to Improved Efficiency and Profitability?” Emerging Markets Review, 7(1): 82-109.

Claessens, Stijn. 1997. "Corporate Governance and Equity Prices: Evidence from the Czech and Slovak Republics.” Journal of Finance, 52(4): 1641-58.

Claessens, Stijn, and Simeon Djankov. 1998. "Politicians and Firms in Seven Central and Eastern European Countries.” The World Bank Policy Research Working Paper 1954.

Claessens, Stijn, and Simeon Djankov. 1999. "Ownership Concentration and Corporate Performance in the Czech Republic.” Journal of Comparative Economics 27(3): 498-513.

Claessens, Stijn, and Simeon Djankov. 2002. "Privatization Benefits in Eastern Europe.” Journal of Public Economics, 83(3):307-24.

Claessens, Stijn, Simeon Djankov, and Daniela Klingebiel. 2000. "Stock Markets in Transition Economies.” World Bank Financial Sector Discussion Paper 5.

Claessens, Stijn, Simeon Djankov, and Gerhard Pohl. 1997. "Ownership and Corporate Governance : Evidence from the Czech Republic.” The World Bank Policy Research Working Paper 1737.

Claessens, Stijn, Ruben Lee, and Josef Zechner. 2003. The Future of Stock Exchanges in European Union Accession Countries. London: Corporation of London/CEPR.

Commander, Simon, and Jan Svejnar. 2007. "Do Institutions, Ownership, Exporting and Competition Explain Firm Performance? Evidence from 26 Transition Countries”, mimeo.

Csermely, Agnes, and Janos Vincze. 1999. "Leverage and Foreign Ownership in Hungary.” The Central Bank of Hungary Working Paper 1999/1.

Cull, Robert, Jana Matesova, and Mary Shirley. 2002. "Ownership Structure and the Temptation to Loot. Evidence from Privatized Firms in the Czech Republic.” Journal of Comparative Economics, 30(1): 1-24.

Dean, James W., and Tatiana Andreyeva. 2001. "Privatisation, Ownership Structure and Company Performance: The Case of Ukraine.” Journal for Institutional Innovation, Development and Transition, 5: 62-72.

Dewatripont, Mathias, Eric Maskin, and Gerard Roland. 2000. "Soft Budget Constraints and Transition.” In Planning, Shortage and Transformation, ed. Eric Maskin and Andras Simonovitz. Cambridge: MIT Press. 
Dewatripont Mathias, and Gerard Roland. 1992(a). "Economic Reform and Dynamic Political Constraints.” Review of Economic Studies, 59(4): 703-30.

Dewatripont M. and Gerard Roland. 1992(b). "The Virtues of Gradualism and the Legitimacy in the Transition to a Market Economy.” Economic Journal, 102(411): 291300.

Dewatripont Mathias, and Gerard Roland. 1995. "The Design of Reform Packages Under Uncertainty.” American Economic Review, 85(5): 1207-23.

Djankov, Simeon. 1999a. “The Restructuring of Insider-dominated Firms.”. Economics of Transition, 7(2): 467-79.

Djankov, Simeon. 1999b. "Ownership Structure and Enterprise Restructuring in six newly independent states.” Comparative Economic Studies, 41(1): 75-95.

Djankov, Simeon, and Bernard Hoekman. 2000. "Foreign Investment and Productivity Growth in Czech Enterprises.” The World Bank Economic Review, 14 (1): 49-64.

Djankov, Simeon, and Peter Murrell. 2002. "Enterprise Restructuring in Transition: A Quantitative Survey.” Journal of Economic Literature, 40(3): 739-92

Dobrinsky, Rumen, Boyko Nikolov, and Nikolay Markov. 2001. "Mark-up Pricing in Bulgarian Manufacturing." William Davidson Institute Working Paper 389.

Dobrinsky, Rumen, Nasko Dochev, Serguey Mashiah, and Nikolay Markov. 2001. "Productivity and the Sources of Firm Level Efficiency in Bulgarian Manufacturing." In Final Report on ACE Project P97-8099-R: The determinants of Firm Level Prodduction Efficiency in Poland, Romania and Bulgaria: Ownership Effects, Competition Effects and Implications for EU Enlargement, co-ordinated by Jozef Konings.

Domadenik, Polona, Janez Prasnikar, and Jan Svejnar. 2003. "Defensive and Strategic Restructuring of Firms during the Transition to a Market Economy." The William Davidson Institute Working Paper 541.

Dong, Xiao-Yuan, Louis Putterman, and Bulent Unel. 2006. “Enterprise Restructuring and Firm Performance: A Comparison of Rural and Urban Enterprises in Jiangsu Province.” Journal of Comparative Economics, 34(3): 608-633.

Dougherty, Sean M., and Robert H. McGuckin. 2002. "The Effects of Federalism and Privatization on Productivity of Chinese Firms.” EconWPA - Development and Comp Systems Working Paper 0411016.

Earle, John S. 1998. "Post-Privatization Ownership Structure and Productivity in Russian Industrial Enterprises.” SITE Working Paper 127. 
Earle, John S., and Saul Estrin. 1996. "Employee Ownership in Transition." In Corporate Governance in Central Europe and Russia. Insiders and the State, ed. Roman Frydman, Cheryl W. Gray, and Andrzej Rapaczynski. Budapest: Central European University Press.

Earle, John S., and Saul Estrin. 1997. "Privatization Versus Competition: Changing Enterprise Behavior in Russia.” William Davidson Institute Working Paper 70.

Earle, John S., and Saul Estrin. 2003. "Privatization, Competition, and Budget Constraints: Disciplining Enterprises in Russia.” Economics of Planning, 36(1): 1-22.

Earle, John S., and Almos Telegdy. 2002. "Privatization Methods and Productivity Effects in Romanian Industrial Enterprises.” Journal of Comparative Economics, 30(4): 657-82.

Earle John S., and Klara Sabirianova. 2002. "How Late to Pay? Understanding Wage Arrears in Russia” Journal of Labor Economics, 20(3): 661-707.

Earnhart, Dietrich, and Lubomir Lizal. 2006. "Effects of Ownership and Financial Performance on Corporate Environmental Performance.” Journal of Comparative Economics, 34(1): 111-29.

EBRD. various annual issues. Transition Report. London: EBRD.

Ellerman, David. 1993. "Management and Employee Buy-Outs in Central and Eastern Europe: Introduction." In Management and Employee Buy-Outs as a Technique of Privatization, ed. David Ellerman, 13-30. Ljubljana: CEEPN.

Estrin, Saul. 1994. Privatization in Central and Eastern Europe. London, U.K.: Longman.

Estrin, Saul, Klaus E. Meyer, and Maria Bytchkova. 2006. "Entrepreneurship in Transition Economies.” In Oxford Handbook of Entrepreneurship, ed. Mark Casson et al. Oxfrod: Oxford University Press.

Estrin, Saul, and Virginie Perotin. 1991. "Does Ownership Always Matter?" International Journal of Industrial Organization. 9(1): 55-72.

Estrin, Saul, and Adam Rosevear. 1999. "Enterprise Performance and Corporate Governance in Ukraine.” Journal of Comparative Economics, 27(3): 442-58.

Estrin, Saul, and Mike Wright. 1999. “Corporate Governance in the Former Soviet Union: An Overview of the Issues. Journal of Comparative Economics, 27(3): 398-421. 
Everaert, Greetje, and Antje Hildebrandt. 2001. "On the Causes of Soft Budget Constraints: Firm-Level Evidence from Bulgaria and Romania.” LICOS Discussion Paper 10901.

Faggio, Giulia, and Jozef Konings. 2003. "Job Creation, Job Destruction and Employment Growth in Emerging Market Economies.” Economic Systems, 27(2): 12954.

Fershtman, Chaim. 1990. “The Interdependence Between Ownership Status and Market Structure: The Case of Privatization.” Economica, 57(227): 319-28.

Franks, Julian; Colin Mayer. 2001. Ownership and Control of German Corporations. The Review of Financial Studies, 14(4): 943-977.

Fries, Steven, Damien Neven, and Paul Seabright. 2002. "Bank Performance in Transition Economies.” William Davidson Institute Working Paper 505.

Frydman, Roman, Marek Hessel, and Andrzej Rapaczynski. 2000. "Why Ownership Matters? Entrepreneurship and the Restructuring of Enterprises in Central Europe.” C.V. Starr Center for Applied Economics, New York University Working Paper 00-03.

Frydman, Roman, Cheryl W. Gray, Marek Hessel, and Andrzej Rapaczynski. 1999. "When does Privatization Work? The Impact of Private Ownership on Corporate Performance in Transition Economies.” Quarterly Journal of Economics 114(4) (1999): 1153-91.

Frydman, Roman, Cheryl W. Gray, Marek Hessel, and Andrzej Rapaczynski. 2000. "The Limits of Discipline: Ownership and Hard Budget Constraints in the Transition Economies.” Economics of Transition, 8(3): 577-601.

Frydman, Roman, Edmund S. Phelps, Andrzej Rapaczynski and Andrei Shleifer. 1993. "Needed Mechanisms of Corporate Governance and Finance in Eastern Europe." Economics of Transition, 1(2): 171-207.

Frydman, Roman, and Andrzej Rapaczynski. 1991. "Markets and Institutions in Large Scale Privatization: An Approach to Economic and Social Transformation in Eastern Europe", In Reforming Central and Eastern European Economics; Initial Results and Challenges, ed. Vittorio Corbo, Fabrizio Coricelli, and Jan Bossak. Washington D.C.: The World Bank.

Fungacova, Zuzana, and Jan Hanousek. 2006. "A Castle Built on Sand: The Effects of Mass Privatization on Stock Market Creation in Transition Economies.” BOFIT Discussion Paper 14.

Glaeser, Edward L., and Jose A. Scheinkman. 1996. "The Transition to Free Markets: Where to Begin Privatization.” Journal of Comparative Economics 22(1): 23-42. 
Goud, Richard B., Jr. 2003. The Determinants of Firm Performance: Empirical Evidence from 25 Countries in Central and Eastern Europe and the Former Soviet Union. Senior thesis, Reed College, Portland.

Gordon, Roger, and Wei Li. 1999. "The Effects of Wage Distortions on the Transition: Theory and Evidence from China.” European Economic Review, Elsevier, vol. 43(1): 163-83.

Gorodnichenko Yuriy, and Yegor Grygorenko. 2005. “Are Oligarchs Productive? Theory and Evidence.” EconWPA - Development and Comp Systems Working Paper 0512013

Gouret, Fabian. 2007. "Privatization and output behavior during the transition: Methods matter!” Journal of Comparative Economics, 35:3-34.

Gregory, Paul, and Robert C. Stuart. 2003. Comparative Economic Systems in the Twenty-First Century. Boston: Houghton Mifflin. (Orig. pub. 1971.)

Grigorian, David A. 2000. “Ownership and Performance of Lithuanian Enterprises.” The World Bank Policy Research Working Paper Series 2343.

Grosfeld, Irena, and Iraj Hashi. 2007. "Changes in Ownership Concentration in Mass Privatized Firms: Evidence from Poland and the Czech Republic”. Forthcoming in Corporate Governance: An International Review.

Grosfeld, Irena, and Jean-Francois Nivet. 1999. "Insider Power and Wage Setting in Transition: Evidence from a Panel of Large Polish Firms, 1988-1994.” European Economic Review, 43(4-6): 1137-47.

Grosfeld, Irena, and Thierry Tressel. 2002. "Competition and Ownership Structure: Substitutes or Complements? Evidence from the Warsaw Stock Exchange,” Economics of Transition, 10(3): 525-551.

Gupta, Nandini, John Ham and Jan Svejnar. 2000. (revised 2001). "Priorities and Sequencing in Privatization: Theory and Evidence from the Czech Republic." The William Davidson Institute Working Paper 323, forthcoming in the European Economic Review.

Gupta, Sanjeev, Christian Schiller, Henry Ma, and Erwin R. Tiongson. 2001. "Privatization, Labor and Social Safety Nets." Journal of Economic Surveys, 15(5): 64769.

Guriev, Sergei and William Megginson. 2006. "Privatization: What Have We Learned?" in Bourguignon, Francoi and Boris Pleskovic eds. Beyond Transition. Proceedings of the $18^{\text {th }}$ ABCDE, World Bank. 
Guriev, Sergei, and Andrei Rachinsky. 2005. "The Role of Oligarchs in Russian Capitalism.” Journal of Economic Perspectives, 19(1): 131-50.

Gylfason, Thorvaldur. 1998. "Privatization, Efficiency and Economic Growth.” CEPR Discussion Paper 1844.

Hanousek, Jan, and Evžen Kočenda. 2003. “The Impact of Czech Mass Privatization on Corporate Governance.” Journal of Economic Studies, 30(3/4): 278-93.

Hanousek, Jan, Evžen Kočenda, and Jan Svejnar. 2004. "Spinoffs, Privatization and Corporate Performance in Emerging Markets.” William Davidson Institute Working Paper 685.

Hanousek, Jan, Evžen Kočenda, and Jan Svejnar. 2007. “Origin and Concentration: Corporate Ownership, Control, and Performance in Firms after Privatization.” Economics of Transition, 15(1): 1-31.

Hansen, Nico A. 1997. "Privatization, Technology Choice and Aggregate Outcomes." Journal of Public Economics, 64(3): 425-42.

Hendley, Kathryn, Peter Murrell, and Randi Ryterman. 2001. "Law Works in Russia: The Role of Legal Institutions in the Transactions of Russian Enterprises" In Assessing the Value of Law in Transition Economies, ed. Peter Murrell. Ann Arbor: University of Michigan Press.

Hinds, Manuel. 1990. "Issues in the Introduction of Market Forces in Eastern European Socialist Economics.” In Managing Inflation in socialist Economies in Transition, ed. Simon Commander. Washington, D.C.: World Bank.

Hu, Yifan, Frank Song, and Junxi Zhang. 2004. "Competition, Ownership, Corporate Governance and Enterprise Performance: Evidence from China.” Hong Kong Institute of Economics and Business Strategy Working Paper 1111.

Jefferson, Gary H., Thomas G. Rawski. 1996. "Chinese Industrial Productivity: Trends, Measurement Issues, and Recent Developments, Journal of Comparative Economics, 23(xxx):146-180.

Jefferson, Gary H. and Jian Su. 2006. "Privatization and restructuring in China: Evidence from shareholding ownership, 1995-2001.” Journal of Comparative Economics, 34(1): 146-166.

Jelic, Ranko M., Richard Briston, and Wolfgang Aussenegg. 2003. "The Choice of Privatization Method and the Financial Performance of Newly Privatized Firms in Transition Economies.” Journal of Business Finance \& Accounting, 30(7-8): 905-940. 
Jia, Jin, Qian Sun and Wilson Tong. 2005. "Privatization via an Overseas Listing: Evidence from China's H-Share Firms.” Financial Management, Autumn 2005: 5-30.

Jones, Derek C. 1998. "The Economic Effects of Privatization: Evidence from a Russian Panel.” Comparative Economic Studies, 40(2): 75-102.

Jones, Derek C. 2004. "Ownership and participation: A review of the empirical evidence for Transition Economies". Advances in the Economic Analysis of Participatory and Labor managed Firms, 8: 171-209,

Jones, Derek, Mark Klinedinst, and Charles Rock. 1998. "Productive Efficiency during Transition: Evidence from Bulgarian Panel Data." Journal of Comparative Economics, 26(3): 446-64.

Jones, Derek, and Niels Mygind. 2000. "The Effects of Privatization on Productive efficiency: Evidence from the Baltic Republics." Annals of Public and Cooperative Economics, 71(3): 415-40.

Jones, Derek C., and Niels Mygind. 2002. "Ownership and Productive Efficiency: Evidence from Estonia.” Review of Development Economics, 6(2): 284-301.

Katz, Barbara G., and Joel Owen. 1993. "Privatization: Choosing the Optimal Time Path.” Journal of Comparative Economics, 17(4): 715-36.

King, Robert G., and Ross Levine. 1993. "Finance and Growth: Schumpeter Might Be Right.” Quarterly Journal of Economics, 108(3): 717-38.

Kočenda, Evžen. 2003. "Performance of Czech Voucher-privatized Firms." Prague Economic Papers, 12(2): 122-31.

Konings, Jozef, Hartmut Lehmann. 2002. "Marshall and Labor Demand in Russia: Going Back to Basics.” Journal of Comparative Economics. 30(1): 134-159.

Konings, Jozef, Hartmut Lehmann, and Mark E. Schaffer. 1996. "Job Creation and Job Destruction in a Transition Economy: Ownership, Firm Size, and Gross Job Flows in Polish Manufacturing 1988-91.” Labour Economics 3(3): 299-317.

Konings, Jozef, Patrick Van Cayseele, and Frederic Warzynski. 2005. "The Effects of Privatization and Competitive Pressure on Firms' Price-Cost Margins: Micro Evidence from Emerging Economies.” The Review of Economics and Statistics, 87(1): 124-34.

Table 8 (JEL_short_tables_April18_2007)...tam je 2001..opravila som na 2005

Konings, Jozef, and Patrick P. Walsh. 1999. "Disorganization in the Process of Transition.” The Economics of Transition, 7(1): 29-46. 
Konings, Jozef, and Ana Xavier. 2003. "Firm Performance and Selection in an Emerging Economy: Micro Evidence from Slovenia.” Royal Economic Society Annual Conference 2003, 127.

Kornai, Janos. 1990. The Road to a Free Economy. Shifting from a Socialist System: The Example of Hungary. New York: W. W. Norton.

Kornai, Janos, Eric Maskin, and Gerard Roland. 2003. "Understanding the Soft Budget Constraint.” Journal of Economic Literature, 41(4): 1095-136.

Laffont, Jean-Jacques, and Jean Tirole. 1993. A theory of Incentives in Procurement and Regulation. Cambridge, MA: The MIT Press.

Lane, Julia, Harry G. Broadman, and Inderjit Singh. 1998. "Labor Flexibility, Ownership and Firm Performance in China.” Review of Industrial Organization, 13(6): 621-35.

LaPorta, Rafael, and Florencio Lopez-de-Silanes. 1999. "The Benefits of Privatization: Evidence from Mexico.” The Quarterly Journal of Economics, 114: 11931242.

Leamer, Edward, and Mark P. Taylor. 1994. "The Empirics of Economic Growth in Previously Centrally Planned Economies.” CEPR Discussion Papers 976.

Lehmann, Hartmut, Jonathan Wadsworth, and Alessandro Acquisti. 1999. "Grime and Punishment: Job Insecurity and Wage Arrears in the Russian Federation.” Journal of Comparative Economics, 27(4): 595-617.

Levine, Ross, and Sara Zervos. 1998. "Stock Markets, Banks, and Economic Growth.” American Economic Review, 88(3): 537-58.

Li, David D., and Changqi Wu. 2002. "The Ownership School vs. The Management School of State Enterprise Reform: Evidence from China.” William Davidson Institute Working Paper 435.

Li, Hongbin, and Scott Rozelle. 2001. "Insider Privatization with a Tail: The Buyout Price and Performance of Privatized Firms in Rural China.” ARE Working Paper 01-017.

Li, Hongbin, and Scott Rozelle. 2003. "Privatizing Rural China: Insider Privatization, Innovative Contracts and the Performance of Township Enterprises." The China Quarterly, 176: 981-1005.

Li, Hongbin and Scott Rozelle. 2004. Insider privatization with a tail: the screening contract and performance of privatized firms in rural China, Journal of Development Economics 75 (2004) 1- 26 
Linz, Susan J. 1999. "Who is Shouldering the Burden of Transition? An Analysis of Depreciation Rates in Russian Industry.” Comparative Economic Studies, 41(2-3): 1-44.

Linz, Susan J. 2000. "Labor Productivity in Transition: A regional Analysis of Russian Industry.” Economic Development and Cultural Change, 48(4): 685-718.

Linz, Susan J., and Gary Krueger. 1998. "Enterprise Restructuring in Russia's Transition Economy: Formal and Informal Mechanisms." Comparative Economic Studies. 40(2): 5-52.

Lipton, David, and Jeffrey Sachs. 1990. "Creating a Market Economy in Eastern Europe: The Case of Poland.” Brookings Papers on Economic Activity, 1990(1): 75-147.

Lizal, Lubomir, and Jan Svejnar. 2002. "Investment, Credit Rationing and the Soft Budget Constraint: Evidence from Czech Panel Data." The Review of Economics and Statistics, 84(2): 353-70.

Lskavyan, Vahe, and Mariana Spatareanu. 2006. “Ownership Concentration, Market Monitoring and Performance: Evidence from the UK, the Czech Republic and Poland.” Journal of Applied Economics, 9(1): 91-104.

Maurel, Mathilde. 2001. "Investment, Efficiency, and Credit Rationing: Evidence from Hungarian Panel Data.” William Davidson Institute Working Paper 403.

McConnell, John J., and Henri Servaes. 1990. "Additional Evidence on Equity Ownership and Corporate Value.” Journal of Financial Economics, 27(2): 595-612.

McFaul, Michael. 1995. "State Power, Institutional Change, and the Politics of Privatization in Russia.” World Politics, 47(2): 210-43.

Megginson, William L. 2005. The Financial Economics of Privatization. New York: Oxford University Press.

Megginson, William L., and Jeffrey Netter. 2001. "From State to Market: A Survey of Empirical Studies on Privatization.” Journal of Economic Literature, 39(2): 321-389.

Mickiewicz, Tomasz, Christopher J. Gerry, and Kate Bishop. 2005. "Privatisation, corporate control and employment growth: Evidence from a panel of large Polish firms, 1996-2002”. Economic Systems, 29(1): 98-119.

Miller, Jeffrey. 2006. “Evaluation of Mass Privatization in Bulgaria.” William Davidson Institute Working Paper 814.

Morck, Randall, Andrei Shleifer, and Robert W. Vishny. 1989. "Alternative Mechanisms for Corporate Control”. American Economic Review. 79(4): 842-52. 
Morck, Randall, Daniel Wolfenzon, and Bernard Yeung. 2005. "Corporate Governance, Economic Entrenchment, and Growth.” Journal of Economic Literature, 43(3): 655-720.

Munich, Daniel, Jan Svejnar, and Katherine Terrell. 2005. "Returns to Human Capital under the Communist Wage Grid and During the Transition to a Market Economy.” The Review of Economics and Statistics, 87(1): 100-23.

Orazem, Peter F., and Milan Vodopivec. 2004. "Do Market Pressures Induce Economic Efficiency? The Case of Slovenian Manufacturing, 1994-2001.” World Bank Policy Research Working Paper 3189.

Perevalov, Yuri, Ilya Gimadii, and Vladimir Dobrodey. 2000. "Does Privatization Improve Performance of Industrial Enterprises? Empirical Evidence from Russia.” : 33763.

Pissarides, Francesca, Miroslav Singer, and Jan Svejnar. 2003. “Objectives and Constraints of Entrepreneurs: Evidence from Small and Medium Size Enterprises in Russia and Bulgaria.” Journal of Comparative Economics, 31(3): 503-31.

Pivovarsky, Alexander. 2001. "How Does Privatization Work?: Ownership Concentration and Enterprise Performance in Ukraine.” IMF Working Paper 01/42.

Pivovarsky, Alexander. 2003. “Ownership Concentration and Performance in Ukraine’s Privatized Enterprises.” IMF Staff Papers, 50(1): 10-42.

Plane, Patrick. 1997. "Privatization and Economic Growth: An Empirical Investigation from a Sample of Developing Market Economies.” Applied Economics, 29(2): 161-78.

Pohl, Gerard, Robert E. Anderson, Stijn Claessens, and Simeon Djankov. 1997. "Privatization and Restructuring in Central and Eastern Europe: Evidence and Policy Options.” World Bank Technical Paper 368.

Prasnikar, Janez, and Jan Svejnar. 1991. "Workers Participation in Management vs. Social Ownership and Government Policies: Yugoslav Lessons for Transforming Socialist Economies.” Comparative Economic Studies, 33(4): 27-46.

Prasnikar, Janez, and Jan Svejnar. 1998. "Investment and Wages during the Transition: Evidence from Slovene Firms.” William Davidson Institute Working Paper 184.

Qi, Daqing, Woody Wu, and Hua Zhang. 2000. "Shareholding Structure and Corporate Performance of Partially Privatized Firms: Evidence from Listed Chinese Companies.” Pacific Basin Finance Journal 8, 587-610. 
Qing Gong, Yang. 2004. "Has China's Economic Reform Improved Enterprise Performance? A DEA Evaluation of China's Large and Medium Enterprises.” ESRC Centre for Business-Working paper 287.

Rajan, Raghuram G., and Luigi Zingales. 2003. "The Great Reversals: The Politics of Financial Development in the Twentieth Century.” Journal of Financial Economics, 69(1): 5-50.

Roland, Gerard. 1994. "On the Speed and Sequencing of Privatization and Restructuring.” The Economic Journal, 104(426): 1158-68.

Roland, Gerard. 2000. Transition and Economics: Politics, Markets and Firms. Cambridge, MA: MIT Press.

Rousseau, Peter L., and Paul Wachtel. 2000. "Equity Markets and Growth: Crosscountry Evidence on Timing and Outcomes, 1980 - 1995.” Journal of Banking and Finance, 24(2): 1933-57.

Sabirianova Klara, Jan Svejnar, and Katherine Terrell. 2005. "Foreign Investment, Corporate Ownership, and Development: Are Firms in Emerging Markets Catching Up to the World Standard?” William Davidson Institute Working 734.

Salis, Sergio. 2006. "Evaluating the Causal Effect of Foreign Acquisition on Domestic Performances: The Case of Slovenian Manufacturing Firms.” William Davidson Institute Working Paper 803.

Shirley, Mary, and Patrick Walsh. 2001. "Public versus Private Ownership: The Current State of the Debate.” World Bank Policy Research Paper 2420.

Shleifer, Andrei, and Daniel Treisman. 2005. “A Normal Country: Russia after Communism.” The Journal of Economic Perspectives, 19(1): 151-174.

Shleifer, Andrei, and Robert W. Vishny. 1994. "Politicians and Firms.” Quarterly Journal of Economics, 109:4: 995-1025.

Shleifer, Andrei, and Robert W. Vishny. 1997. “A Survey of Corporate Governance.” Journal of Finance, 52(2): 737-83.

Simoneti, Marko, Joze P. Damijan, Matija Rojec, and Boris Majcen. 2005. "Case-bycase versus Mass Pprivatization in Transition Economies: Initial Owner and Final Seller Effects on Performance of Firms in Slovenia.” World Development, 33(10): 1603-25.

Simoneti, Marko, and Aleksandra Gregoric. 2004. "Managerial Ownership and Corporate Performance in Slovenian Post-privatisation Period.” European Journal of Comparative Economics, 1(2): 217-41. 
Smith, Stephen, Beom-Cheol Cin, and Milan Vodopivec. 1997. "Privatization Incidence, ownership Forms, and Firm Performance: Evidence from Slovenia." Journal of Comparative Economics, 25: 158-179.

Song, Ligang, and Yang Yao. 2004. "Impacts of Privatization on Firm Performance in China.” China Center for Economic Research Working Paper E2004005.

Stiglitz, Joseph. 2002. Globalization and its Discontents. New York: Norton.

Sun, Qian, and Wilson H. S. Tong. 2003. "China share issue privatization: the extent of its success.” Journal of Financial Economics, 70(2): 183-222.

Svejnar, Jan. 1989. "A Framework for the Economic Transformation of Czechoslovakia.” PlanEcon Report, 5(52): 1-18.

Svejnar, Jan. 1991. "Microeconomic Issues in the Transition to a Market Economy." Journal of Economic Perspectives, 5(4): 123-38.

Svejnar, Jan. 2002a. "Transition Economies: Performance and Challenges," Journal of Economic Perspectives, 16(1): 3-28.

Tian, Lihui, and Saul Estrin. 2005. "Retained State Shareholding in Chinese PLCs: Does Government Ownership Reduce Corporate Value?” William Davidson Institute Working Paper 750.

Tian, Xiaowen. 2001. "Privatization and Economic Performance: Evidence from Chinese Provinces.” Economic Systems, 25(1): 65-77.

Vickers, John, and George Yarrow. 1988. Privatization: An Economic Analysis. Cambridge, MA: MIT Press.

Vining, Aidan R., and Anthony E. Boardman. 1992. "Ownership versus Competition: Efficiency in Public Enterprise.” Public Choice, 73(2): 205-39.

Xu, Xiaonian, and Yan Wang. 1999. "Ownership Structure and Corporate Governance in Chinese Stock Companies.” China Economic Review, 10: 75-98.

Wang, Changyun. 2005. "Ownership and operating performance of Chinese IPOs." Journal of Banking and Finance, 29, 1835-56.

Walsh, Patrick P., and Ciara Whelan. 2001. "Firm Performance and the Political Economy of Corporate Governance: Survey Evidence for Bulgaria, Hungary, Slovakia and Slovenia.” Economic Systems 25(2): 85-112.

Warzynski, Frederic. 2003. "Managerial Change, Competition, and Privatization in Ukraine.” Journal of Comparative Economics, 31(2): 297-314. 
Wei, Zuobao, Oscar A. Varela, and M. Kabir Hassan. 2002. "Ownership and Performance in Chinese Manufacturing Industry" Journal of Multinationa Financial Management, 12(1): 61-78.

Wei, Zuobao, Oscar A. Varela, Juliet D'Souza, and M. Kabir Hassan. 2003. "The Financial and Operating Performance of China's Newly Privatized Firms” Financial Management, 32(2):107-126.

Wei, Zuobao, Oscar A. Varela. 2003. "State equity ownership and firm market performance: evidence from China's newly privatized firms.” Global Finance Journal, 14(1): 65-82.

Wei, Zuobao, Feixue Xie, and Shaorong Zhang. 2005. “Ownership Structure and Firm Value in China's Privatized Firms: 1991-2001”. Journal of Financial and Quantitative Analysis, 40(1), 87-108.

Weiss, Andrew, and Georgiy Nikitin. 2002. "Effects of Ownership by Investment Funds on the Performance of Czech Firms" in Designing Financial Systems in Transition Economies: Strategies for Reform in Central and Eastern Europe, ed. Anna Meyendorff and Anjan V. Thakor. Cambridge, MA: MIT Press.

World Bank. 1996. World Development Report- From Plan to Market. New York: Oxford University Press.

Yusuf, Shahid; Nabeshima, Kaoru and Perkins, Dwight H. 2006. Under New Ownership: Privatizing China's State-owned Enterprises. Washington, DC: world Bank.

Zalduendo, Juan. 2003. "Enterprise Restructuring and Transition: Evidence from the Former Yugoslav Republic Macedonia.” International Monetary Fund Working Paper 03/136.

Zemplinerova, Alena, Radek Lasovicka, and Anton Marcincin. 1995. Restructuring of Czech Manufacturing Enterprises: An Empirical Study.” CERGE-EI Working Paper 74.

Zinnes, Clifford, Yair Eilat, and Jeffrey Sachs. 2001. "The Gains from Privatization in Transition Economies: Is Change of Ownership Enough?” IMF Staff Papers 48(0): 14670. 
TABLE 1: PRIVATE SECTOR SHARE OF GDP

\begin{tabular}{|c|c|c|c|c|c|c|c|c|c|c|c|c|c|c|c|c|c|}
\hline & 1990 & 1991 & 1992 & 1993 & 1994 & 1995 & 1996 & 1997 & 1998 & 1999 & 2000 & 2001 & 2002 & 2003 & 2004 & 2005 & 2006 \\
\hline Czech Republic & 10 & 15 & 30 & 45 & 65 & 70 & 75 & 75 & 75 & 80 & 80 & 80 & 80 & 80 & 80 & 80 & 80 \\
\hline Hungary & 25 & 30 & 40 & 50 & 55 & 60 & 70 & 75 & 80 & 80 & 80 & 80 & 80 & 80 & 80 & 80 & 80 \\
\hline Poland & 30 & 40 & 45 & 50 & 55 & 60 & 60 & 65 & 65 & 65 & 70 & 75 & 75 & 75 & 75 & 75 & 75 \\
\hline Slovak Republic & 10 & 15 & 30 & 45 & 55 & 60 & 70 & 75 & 75 & 75 & 80 & 80 & 80 & 80 & 80 & 80 & 80 \\
\hline Slovenia & 15 & 20 & 30 & 40 & 45 & 50 & 55 & 60 & 60 & 60 & 65 & 65 & 65 & 65 & 65 & 65 & 65 \\
\hline Estonia & 10 & 10 & 25 & 40 & 55 & 65 & 70 & 70 & 70 & 75 & 75 & 75 & 80 & 80 & 80 & 80 & 80 \\
\hline Latvia & 10 & 10 & 25 & 30 & 40 & 55 & 60 & 60 & 65 & 65 & 65 & 65 & 70 & 70 & 70 & 70 & 70 \\
\hline Lithuania & 10 & 10 & 20 & 35 & 60 & 65 & 70 & 70 & 70 & 70 & 70 & 70 & 75 & 75 & 75 & 75 & 75 \\
\hline Bulgaria & 10 & 20 & 25 & 35 & 40 & 50 & 55 & 60 & 65 & 70 & 70 & 70 & 70 & 75 & 75 & 75 & 75 \\
\hline Romania & 15 & 25 & 25 & 35 & 40 & 45 & 55 & 60 & 60 & 60 & 60 & 65 & 65 & 65 & 70 & 70 & 70 \\
\hline Russia & 5 & 5 & 25 & 40 & 50 & 55 & 60 & 70 & 70 & 70 & 70 & 70 & 70 & 70 & 70 & 65 & 65 \\
\hline Ukraine & 10 & 10 & 10 & 15 & 40 & 45 & 50 & 55 & 55 & 55 & 60 & 60 & 65 & 65 & 65 & 65 & 65 \\
\hline
\end{tabular}


TABLE 2: EFFECT OF OWNERSHIP ON TOTAL FACTOR PRODUCTIVITY

\begin{tabular}{|c|c|c|c|c|c|c|c|c|}
\hline Category & Author(s) & $\begin{array}{c}\text { Country / region, period, } \\
\text { observations }\end{array}$ & $\begin{array}{c}\text { Dependent } \\
\text { variable }\end{array}$ & \multicolumn{4}{|c|}{ Ownership } & Effect \\
\hline \multicolumn{9}{|c|}{ PANEL A } \\
\hline \multirow{6}{*}{1} & \multirow{6}{*}{ Andreyeva (2003) } & \multirow{6}{*}{$\begin{array}{c}\text { Ukraine; } \\
1996-2000 ; \mathrm{N}=3909 \text { or } 3497\end{array}$} & \multirow{6}{*}{$\log (\mathrm{TP})$} & Private & & & All & Positive** \\
\hline & & & & State & & & Monopoly & Positive** \\
\hline & & & & & & Maj. & & Positive*** \\
\hline & & & & Private & & & Small & $\mathrm{N} / \mathrm{S}$ \\
\hline & & & & & & & Large Outsider & Positive* \\
\hline & & & & & & & Large Insider & $\mathrm{N} / \mathrm{S}$ \\
\hline \multirow{6}{*}{1} & \multirow{6}{*}{$\begin{array}{l}\text { Angelucci, Estrin, Konings, } \\
\text { Zolkiewski (2002) }\end{array}$} & \multirow{2}{*}{$\begin{array}{c}\text { Romania; } \\
\text { 1997-1998; N = } 2942\end{array}$} & \multirow{2}{*}{ VA } & Private & & Maj. & & $\mathrm{N} / \mathrm{S}$ \\
\hline & & & & Private & For. & Maj. & & $\mathrm{N} / \mathrm{S}$ \\
\hline & & Bulgaria; & \multirow{2}{*}{ VA } & Private & & Maj. & & Positive** \\
\hline & & $1997-1998 ; \mathrm{N}=1984$ & & Private & For. & Maj. & & Positive** \\
\hline & & Poland; & \multirow{2}{*}{ VA } & Private & & Maj. & & Positive** \\
\hline & & $1997-1998 ; \mathrm{N}=17570$ & & Private & For. & Maj. & & Positive** \\
\hline \multirow{2}{*}{1} & \multirow{2}{*}{ Brown and Earle (2001a) } & Russia; & \multirow{2}{*}{$\log (\mathrm{TP})$} & Private & & & & Positive*** \\
\hline & & $1992-1999 ; \mathrm{N}=79343$ & & & & Maj. & & Positive*** \\
\hline 1 & Brown and Earle (2001b) & $\begin{array}{c}\text { Russia; } \\
1992-1999 ; \mathrm{N}=77122\end{array}$ & $\log (\mathrm{TP})$ & Private & & & & Positive* \\
\hline \multirow{12}{*}{1} & \multirow{12}{*}{$\begin{array}{l}\text { Brown, Earle and Telegdy } \\
\text { (2006) }\end{array}$} & \multirow{12}{*}{$\begin{array}{c}\text { Hungary, Romania, Russia, } \\
\text { Ukraine }\end{array}$} & \multirow{12}{*}{$\log$ (Multif.P) } & Private & & Maj. & Hungary & Positive*** \\
\hline & & & & Private & & Maj. & Romania & Positive*** \\
\hline & & & & Private & & Maj. & Russia & Negative*** \\
\hline & & & & Private & & Maj. & Ukraine & Positive*** \\
\hline & & & & Private & For. & Maj. & Hungary & Positive*** \\
\hline & & & & Private & Dom. & Maj. & Hungary & Positive*** \\
\hline & & & & Private & For. & Maj. & Romania & Positive*** \\
\hline & & & & Private & Dom. & Maj. & Romania & Positive*** \\
\hline & & & & Private & For. & Maj. & Russia & Positive*** \\
\hline & & & & Private & Dom. & Maj. & Russia & Negative*** \\
\hline & & & & Private & For. & Maj. & Ukraine & Positive*** \\
\hline & & & & Private & Dom. & Maj. & Ukraine & Positive** or N/S \\
\hline 1 & $\begin{array}{c}\text { Claessens and Djankov } \\
\text { (1998) }\end{array}$ & $\begin{array}{l}7 \text { East European countries; } \\
\text { 1992-1995; } \mathrm{N}=19062\end{array}$ & $\% \Delta$ in $\log (\mathrm{TP})$ & Private & & & & Positive** \\
\hline \multirow{3}{*}{1} & \multirow{3}{*}{$\begin{array}{l}\text { Commander and Svejnar } \\
\qquad(2007)\end{array}$} & \multirow{3}{*}{$\begin{array}{c}26 \text { countries; } \\
2002 \text { and } 2005 ; N=5752-8967\end{array}$} & \multirow{3}{*}{ VA } & Private & & & Privatized & $\mathrm{N} / \mathrm{S}$ \\
\hline & & & & Private & & & DeNovo & $\mathrm{N} / \mathrm{S}$ \\
\hline & & & & Private & For. & & & Positive** \\
\hline \multirow{2}{*}{1} & \multirow{2}{*}{$\begin{array}{l}\text { Jones, Klinedinst and Rock } \\
\text { (1998) }\end{array}$} & \multirow{2}{*}{$\begin{array}{c}\text { Bulgaria; } \\
\text { 1989-1992; } \mathrm{N}=741\end{array}$} & \multirow{2}{*}{$\log (\mathrm{VA})$} & Private & & & & Positive $* * *$ \\
\hline & & & & Collective & & & & $\mathrm{N} / \mathrm{S}$ \\
\hline
\end{tabular}


TABLE 2: EFFECT OF OWNERSHIP ON TOTAL FACTOR PRODUCTIVITY

\begin{tabular}{|c|c|c|c|c|c|c|c|c|}
\hline Category & Author(s) & $\begin{array}{c}\text { Country / region, period, } \\
\text { observations }\end{array}$ & Dependent & \multicolumn{4}{|c|}{ Ownership } & \multirow{2}{*}{$\frac{\text { Effect }}{\text { Negative* }^{*}}$} \\
\hline \multirow{3}{*}{1} & \multirow{3}{*}{$\begin{array}{l}\text { Orazem and Vodopivec } \\
\qquad(2004)\end{array}$} & \multirow{3}{*}{$\begin{array}{c}\text { Slovenia; } \\
\text { 1994-2001; } \mathrm{N}=27949\end{array}$} & \multirow{3}{*}{$\log (\mathrm{TP})$} & Private & & & Limited Liab. & \\
\hline & & & & Private & & & & $\mathrm{N} / \mathrm{S}$ \\
\hline & & & & Private & For. & & & $\mathrm{N} / \mathrm{S}$ \\
\hline \multirow{3}{*}{1} & \multirow{3}{*}{ Pivovarsky (2003) } & \multirow{3}{*}{$\begin{array}{c}\text { Ukraine; } \\
1998 ; \mathrm{N}=361\end{array}$} & \multirow{3}{*}{ TFT estimate } & State & & Blk. Min. & & $\mathrm{N} / \mathrm{S}$ \\
\hline & & & & State & & Maj. & & $\mathrm{N} / \mathrm{S}$ \\
\hline & & & & Private & & & & Positive** \\
\hline \multirow{6}{*}{1} & \multirow{6}{*}{$\begin{array}{l}\text { Sabirianova, Svejnar, and } \\
\text { Terrell (2005) }\end{array}$} & \multirow{3}{*}{$\begin{array}{c}\text { Czech Republic; } \\
\text { 1992-2000; N = } 19971\end{array}$} & \multirow{3}{*}{ VA } & Private & Dom. & & & Positive** \\
\hline & & & & Mixed & & & & Positive** \\
\hline & & & & Private & For. & & & Positive** \\
\hline & & \multirow{3}{*}{$\begin{array}{c}\text { Russia; } \\
\text { 1992-2000; } \mathrm{N}=26286\end{array}$} & \multirow{3}{*}{ VA } & Private & Dom. & & & Positive** \\
\hline & & & & Mixed & & & & Negative** \\
\hline & & & & Private & For. & & & Negative** \\
\hline 1 & Salis (2006) & $\begin{array}{c}\text { Slovenian manufacturing firms; } \\
1996-1999 ; \mathrm{N}=980\end{array}$ & $\log (\mathrm{TFP})$ & Private & For. & & Acquisition & Positive** \\
\hline \multirow{2}{*}{1} & \multirow{2}{*}{$\begin{array}{c}\text { Simoneti, Damijan, Rojec, } \\
\text { Majcen (2005) }\end{array}$} & \multirow{2}{*}{$\begin{array}{c}\text { Slovenia; } \\
\text { 1994-2001; } N=479\end{array}$} & \multirow{2}{*}{ growth TFP } & & & & List. & Positive*** \\
\hline & & & & & & & Non-List. & $\mathrm{N} / \mathrm{S}$ \\
\hline \multirow{2}{*}{1} & \multirow{2}{*}{$\begin{array}{c}\text { Smith, Cin, and Vodopivec } \\
\text { (1997) }\end{array}$} & \multirow{2}{*}{$\begin{array}{c}\text { Slovenia; } \\
\text { 1989-1992; } \mathrm{N}=3729\end{array}$} & \multirow{2}{*}{$\log (\mathrm{VA})$} & Worker & & & & $\mathrm{N} / \mathrm{S}$ \\
\hline & & & & & For. & & & Positive** \\
\hline \multirow{2}{*}{2} & \multirow{2}{*}{$\begin{array}{l}\text { Grosfeld and Tressel } \\
(2002)\end{array}$} & \multirow{2}{*}{$\begin{array}{c}\text { Poland; } \\
\text { 1991-1998; } \mathrm{N}=493\end{array}$} & $0 \wedge$ in $\log ($ TP) & Private & & Min. & & Negative $* * *$ \\
\hline & & & $\% \Delta$ in $\log (1 P)$ & Private & & Maj. & & Positive** \\
\hline & & & & Mngmnt. & & & Initial & $\mathrm{N} / \mathrm{S}$ \\
\hline & & & & Mngmnt. & & & Final & $\mathrm{N} / \mathrm{S}$ \\
\hline & & & & Mngmnt. & & & List. & $\mathrm{N} / \mathrm{S}$ \\
\hline & & & & Mngmnt. & & & Non-List. & $\mathrm{N} / \mathrm{S}$ \\
\hline & & & & Mngmnt. & & Dispersed & & $\mathrm{N} / \mathrm{S}$ \\
\hline & & & & Mngmnt. & & Min. & & $\mathrm{N} / \mathrm{S}$ \\
\hline & & & & Mngmnt. & & Blk. Min. & & $\mathrm{N} / \mathrm{S}$ \\
\hline 2 & Simoneti Greooric (2004) & Slovenia; & $\% \Delta$ in $\log (T P)$ & Mngmnt. & & Maj. & & $\mathrm{N} / \mathrm{S}$ \\
\hline 2 & simonet1, Gregoric (2004) & $1995-1999 ; \mathrm{N}=182$ & $\% \Delta$ in $\log (1 P)$ & Insider & & & Initial & $\mathrm{N} / \mathrm{S}$ \\
\hline & & & & Insider & & & Final & $\mathrm{N} / \mathrm{S}$ \\
\hline & & & & Insider & & & List. & $\mathrm{N} / \mathrm{S}$ \\
\hline & & & & Insider & & & Non-List. & $\mathrm{N} / \mathrm{S}$ \\
\hline & & & & Insider & & Dispersed & & Negative*** \\
\hline & & & & Insider & & Min. & & $\mathrm{N} / \mathrm{S}$ \\
\hline & & & & Insider & & Blk. Min. & & $\mathrm{N} / \mathrm{S}$ \\
\hline & & & & Insider & & Maj. & & $\mathrm{N} / \mathrm{S}$ \\
\hline
\end{tabular}


TABLE 2: EFFECT OF OWNERSHIP ON TOTAL FACTOR PRODUCTIVITY

\begin{tabular}{|c|c|c|c|c|c|c|c|c|}
\hline Category & Author(s) & $\begin{array}{c}\text { Country / region, period, } \\
\text { observations }\end{array}$ & $\begin{array}{c}\text { Dependent } \\
\text { variable }\end{array}$ & \multicolumn{4}{|c|}{ Ownership } & Effect \\
\hline \multirow{8}{*}{2} & \multirow{8}{*}{$\begin{array}{l}\text { Weiss and Nikitin (2002) } \\
\text { (1998 version available } \\
\text { only) }\end{array}$} & \multirow{8}{*}{$\begin{array}{l}\text { Czech Republic; } \\
\text { 1993-1996; N =746 }\end{array}$} & \multirow{8}{*}{$\% \Delta$ in $\mathrm{VA} / \mathrm{K}$} & Private & & & Fin. & Positive* \\
\hline & & & & Private & & & Fin. & $\mathrm{N} / \mathrm{S}$ \\
\hline & & & & State & & & & $\mathrm{N} / \mathrm{S}$ \\
\hline & & & & State & & & & Positive* \\
\hline & & & & Private & Dom. & & & $\mathrm{N} / \mathrm{S}$ \\
\hline & & & & Private & For. & & & $\mathrm{N} / \mathrm{S}$ \\
\hline & & & & Private & & & Industrial & $\mathrm{N} / \mathrm{S}$ \\
\hline & & & & Private & & & Fin. & $\mathrm{N} / \mathrm{S}$ \\
\hline \multirow{5}{*}{3} & \multirow{5}{*}{$\begin{array}{l}\text { Cull, Matesova and Shirley } \\
\text { (2002) }\end{array}$} & \multirow{5}{*}{$\begin{array}{l}\text { Czech Republic; } \\
\text { 1993-1996; N =624 }\end{array}$} & \multirow{5}{*}{$\% \Delta$ in $\mathrm{TP}$} & $\overline{\text { Private }}$ & For. & & & N/S \\
\hline & & & & Private & For. & Maj. & & Negative** \\
\hline & & & & Private & Dom. & Maj. & Fin. & Negative*** \\
\hline & & & & Private & & & & Negative $* * *$ \\
\hline & & & & State & & & & $\mathrm{N} / \mathrm{S}$ \\
\hline 3 & $\begin{array}{c}\text { Dobrinsky, Dochev, } \\
\text { Mashiah, Markov (2001) }\end{array}$ & $\begin{array}{c}\text { Bulgaria; } \\
\text { 1994-1996; } \mathrm{N}=7786\end{array}$ & $\log (\mathrm{VA})$ & State & & & & Negative*** \\
\hline \multirow{13}{*}{3} & \multirow[t]{13}{*}{$\begin{array}{l}\text { Dobrinsky, Nikolov, } \\
\text { Markov (2001) }\end{array}$} & $\begin{array}{c}\text { Bulgaria; } \\
\text { 1995-1997; } \mathrm{N}=5 \text { 945-6 } 158\end{array}$ & $\log ($ real VA) & State & & & & Negative*** \\
\hline & & \multirow{4}{*}{$\begin{array}{c}\text { Lithuania; } \\
1994 \text { and } 1995 ; N=295+318\end{array}$} & \multirow{4}{*}{$\log (\mathrm{VA})$} & Private & For. & & & $\mathrm{N} / \mathrm{S}$ \\
\hline & & & & Private & Dom. & & & $\mathrm{N} / \mathrm{S}$ \\
\hline & & & & Mngmnt. & & & & $\mathrm{N} / \mathrm{S}$ \\
\hline & & & & Worker & & & & $\mathrm{N} / \mathrm{S}$ \\
\hline & & \multirow{4}{*}{$\begin{array}{c}\text { Latvia; } \\
1994 \text { and } 1995 ; N=128+132\end{array}$} & \multirow{4}{*}{$\log (\mathrm{VA})$} & Private & For. & & & $\mathrm{N} / \mathrm{S}$ \\
\hline & & & & Private & Dom. & & & Positive*** \\
\hline & & & & Mngmnt. & & & & Positive*, N/S \\
\hline & & & & Worker & & & & $\mathrm{N} / \mathrm{S}$ \\
\hline & & \multirow{4}{*}{$\begin{array}{c}\text { Estonia; } \\
1994 \text { and } 1995 ; \mathrm{N}=620+511\end{array}$} & \multirow{4}{*}{$\log (\mathrm{VA})$} & Private & For. & & & Positive*** \\
\hline & & & & Private & Dom. & & & Positive***, N/S \\
\hline & & & & Mngmnt. & & & & $\mathrm{N} / \mathrm{S}$ \\
\hline & & & & Worker & & & & Positive*, N/S \\
\hline
\end{tabular}


TABLE 2: EFFECT OF OWNERSHIP ON TOTAL FACTOR PRODUCTIVITY

\begin{tabular}{|c|c|c|c|c|c|c|c|}
\hline Category & Author(s) & $\begin{array}{c}\text { Country / region, period, } \\
\text { observations }\end{array}$ & $\begin{array}{l}\text { Dependent } \\
\text { variable }\end{array}$ & \multicolumn{3}{|c|}{ Ownership } & Effect \\
\hline \multirow{3}{*}{3} & \multirow{3}{*}{$\begin{array}{l}\text { Pohl, Anderson, Claessens, } \\
\text { and Djankov (1997) }\end{array}$} & \multirow{3}{*}{$\begin{array}{c}\text { Bulgaria, Czech Republic, } \\
\text { Hungary, Poland, Romania, } \\
\text { Slovenia, Slovakia; } \\
\text { 1992-1995, N=6 } 354 \\
\end{array}$} & \multirow{3}{*}{$\% \Delta$ in TP } & Private & & 1st year & Negative** \\
\hline & & & & Private & & 2nd year & Positive** \\
\hline & & & & Private & & 3rd year & Positive** \\
\hline \multicolumn{8}{|c|}{ PANEL B } \\
\hline \multirow{8}{*}{2} & \multirow{8}{*}{$\begin{array}{l}\text { Dong, Putterman and Unel } \\
\text { (2006) }\end{array}$} & \multirow{8}{*}{$\begin{array}{l}\text { Nanjing metropolitan area; } \\
\text { 1994-2001; } N=165\end{array}$} & \multirow{4}{*}{ growth of TFP } & State & & Urban & Positive** \\
\hline & & & & Private & & Urban & $\mathrm{N} / \mathrm{S}$ \\
\hline & & & & State & & Rural & $\mathrm{N} / \mathrm{S}$ \\
\hline & & & & Private & & Rural & $\mathrm{N} / \mathrm{S}$ \\
\hline & & & \multirow{4}{*}{$\begin{array}{l}\text { growth of } \\
\text { VA/Worker }\end{array}$} & State & & Urban & Positive** \\
\hline & & & & Private & & Urban & $\mathrm{N} / \mathrm{S}$ \\
\hline & & & & State & & Rural & $\mathrm{N} / \mathrm{S}$ \\
\hline & & & & Private & & Rural & $\mathrm{N} / \mathrm{S}$ \\
\hline \multirow[t]{3}{*}{2} & \multirow[t]{3}{*}{ Hu, Song, Zhang (2004) } & \multirow{3}{*}{$\begin{array}{c}\text { Beijing, Chongqing, } \\
\text { Guangzhou, Shanghai, Wuhan; } \\
\text { 1996-2001; N =736 }\end{array}$} & \multirow[t]{3}{*}{ TFP } & Private & & \begin{tabular}{|c|} 
Private- \\
ownership share \\
$(\%)$
\end{tabular} & Positive* \\
\hline & & & & Private & For. & & Positive** \\
\hline & & & & Coop. & & & Positive** \\
\hline \multirow{2}{*}{2} & \multirow{2}{*}{ Jefferson and $\mathrm{Su}(2006)$} & \multirow{2}{*}{$\begin{array}{c}1995 \& 2001 \\
N=20749\end{array}$} & $\mathrm{VA} / \mathrm{K}$ & Private & & Joint Stock & Positive*** \\
\hline & & & $\mathrm{VA} / \mathrm{L}$ & Private & & Joint Stock & Positive*** \\
\hline \multirow{5}{*}{3} & \multirow{5}{*}{$\begin{array}{l}\text { Dougherty and McGuckin } \\
\qquad(2002)\end{array}$} & \multirow{5}{*}{$1995 ; \mathrm{N}=20092$} & \multirow{5}{*}{$\log$ (Output) } & Collective & & & Positive*** \\
\hline & & & & Private & & Industrial & Positive*** \\
\hline & & & & Private & & Fin. & Positive*** \\
\hline & & & & Private & For. & Joint Venture & Positive*** \\
\hline & & & & Private & For. & $\begin{array}{l}\text { Pure foreign- } \\
\text { owned }\end{array}$ & Positive*** \\
\hline 3 & Li and $\mathrm{Wu}(2002)$ & $\begin{array}{c}\text { Jilin, Jiangsu, Shanxi, Sichuan; } \\
\text { 1980-1994; N = } 4414\end{array}$ & $\log (\mathrm{TP})$ & State & & $\begin{array}{l}\text { Ownership } \\
\text { fraction }\end{array}$ & Positive*** \\
\hline
\end{tabular}

$* * *=$ statistical significance at $1 \%$ level; $* *=$ statistical significance at $5 \%$ level; $*=$ statistical significance at $10 \%$ level;

$\mathrm{N} / \mathrm{S}=$ insignificant effect; Positive/Negative $=$ positive/negative effect

Private $=$ Private ownership $;$ State $=$ State ownership $;$ Worker $=$ Worker ownership $;$ Mngmnt. $=$ Manager ownership

Dom. $=$ Domestic ownershp; For. = Foreign ownership; Maj. = Majority control; Min. = Minority control; Blk. Min. = Blocking minority control

Fin. = Financial; Industrial=Ownership by Industrial firm; Mixed = Mixed ownership; Outsider = Outsider ownership; Insider = Insider Ownership;

List. $=$ Listed; Non-List. $=$ Non-Listed; Small = Small firms; Med. \& Lrg. = Medium \& Large firms; De Novo = New firms

Yr. Private $=$ Year privatized; Sub. Yrs. $=$ Subsequent years; Local $=$ Local government control

Urban = Urban firms; Rural = Rural firms; Joint = joint venture or joint stock companies; Coop. $=$ Cooperative 
TABLE 3: EFFECT OF OWNERSHIP ON LABOR PRODUCTIVITY

\begin{tabular}{|c|c|c|c|c|c|c|c|c|}
\hline Category & Author(s) & $\begin{array}{c}\text { Country / region, period, } \\
\text { observations }\end{array}$ & $\begin{array}{c}\text { Dependent } \\
\text { variable }\end{array}$ & \multicolumn{4}{|c|}{ Ownership } & Effect \\
\hline \multicolumn{9}{|c|}{ PANEL A } \\
\hline \multirow{6}{*}{1} & \multirow{6}{*}{$\begin{array}{l}\text { Claessens and Djankov } \\
\text { (1999) }\end{array}$} & \multirow{6}{*}{$\begin{array}{c}\text { Czech Republic; } \\
\text { 1992-1997; N = } 2860\end{array}$} & \multirow{6}{*}{$\mathrm{VA} / \mathrm{L}$} & Private & & & Fin. (bank) & $\mathrm{N} / \mathrm{S}$ \\
\hline & & & & Private & & & Fin. (non-bank) & Positive*** \\
\hline & & & & Private & Dom. & & Fin. & $\mathrm{N} / \mathrm{S}$ \\
\hline & & & & Private & For. & & Fin. & $\mathrm{N} / \mathrm{S}$ \\
\hline & & & & Private & & Maj. & Fin. & $\mathrm{N} / \mathrm{S}$ \\
\hline & & & & Private & & & 1st phase & Positive*** \\
\hline \multirow{3}{*}{1} & \multirow{3}{*}{$\begin{array}{l}\text { Claessens and Djankov } \\
\qquad(2002)\end{array}$} & \multirow{3}{*}{$\begin{array}{l}7 \text { East European countries; } \\
1992-1995 ; \mathrm{N}=6354\end{array}$} & \multirow{3}{*}{$\% \Delta$ in $\mathrm{SR} / \mathrm{L}$} & Private & & & In 1994 & $\mathrm{~N} / \mathrm{S}$ \\
\hline & & & & Private & & & In 1993 & $\mathrm{~N} / \mathrm{S}$ \\
\hline & & & & Private & & & Pre-1992 & Positive*** \\
\hline \multirow{2}{*}{1} & \multirow{2}{*}{ Earle and Telegdy (2002) } & \multirow{2}{*}{$\begin{array}{c}\text { Romania; } \\
\text { 1992-1997; } \mathrm{N}=14,532 \\
\end{array}$} & \multirow{2}{*}{$\mathrm{SR} / \mathrm{L}$} & State & & & & Positive*** \\
\hline & & & & Private & & & & Positive*** \\
\hline 1 & Grigorian (2000) & $\begin{array}{c}\text { Lithuania; } \\
1995-1997 ; \mathrm{N}=618\end{array}$ & $\log (\mathrm{SR} / \mathrm{L})$ & Private & & & & Positive*** \\
\hline \multirow{6}{*}{1} & \multirow{6}{*}{$\begin{array}{l}\text { Hanousek, Kocenda, and } \\
\text { Svejnar (2007) }\end{array}$} & \multirow{6}{*}{$\begin{array}{c}\text { Czech Republic; } \\
\text { 1996-1999; N = } 2949\end{array}$} & \multirow{6}{*}{$\begin{array}{c}\% \Delta \text { in Labor } \\
\text { Cost }\end{array}$} & Private & Dom. & & Industrial & Negative* \\
\hline & & & & Private & Dom. & & Fin. (non-bank) & Negative*** \\
\hline & & & & Private & Dom. & & Individual & $\mathrm{N} / \mathrm{S}$ \\
\hline & & & & Private & For. & & Industrial & Positive*** \\
\hline & & & & Private & For. & & Others & $\mathrm{N} / \mathrm{S}$ \\
\hline & & & & State & & Golden Share & & Positive*** \\
\hline 1 & Konings and Walsh (1999) & $\begin{array}{c}\text { Ukraine; } \\
1997 ; \mathrm{N}=258 \\
\end{array}$ & Productivity & Private & & & De Novo & Positive** \\
\hline \multirow{5}{*}{1} & \multirow{5}{*}{ Pivovarsky (2001) } & \multirow{5}{*}{$\begin{array}{c}\text { Ukraine; } \\
\text { 1998; } \mathrm{N}=361-374\end{array}$} & \multirow{5}{*}{$\mathrm{SR} / \mathrm{L}$} & State & & Blk. Min. & & $\mathrm{N} / \mathrm{S}$ \\
\hline & & & & State & & Maj. & & $\mathrm{N} / \mathrm{S}$ \\
\hline & & & & Private & & Maj. & & $\mathrm{N} / \mathrm{S}$ \\
\hline & & & & Private & For. & Maj. & & Positive*** \\
\hline & & & & Private & Dom. & Maj. & & $\mathrm{N} / \mathrm{S}$ \\
\hline 1 & $\begin{array}{l}\text { Perevalov, Gimadii, and } \\
\text { Dobrodey }(2000) \\
\end{array}$ & $\begin{array}{c}\text { Russia; } \\
\text { 1992-1996; } \mathrm{N}=945 \\
\end{array}$ & $\mathrm{SR} / \mathrm{L}$ & Private & & & & $\mathrm{N} / \mathrm{S}$ \\
\hline \multirow{2}{*}{2} & \multirow{2}{*}{$\begin{array}{c}\text { Carlin, Fries, Schaffer, } \\
\text { Seabright }(2001)\end{array}$} & \multirow{2}{*}{$\begin{array}{l}25 \text { transition countries; } \\
1996-1998 ; \mathrm{N}=2245\end{array}$} & \multirow{2}{*}{$\% \Delta$ in $\mathrm{TP} / \mathrm{L}$} & State & & & & $\mathrm{N} / \mathrm{S}$ \\
\hline & & & & & & & De Novo & Negative** \\
\hline \multirow{2}{*}{2} & \multirow{2}{*}{ Djankov (1999a) } & \multirow{2}{*}{$\begin{array}{l}\text { Georgia, Moldova; } \\
\text { 1995-1997; } \mathrm{N}=241\end{array}$} & $\mathrm{SR} / \mathrm{L}$ & Mngmnt. & & & & Positive** \\
\hline & & & $\mathrm{SK} / \mathrm{L}$ & & & & Voucher & \\
\hline
\end{tabular}


TABLE 3: EFFECT OF OWNERSHIP ON LABOR PRODUCTIVITY

\begin{tabular}{|c|c|c|c|c|c|c|c|}
\hline Category & Author(s) & $\begin{array}{c}\text { Country / region, period, } \\
\text { observations }\end{array}$ & $\begin{array}{c}\text { Dependent } \\
\text { variable }\end{array}$ & \multicolumn{3}{|c|}{ Ownership } & Effect \\
\hline \multirow{15}{*}{2} & \multirow{15}{*}{ Earle (1998) } & \multirow{15}{*}{$\begin{array}{c}\text { Russia; } \\
1994 ; \mathrm{N}=150-157\end{array}$} & \multirow{15}{*}{$\log (\mathrm{SR} / \mathrm{L})$} & Private & & & Positive*** \\
\hline & & & & Worker & & & $\mathrm{N} / \mathrm{S}$ \\
\hline & & & & Mngmnt. & & & $\mathrm{N} / \mathrm{S}$ \\
\hline & & & & Private & & Outsider & Positive*** \\
\hline & & & & Worker & & & $\mathrm{N} / \mathrm{S}$ \\
\hline & & & & Mngmnt. & & & $\mathrm{N} / \mathrm{S}$ \\
\hline & & & & & & Individuals & $\mathrm{N} / \mathrm{S}$ \\
\hline & & & & Private & & Fin. & Positive* \\
\hline & & & & Worker & & & $\mathrm{N} / \mathrm{S}$ \\
\hline & & & & Mngmnt. & & & $\mathrm{N} / \mathrm{S}$ \\
\hline & & & & & & Individuals & $\mathrm{N} / \mathrm{S}$ \\
\hline & & & & Private & & Fin. & $\mathrm{N} / \mathrm{S}$ \\
\hline & & & & Private & & Fin. & Positive* \\
\hline & & & & Private & Dom. & & $\mathrm{N} / \mathrm{S}$ \\
\hline & & & & Private & For. & Fin. & $\mathrm{N} / \mathrm{S}$ \\
\hline \multirow{10}{*}{2} & \multirow{10}{*}{$\begin{array}{l}\text { Frydman, Gray, Hessel, } \\
\text { and Rapaczynski (1999) }\end{array}$} & \multirow{10}{*}{$\begin{array}{l}\text { Hungary, Poland, Czech } \\
\text { Republic; } \\
\text { 1990-1993; N = } 466\end{array}$} & \multirow{10}{*}{ Revenues/L } & Private & & Dummy & $\mathrm{N} / \mathrm{S}$ \\
\hline & & & & Private & & Outsider & Positive** \\
\hline & & & & Private & & $\begin{array}{c}\text { Insider } \\
\text { ownership }\end{array}$ & $\mathrm{N} / \mathrm{S}$ \\
\hline & & & & Private & For. & Fin. & $\mathrm{N} / \mathrm{S}$ \\
\hline & & & & Private & Dom. & Fin. & Positive** \\
\hline & & & & Private & Dom. & & $\mathrm{N} / \mathrm{S}$ \\
\hline & & & & Private & Dom. & Individuals & $\mathrm{N} / \mathrm{S}$ \\
\hline & & & & State & & & $\mathrm{N} / \mathrm{S}$ \\
\hline & & & & Mngmnt. & & & $\mathrm{N} / \mathrm{S}$ \\
\hline & & & & Worker & & & $\mathrm{N} / \mathrm{S}$ \\
\hline 2 & Warzynski (2003) & $\begin{array}{c}\text { Ukraine; } \\
\text { 1989-1997; } \mathrm{N}=245\end{array}$ & $\% \Delta$ in TP & Private & & De Novo & Negative* \\
\hline \multirow{5}{*}{2} & \multirow{5}{*}{$\begin{array}{c}\text { Weiss and Nikitin (2002) } \\
\text { (1998 version available } \\
\text { only) }\end{array}$} & \multirow{5}{*}{$\begin{array}{c}\text { Czech Republic; } \\
\text { 1993-1996; N =697 }\end{array}$} & \multirow{5}{*}{$\mathrm{SR} / \mathrm{L}$} & State & & Gov. & Positive** \\
\hline & & & & Private & & Fin. & $\mathrm{N} / \mathrm{S}$ \\
\hline & & & & State & & Municip. & $\mathrm{N} / \mathrm{S}$ \\
\hline & & & & Private & Dom. & Industrial & $\mathrm{N} / \mathrm{S}$ \\
\hline & & & & Private & For. & Industrial & $\mathrm{N} / \mathrm{S}$ \\
\hline
\end{tabular}


TABLE 3: EFFECT OF OWNERSHIP ON LABOR PRODUCTIVITY

\begin{tabular}{|c|c|c|c|c|c|c|c|c|}
\hline Category & Author(s) & $\begin{array}{c}\text { Country / region, period, } \\
\text { observations }\end{array}$ & $\begin{array}{l}\text { Dependent } \\
\text { variable }\end{array}$ & \multicolumn{4}{|c|}{ Ownership } & Effect \\
\hline \multirow{4}{*}{3} & \multirow{4}{*}{$\begin{array}{l}\text { Akimova and Schwödiauer } \\
\text { (2000) }\end{array}$} & \multirow{4}{*}{$\begin{array}{c}\text { Ukraine; } \\
1993-1997 ; \mathrm{N}=164-173 \text { or } 56\end{array}$} & \multirow{4}{*}{$\% \Delta$ in $\mathrm{SR} / \mathrm{L}$} & Private & & & private & $\mathrm{N} / \mathrm{S}$ \\
\hline & & & & Private & & & Outsider & Positive** \\
\hline & & & & Private & & Maj. & Insider & $\mathrm{N} / \mathrm{S}$ \\
\hline & & & & Private & & Maj. & Insider & Positive** \\
\hline \multirow{6}{*}{3} & \multirow{6}{*}{$\begin{array}{l}\text { Akimova and Schwödiauer } \\
\text { (2004) }\end{array}$} & \multirow{6}{*}{$\begin{array}{c}\text { Ukraine; } \\
\text { 1998-2000; } \mathrm{N}=202\end{array}$} & \multirow{6}{*}{ S/Worker } & State & & & & $\mathrm{N} / \mathrm{S}$ \\
\hline & & & & Mngmnt. & & & & Positive* \\
\hline & & & & Worker & & & & Positive** \\
\hline & & & & Private & Dom. & & Outsider & $\mathrm{N} / \mathrm{S}$ \\
\hline & & & & Private & For. & & & Positive** $^{* *}$ \\
\hline & & & & Private & & & $\begin{array}{c}\text { Insider } \\
\text { ownership }\end{array}$ & Positive** \\
\hline \multirow{3}{*}{3} & \multirow{3}{*}{$\begin{array}{l}\text { Bakanova, Estrin, Pelipas } \\
\text { and Pukovic (2006) }\end{array}$} & \multirow{3}{*}{$\begin{array}{c}\text { Belarus; } \\
2004 ; \mathrm{N}=402\end{array}$} & \multirow{3}{*}{ S/Worker } & Private & & & De Novo & $\mathrm{N} / \mathrm{S}$ \\
\hline & & & & Private & & Min. & & $\mathrm{N} / \mathrm{S}$ \\
\hline & & & & Private & & Maj. & & Negative* \\
\hline \multirow{4}{*}{3} & \multirow{4}{*}{$\begin{array}{l}\text { Dean and Andreyeva } \\
\qquad(2001)\end{array}$} & \multirow{4}{*}{$\begin{array}{c}\text { Ukraine; } \\
\text { 1995-1998; } \mathrm{N}=190\end{array}$} & \multirow{4}{*}{$\log (\Delta$ labor $\mathrm{P})$} & State & & Min. & & $\mathrm{N} / \mathrm{S}$ \\
\hline & & & & State & & Blk. Min. & & $\mathrm{N} / \mathrm{S}$ \\
\hline & & & & Private & & Maj. & $\begin{array}{c}\text { Concentrated } \\
\text { ownership }\end{array}$ & Positive** \\
\hline & & & & Private & & & Insider & Positive** \\
\hline \multirow{6}{*}{3} & \multirow{6}{*}{ Djankov (1999b) } & \multirow{6}{*}{$\begin{array}{c}\text { Georgia, Moldova, Kazakhstan, } \\
\text { Kyrgyz, Russia, Ukraine; } \\
\text { 1995-1997; N = } 960\end{array}$} & \multirow{6}{*}{$\% \Delta$ in $\mathrm{SR} / \mathrm{L}$} & Mngmnt. & & & & $\mathrm{N} / \mathrm{S}$ \\
\hline & & & & Worker & & & & $\mathrm{N} / \mathrm{S}$ \\
\hline & & & & State & & & & $\mathrm{N} / \mathrm{S}$ \\
\hline & & & & Private & Dom. & & Outsider & $\mathrm{N} / \mathrm{S}$ \\
\hline & & & & Private & For. & & Outsider & $\mathrm{N} / \mathrm{S}$ \\
\hline & & & & & & & Individual & \\
\hline \multirow{3}{*}{3} & \multirow{3}{*}{ Earle and Estrin (1997) } & \multirow{3}{*}{$\begin{array}{c}\text { Russia; } \\
\text { 1990-1994; } \mathrm{N}=98-155\end{array}$} & \multirow{3}{*}{$\log (\mathrm{SR} / \mathrm{L})$} & Private & & & & Positive** \\
\hline & & & & Private & & & & Positive** \\
\hline & & & & Private & & & & Positive** \\
\hline 3 & Earle and Estrin (2003) & $\begin{array}{c}\text { Russia; } \\
1994 ; \mathrm{N}=119\end{array}$ & $\log (\mathrm{SR} / \mathrm{L})$ & Private & & & & Positive** \\
\hline
\end{tabular}


TABLE 3: EFFECT OF OWNERSHIP ON LABOR PRODUCTIVITY

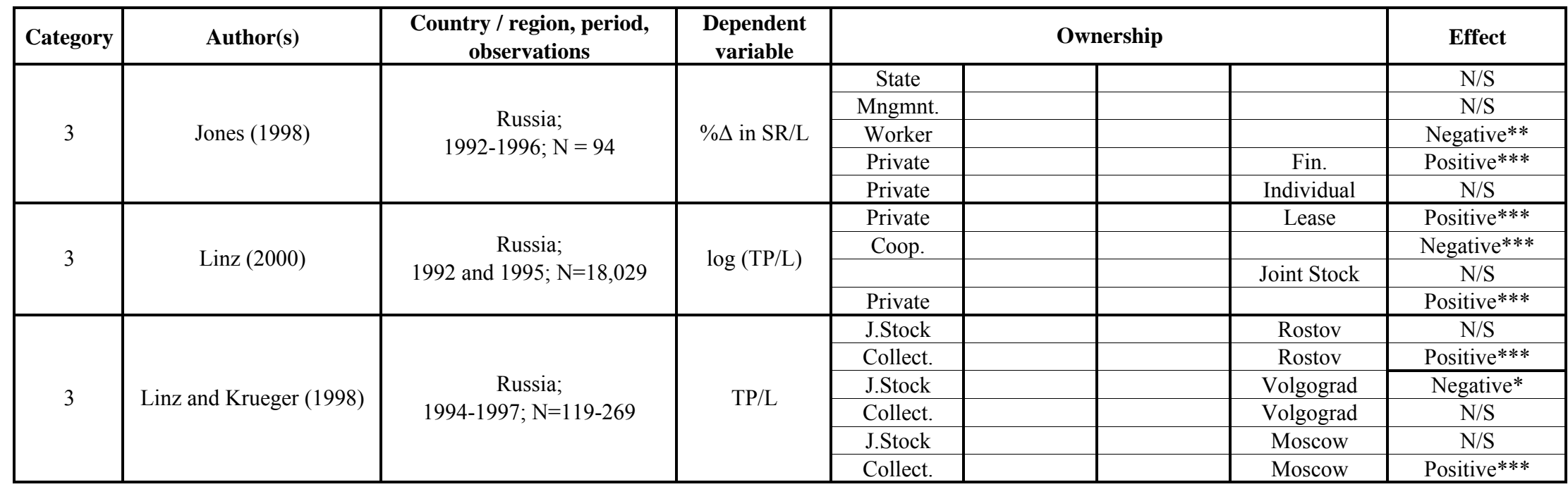

\begin{tabular}{|c|c|c|c|c|c|c|c|c|}
\hline \multicolumn{9}{|c|}{ PANEL B } \\
\hline \multirow{3}{*}{1} & \multirow{3}{*}{ Song and Yao (2004) } & \multirow{3}{*}{$\begin{array}{c}11 \text { cities: } \\
1995-2001 ; N=3290\end{array}$} & \multirow{3}{*}{ Productivity } & Private & & & & $\mathrm{N} / \mathrm{S}$ \\
\hline & & & & State & & Maj. & & $\mathrm{N} / \mathrm{S}$ \\
\hline & & & & Private & & Maj. & & $\mathrm{N} / \mathrm{S}$ \\
\hline \multirow{3}{*}{2} & \multirow{3}{*}{$\begin{array}{l}\mathrm{Hu} \text {, Song and Zhang } \\
\text { (2004) }\end{array}$} & \multirow{3}{*}{$\begin{array}{c}\text { Beijing, Chongqing, } \\
\text { Guangzhou, Shanghai, Wuhan; } \\
\text { 1996-2001; N =736 }\end{array}$} & \multirow{3}{*}{ VA/Worker } & Private & & & & Positive** \\
\hline & & & & Private & For. & & & $\mathrm{N} / \mathrm{S}$ \\
\hline & & & & $\begin{array}{l}\text { Coop. }+ \\
\text { Private }\end{array}$ & & & & $\mathrm{N} / \mathrm{S}$ \\
\hline 2 & Li and Rozelle (2004) & $1994-1997 ; \mathrm{N}=295$ & $\begin{array}{c}\log \\
\text { (VA/Worker) }\end{array}$ & State & & & $\begin{array}{c}\text { Govt. paper } \\
\text { share }\end{array}$ & $\mathrm{N} / \mathrm{S}$ \\
\hline \multirow{4}{*}{2} & \multirow{4}{*}{ Sun and Tong (2003) } & \multirow{4}{*}{$1994-1998 ; \mathrm{N}=634$} & $\begin{array}{l}\text { Number of } \\
\text { employees }\end{array}$ & State & & & Mixed & $\mathrm{N} / \mathrm{S}$ \\
\hline & & & $\begin{array}{l}\text { Real sales/ } \\
\text { Employees } \\
\end{array}$ & State & & & Mixed & $\mathrm{N} / \mathrm{S}$ \\
\hline & & & $\begin{array}{l}\text { Real net profir/ } \\
\text { Employees }\end{array}$ & State & & & Mixed & $\mathrm{N} / \mathrm{S}$ \\
\hline & & & $\begin{array}{l}\text { Real EBIT/ } \\
\text { Employees }\end{array}$ & State & & & Mixed & $\mathrm{N} / \mathrm{S}$ \\
\hline
\end{tabular}


TABLE 3: EFFECT OF OWNERSHIP ON LABOR PRODUCTIVITY

\begin{tabular}{|c|c|c|c|c|c|c|c|}
\hline Category & Author(s) & $\begin{array}{c}\text { Country / region, period, } \\
\text { observations }\end{array}$ & $\begin{array}{c}\text { Dependent } \\
\text { variable }\end{array}$ & \multicolumn{3}{|c|}{ Ownership } & Effect \\
\hline \multirow{8}{*}{2} & \multirow{8}{*}{$\begin{array}{l}\text { Yusuf, Nabeshima and } \\
\text { Perkins (2006) }\end{array}$} & \multirow{8}{*}{$1996-2001 ; \mathrm{N}=3577$} & \multirow{8}{*}{$\begin{array}{c}\log (\mathrm{VA} \\
\text { production) }\end{array}$} & Private & For. & $\begin{array}{c}\text { Ownership } \\
\text { share }\end{array}$ & $\mathrm{N} / \mathrm{S}$ \\
\hline & & & & State & & $\begin{array}{l}\text { Ownership } \\
\text { share }\end{array}$ & Negative*** \\
\hline & & & & State & Reformed & Joint Venture & Positive*** \\
\hline & & & & State & Reformed & Limited Liab. & Positive*** \\
\hline & & & & Private & For. & Joint Venture & Positive*** \\
\hline & & & & Private & & & $\mathrm{N} / \mathrm{S}$ \\
\hline & & & & Collective & & & $\mathrm{N} / \mathrm{S}$ \\
\hline & & & & Private & For. & \begin{tabular}{|c|}
$\begin{array}{c}\text { Wholly foreign- } \\
\text { owned }\end{array}$ \\
\end{tabular} & $\mathrm{N} / \mathrm{S}$ \\
\hline \multirow{5}{*}{3} & \multirow{5}{*}{ Li and Rozelle (2003) } & \multirow{5}{*}{$\begin{array}{l}\text { Jiangsu, Zhejiang; } \\
\text { 1993-1999; } \mathrm{N}=552\end{array}$} & \multirow{5}{*}{ VA/Worker } & Private & & & Positive** \\
\hline & & & & Private & & $\begin{array}{c}\text { Pre- } \\
\text { privatization }\end{array}$ & $\mathrm{N} / \mathrm{S}$ \\
\hline & & & & Private & & Premium paying & Positive*** \\
\hline & & & & Private & & Mod. Disct. & $\mathrm{N} / \mathrm{S}$ \\
\hline & & & & Private & & Heav. Disct. & $\mathrm{N} / \mathrm{S}$ \\
\hline \multirow{8}{*}{3} & \multirow{8}{*}{$\begin{array}{l}\text { Wei, Varela and Hassan } \\
\qquad(2002)\end{array}$} & \multirow{8}{*}{$1994 ; \mathrm{N}=1029-1031$} & \multirow{4}{*}{$\begin{array}{l}\text { Net income/ } \\
\text { Worker }\end{array}$} & Coop. & & & Positive*** \\
\hline & & & & Private & & Joint & Positive* \\
\hline & & & & Private & & Mixed & Positive*** \\
\hline & & & & Private & For. & & $\mathrm{N} / \mathrm{S}$ \\
\hline & & & \multirow{4}{*}{ Sales/Worker } & Coop. & & & $\mathrm{N} / \mathrm{S}$ \\
\hline & & & & Private & & Joint & $\mathrm{N} / \mathrm{S}$ \\
\hline & & & & Private & & Mixed & Positive*** \\
\hline & & & & Private & For. & & $\mathrm{N} / \mathrm{S}$ \\
\hline
\end{tabular}

$* * *=$ statistical significance at $1 \%$ level; $* *=$ statistical significance at $5 \%$ level; $*=$ statistical significance at $10 \%$ level;

$\mathrm{N} / \mathrm{S}=$ insignificant effect; Positive/Negative $=$ positive/negative effect

Private $=$ Private ownership; State $=$ State ownership; Worker $=$ Worker ownership $;$ Mngmnt. $=$ Manager ownership

Dom. $=$ Domestic ownershp; For. $=$ Foreign ownership; Maj. = Majority control; Min. = Minority control; Blk. Min. = Blocking minority control

Fin. = Financial; Industrial=Ownership by Industrial firm; Mixed = Mixed ownership; Outsider = Outsider ownership; Insider = Insider Ownership;

List. = Listed; Non-List. = Non-Listed; Small = Small firms; Med. \& Lrg. = Medium \& Large firms; De Novo = New firms

Yr. Private $=$ Year privatized; Sub. Yrs. $=$ Subsequent years; Local $=$ Local government control

Urban = Urban firms; Rural = Rural firms; Joint $=$ joint venture or joint stock companies; Coop. $=$ Cooperative

Pre $=$ Preprivatization; Post $=$ Postprivatization; Prem. $=$ Premium paying;

Mod. Disct. $=$ Moderately discounted Heav. Disct. $=$ Heavily discounted 
TABLE 4: EFFECT OF OWNERSHIP ON PROFITABILITY

\begin{tabular}{|c|c|c|c|c|c|c|c|c|}
\hline Category & Author(s) & $\begin{array}{c}\text { Country / region, period, } \\
\text { observations }\end{array}$ & $\begin{array}{l}\text { Dependent } \\
\text { variable }\end{array}$ & \multicolumn{4}{|c|}{ Ownership } & Effect \\
\hline \multicolumn{9}{|c|}{ PANEL A } \\
\hline \multirow{6}{*}{1} & \multirow{6}{*}{$\begin{array}{l}\text { Claessens and Djankov } \\
\text { (1999) }\end{array}$} & \multirow{6}{*}{$\begin{array}{c}\text { Czech Republic; } \\
\text { 1992-1997; N = } 2860\end{array}$} & \multirow{6}{*}{ Profitability } & Private & & Maj. & Fin. & $\mathrm{N} / \mathrm{S}$ \\
\hline & & & & Private & & & 1st phase & $\mathrm{N} / \mathrm{S}$ \\
\hline & & & & Private & & & $\begin{array}{l}\text { Fin. (Bank } \\
\text { Sponsored) }\end{array}$ & $\mathrm{N} / \mathrm{S}$ \\
\hline & & & & Private & & & Fin. & Positive*** \\
\hline & & & & Private & Dom. & & Fin. & Positive*** \\
\hline & & & & Private & For. & & Fin. & Positive*** \\
\hline \multirow{5}{*}{1} & \multirow{5}{*}{$\begin{array}{c}\text { Claessens, Djankov and } \\
\text { Pohl (1997) }\end{array}$} & \multirow{5}{*}{$\begin{array}{c}\text { Czech Republic; } \\
\text { 1992-1995; N = } 2490\end{array}$} & \multirow{5}{*}{ Profit } & Private & & & Fin. & $\mathrm{N} / \mathrm{S}$ \\
\hline & & & & Private & Dom. & & Fin. & Positive* \\
\hline & & & & Private & & & Fin. & $\mathrm{N} / \mathrm{S}$ \\
\hline & & & & State & & & & $\mathrm{N} / \mathrm{S}$ \\
\hline & & & & Private & For. & & Fin. & $\mathrm{N} / \mathrm{S}$ \\
\hline \multirow{14}{*}{1} & \multirow{14}{*}{$\begin{array}{l}\text { Hanousek, Kocenda, and } \\
\text { Svejnar (2007) }\end{array}$} & \multirow{14}{*}{$\begin{array}{c}\text { Czech Republic; } \\
\text { 1996-1999; N = } 2 \text { 168- } 2905\end{array}$} & \multirow{8}{*}{$\% \Delta$ in $\mathrm{ROA}$} & Private & Dom. & & Industrial & $\mathrm{N} / \mathrm{S}$ \\
\hline & & & & Private & Dom. & & $\begin{array}{l}\text { Subsequent } \\
\text { Ownership - } \\
\text { Fin. (Bank) }\end{array}$ & Positive** \\
\hline & & & & Private & Dom. & & $\begin{array}{l}\Delta \text { Ownership - } \\
\text { Fin. (Bank) }\end{array}$ & Negative*** \\
\hline & & & & Private & Dom. & & Individual & $\mathrm{N} / \mathrm{S}$ \\
\hline & & & & Private & For. & & Industrial & $\mathrm{N} / \mathrm{S}$ \\
\hline & & & & Private & For. & Blk. Min. & $\begin{array}{l}\text { Subsequent } \\
\text { Ownership }\end{array}$ & Positive* \\
\hline & & & & Private & For. & & Others & $\mathrm{N} / \mathrm{S}$ \\
\hline & & & & State & & Golden Share & & $\mathrm{N} / \mathrm{S}$ \\
\hline & & & \multirow{6}{*}{$\begin{array}{c}\% \Delta \text { in } \\
\text { Profit/Sales }\end{array}$} & Private & Dom. & & Industrial & $\mathrm{N} / \mathrm{S}$ \\
\hline & & & & Private & Dom. & & $\begin{array}{l}\text { Subsequent - } \\
\text { Fin.(Bank) }\end{array}$ & Positive* \\
\hline & & & & Private & Dom. & & Individual & $\mathrm{N} / \mathrm{S}$ \\
\hline & & & & Private & For. & & $\begin{array}{c}\text { Initial } \\
\text { Ownership - } \\
\text { Industrial } \\
\end{array}$ & Positive* \\
\hline & & & & Private & For. & & $\begin{array}{c}\text { Subsequent } \\
\text { Ownership - } \\
\text { Others }\end{array}$ & Negative $* * *$ \\
\hline & & & & State & & Golden Share & & $\mathrm{N} / \mathrm{S}$ \\
\hline
\end{tabular}


TABLE 4: EFFECT OF OWNERSHIP ON PROFITABILITY

\begin{tabular}{|c|c|c|c|c|c|c|c|c|}
\hline Category & Author(s) & $\begin{array}{c}\text { Country / region, period, } \\
\text { observations }\end{array}$ & $\begin{array}{c}\text { Dependent } \\
\text { variable }\end{array}$ & \multicolumn{4}{|c|}{ Ownership } & \multirow{2}{*}{$\frac{\text { Effect }}{\text { Positive** }}$} \\
\hline 1 & $\begin{array}{l}\text { Hanousek and Kocenda } \\
\text { (2003) }\end{array}$ & $\begin{array}{c}\text { Czech Republic; } \\
\text { 1993-1995; N = } 1348\end{array}$ & $\% \Delta$ in $\mathrm{ROA}$ & Private & For. & Maj. & & \\
\hline 1 & $\begin{array}{l}\text { Perevalov, Gimadii, and } \\
\text { Dobrodey (2000) }\end{array}$ & $\begin{array}{c}\text { Russia; } \\
\text { 1992-1996; N = } 945\end{array}$ & Profit margin & Private & & & & $\mathrm{N} / \mathrm{S}$ \\
\hline \multirow{2}{*}{1} & \multirow{2}{*}{ Warzynski (2003) } & \multirow{2}{*}{$\begin{array}{c}\text { Ukraine; } \\
\text { 1989-1997; } \mathrm{N}=238 \\
\end{array}$} & \multirow{2}{*}{$\begin{array}{c}\% \Delta \text { in } \\
\text { Profitability }\end{array}$} & Private & & & & $\mathrm{N} / \mathrm{S}$ \\
\hline & & & & Private & & & De Novo & $\mathrm{N} / \mathrm{S}$ \\
\hline \multirow{10}{*}{2} & \multirow{10}{*}{ Miller (2006) } & \multirow{10}{*}{$\begin{array}{c}\text { Bulgaria; } \\
\text { 1996-2003; } N=5360-5964\end{array}$} & \multirow{10}{*}{ ROA } & State & & Maj. & & Positive*** \\
\hline & & & & State & & Blk. Min. & & Positive** \\
\hline & & & & Private & & Maj. & & Positive** \\
\hline & & & & Private & & Blk. Min. & & $\mathrm{N} / \mathrm{S}$ \\
\hline & & & & Private & For. & & & Positive* \\
\hline & & & & Labor & & & & Positive** \\
\hline & & & & Private & & Maj. & Fin. & Positive** \\
\hline & & & & Private & & Blk. Min. & Fin. & Positive*** \\
\hline & & & & Private & & Min. & Hgh. Disp. & $\mathrm{N} / \mathrm{S}$ \\
\hline & & & & Private & & Min. & Lw. Disp. & $\mathrm{N} / \mathrm{S}$ \\
\hline \multirow{16}{*}{2} & \multirow{16}{*}{ Simoneti, Gregoric (2004) } & \multirow{16}{*}{$\begin{array}{c}\text { Slovenia; } \\
\text { 1995-1999; } \mathrm{N}=182\end{array}$} & \multirow{16}{*}{$\begin{array}{l}\text { EBITDA/ } \\
\text { Sales }\end{array}$} & Mngmnt. & & & Initial & $\mathrm{N} / \mathrm{S}$ \\
\hline & & & & Mngmnt. & & & Final & Positive* \\
\hline & & & & Mngmnt. & & & List. & $\mathrm{N} / \mathrm{S}$ \\
\hline & & & & Mngmnt. & & & Non-List. & Positive** \\
\hline & & & & Mngmnt. & & Dispersed & & $\mathrm{N} / \mathrm{S}$ \\
\hline & & & & Mngmnt. & & Min. & & Positive* \\
\hline & & & & Mngmnt. & & Blk. Min. & & Positive* \\
\hline & & & & Mngmnt. & & Maj. & & Positive* \\
\hline & & & & Insider & & & Initial & $\mathrm{N} / \mathrm{S}$ \\
\hline & & & & Insider & & & Final & $\mathrm{N} / \mathrm{S}$ \\
\hline & & & & Insider & & & List. & Negative* \\
\hline & & & & Insider & & & Non-List. & $\mathrm{N} / \mathrm{S}$ \\
\hline & & & & Insider & & Dispersed & & $\mathrm{N} / \mathrm{S}$ \\
\hline & & & & Insider & & Min. & & $\mathrm{N} / \mathrm{S}$ \\
\hline & & & & Insider & & Blk. Min. & & $\mathrm{N} / \mathrm{S}$ \\
\hline & & & & Insider & & Maj. & & $\mathrm{N} / \mathrm{S}$ \\
\hline
\end{tabular}


TABLE 4: EFFECT OF OWNERSHIP ON PROFITABILITY

\begin{tabular}{|c|c|c|c|c|c|c|c|c|}
\hline Category & Author(s) & $\begin{array}{c}\text { Country / region, period, } \\
\text { observations }\end{array}$ & $\begin{array}{l}\text { Dependent } \\
\text { variable }\end{array}$ & \multicolumn{4}{|c|}{ Ownership } & Effect \\
\hline \multirow{16}{*}{2} & \multirow{16}{*}{$\begin{array}{l}\text { Weiss and Nikitin (2002) } \\
\text { (1998 version available } \\
\text { only) }\end{array}$} & \multirow{16}{*}{$\begin{array}{c}\text { Czech Republic; } \\
\text { 1993-1996; } \mathrm{N}=697-746\end{array}$} & \multirow{8}{*}{$\begin{array}{l}\% \Delta \text { in } \\
\text { Profitability/ } \\
\text { Worker }\end{array}$} & Private & & & Fin. & $\mathrm{N} / \mathrm{S}$ \\
\hline & & & & Private & & & Fin. & $\mathrm{N} / \mathrm{S}$ \\
\hline & & & & State & & & Municip. & Positive*** \\
\hline & & & & State & & & Gov. & Positive** \\
\hline & & & & Private & Dom. & & Industrial & Positive*** \\
\hline & & & & Private & For. & & Industrial & $\mathrm{N} / \mathrm{S}$ \\
\hline & & & & Private & & & Industrial & $\mathrm{N} / \mathrm{S}$ \\
\hline & & & & Private & & & Fin. & $\mathrm{N} / \mathrm{S}$ \\
\hline & & & \multirow{8}{*}{$\begin{array}{l}\% \Delta \text { in } \\
\text { Profitability/ } \\
\text { Capital }\end{array}$} & Private & & & Fin. & Positive* \\
\hline & & & & Private & & & Fin. & $\mathrm{N} / \mathrm{S}$ \\
\hline & & & & State & & & Municip. & $\mathrm{N} / \mathrm{S}$ \\
\hline & & & & State & & & Gov. & Positive*,** \\
\hline & & & & Private & Dom. & & Industrial & Positive*,*** \\
\hline & & & & Private & For. & & Industrial & Positive** \\
\hline & & & & Private & & & Industrial & $\mathrm{N} / \mathrm{S}$ \\
\hline & & & & Private & & & Fin. & $\mathrm{N} / \mathrm{S}$ \\
\hline 2 & Zalduendo (2003) & $\begin{array}{c}\text { FYR Macedonia; } \\
\text { 1994, } 1997 \& 2000 ; N=2469\end{array}$ & Profit/Sales & Private & & & & Positive*** \\
\hline 3 & $\begin{array}{l}\text { Bakanova, Estrin, Pelipas } \\
\text { and Pukovic (2006) }\end{array}$ & $\begin{array}{c}\text { Belarus; } \\
2004 ; \mathrm{N}=402\end{array}$ & Profit/Sales & $\begin{array}{l}\text { Private } \\
\text { Private } \\
\text { Private }\end{array}$ & & $\begin{array}{l}\text { Min. } \\
\text { Maj. }\end{array}$ & De Novo & $\begin{array}{c}\mathrm{N} / \mathrm{S} \\
\mathrm{N} / \mathrm{S} \\
\text { Positive* }\end{array}$ \\
\hline 3 & Estrin and Rosevear (1999) & $\begin{array}{c}\text { Ukraine; } \\
1991-1997 ; \mathrm{N}=150 \\
\end{array}$ & Profit & Private & & & & $\mathrm{N} / \mathrm{S}$ \\
\hline 3 & $\begin{array}{l}\text { Lskavyan, Spatareanu } \\
\text { (2006) }\end{array}$ & $\begin{array}{c}\text { UK; 1999; } \mathrm{N}=411 \\
\text { Poland; 1999; } \mathrm{N}=87 \\
\text { Czech Republic; } 1999 ; \mathrm{N}=67\end{array}$ & ROA & $\begin{array}{l}\text { Private } \\
\text { Private } \\
\text { Private }\end{array}$ & $\begin{array}{l}\text { Dom. } \\
\text { Dom. } \\
\text { Dom. }\end{array}$ & & $\begin{array}{l}\text { Industrial } \\
\text { Industrial } \\
\text { Industrial }\end{array}$ & $\begin{array}{l}\mathrm{N} / \mathrm{S} \\
\mathrm{N} / \mathrm{S} \\
\mathrm{N} / \mathrm{S}\end{array}$ \\
\hline & & & PANEL & & & & & \\
\hline 1 & Jefferson and $\mathrm{Su}(2006)$ & $1995 \& 2001 ; N=20749$ & Profit/Sales & Private & & & Shares & Positive* \\
\hline \multirow{4}{*}{2} & \multirow{4}{*}{$\begin{array}{l}\text { Dong, Putterman and Unel } \\
\text { (2006) }\end{array}$} & \multirow{4}{*}{$\begin{array}{l}\text { Nanjing metropolitan area; } \\
1994-2001 ; N=165\end{array}$} & \multirow{4}{*}{ Profit/Sales } & State & & & Urban & Positive $* * *$ \\
\hline & & & & Private & & & Urban & $\mathrm{N} / \mathrm{S}$ \\
\hline & & & & State & & & Rural & $\mathrm{N} / \mathrm{S}$ \\
\hline & & & & Private & & & Rural & Positive*** \\
\hline
\end{tabular}


TABLE 4: EFFECT OF OWNERSHIP ON PROFITABILITY

\begin{tabular}{|c|c|c|c|c|c|c|c|c|}
\hline Category & Author(s) & $\begin{array}{c}\text { Country / region, period, } \\
\text { observations }\end{array}$ & $\begin{array}{c}\text { Dependent } \\
\text { variable }\end{array}$ & \multicolumn{4}{|c|}{ Ownership } & \multirow{2}{*}{$\begin{array}{c}\text { Effect } \\
\mathrm{N} / \mathrm{S}\end{array}$} \\
\hline \multirow{20}{*}{2} & \multirow{20}{*}{ Jia, Sun, Tong (2005) } & \multirow{20}{*}{$1993-2002 ; \mathrm{N}=530$} & \multirow{5}{*}{ Return on Sales } & State & & Min. & & \\
\hline & & & & State & & Maj. & & Negative** \\
\hline & & & & Private & & Min. & Legal & Positive** \\
\hline & & & & Private & & Maj. & Legal & $\mathrm{N} / \mathrm{S}$ \\
\hline & & & & Private & & & Fin. & Positvie** \\
\hline & & & \multirow{5}{*}{ ROA } & State & & Min. & & $\mathrm{N} / \mathrm{S}$ \\
\hline & & & & State & & Maj. & & Negative* \\
\hline & & & & Private & & Min. & Legal & Positive** \\
\hline & & & & Private & & Maj. & Legal & $\mathrm{N} / \mathrm{S}$ \\
\hline & & & & Private & & & HongKong & Positive** \\
\hline & & & \multirow{5}{*}{ ROE } & State & & Min. & & $\mathrm{N} / \mathrm{S}$ \\
\hline & & & & State & & Maj. & & Negative** \\
\hline & & & & Private & & Min. & Legal & Positive** \\
\hline & & & & Private & & Maj. & Legal & $\mathrm{N} / \mathrm{S}$ \\
\hline & & & & Private & & & HongKong & $\mathrm{N} / \mathrm{S}$ \\
\hline & & & \multirow{5}{*}{$\begin{array}{l}\text { Market/Book } \\
\text { value }\end{array}$} & State & & Min. & & $\mathrm{N} / \mathrm{S}$ \\
\hline & & & & State & & Maj. & & Negative** \\
\hline & & & & Private & & Min. & Legal & Positive** \\
\hline & & & & Private & & Maj. & Legal & $\mathrm{N} / \mathrm{S}$ \\
\hline & & & & Private & & & HongKong & Positive** \\
\hline \multirow{3}{*}{2} & \multirow{3}{*}{ Qi, Wu and Zhang (2000) } & \multirow{3}{*}{$1991-1996 ; \mathrm{N}=774$} & \multirow{3}{*}{$\Delta \mathrm{ROE}$} & State & & & & Negative** \\
\hline & & & & Mixed & & & Tradable Shares & $\mathrm{N} / \mathrm{S}$ \\
\hline & & & & Private & For. & & Tradable Shares & $\mathrm{N} / \mathrm{S}$ \\
\hline \multirow{3}{*}{2} & \multirow{3}{*}{ Song and Yao (2004) } & \multirow{3}{*}{$\begin{array}{c}11 \text { cities: } \\
\text { 1995-2001; } N=3290\end{array}$} & \multirow{3}{*}{$\begin{array}{c}\text { Pretax } \\
\text { profit/Assets }\end{array}$} & Private & & & & $\mathrm{N} / \mathrm{S}$ \\
\hline & & & & State & & Maj. & & Positive*** \\
\hline & & & & Private & & Maj. & & Positive*** \\
\hline \multirow{8}{*}{2} & \multirow{8}{*}{ Sun, Tong (2003) } & \multirow{8}{*}{$1994-1998 ; N=634$} & \multirow{3}{*}{ EBIT/Sales } & State & & & Listed & $\mathrm{N} / \mathrm{S}$ \\
\hline & & & & Private & Dom. & & Listed & $\mathrm{N} / \mathrm{S}$ \\
\hline & & & & Private & For. & & Listed & $\mathrm{N} / \mathrm{S}$ \\
\hline & & & \multirow{3}{*}{ Return on Sales } & State & & & Listed & $\mathrm{N} / \mathrm{S}$ \\
\hline & & & & Private & Dom. & & Listed & Positive** \\
\hline & & & & Private & For. & & Listed & $\mathrm{N} / \mathrm{S}$ \\
\hline & & & \multirow{2}{*}{$\begin{array}{c}\text { Market/Book } \\
\text { value }\end{array}$} & State & & Maj. & Listed & Negative** \\
\hline & & & & State & & Min. & Listed & Positive** \\
\hline
\end{tabular}


TABLE 4: EFFECT OF OWNERSHIP ON PROFITABILITY

\begin{tabular}{|c|c|c|c|c|c|c|c|c|}
\hline Category & Author(s) & $\begin{array}{c}\text { Country / region, period, } \\
\text { observations }\end{array}$ & $\begin{array}{l}\text { Dependent } \\
\text { variable }\end{array}$ & \multicolumn{4}{|c|}{ Ownership } & \multirow{2}{*}{$\frac{\text { Effect }}{\text { Positive* }^{*}}$} \\
\hline \multirow{2}{*}{2} & \multirow{2}{*}{ Tian and Estrin (2005) } & \multirow{2}{*}{$1994-1998 ; N=2660$} & \multirow{2}{*}{ ROA } & State & & & & \\
\hline & & & & State & & SLO & & Positive*** \\
\hline \multirow{3}{*}{3} & \multirow{3}{*}{ Chen, Firth and Rui (2006) } & \multirow{3}{*}{$1991-2000 ; 1078$} & \multirow{3}{*}{ Return on sales } & State & & & Cent. & Positive** \\
\hline & & & & State & & & Local & $\mathrm{N} / \mathrm{S}$ \\
\hline & & & & Private & & & & Positive*** \\
\hline \multirow{5}{*}{3} & \multirow{5}{*}{ Li and Rozelle (2003) } & \multirow{5}{*}{$\begin{array}{l}\text { Jiangsu, Zhejiang; } \\
\text { 1993-1999; N = 591 }\end{array}$} & \multirow{5}{*}{ Profit rate } & Private & & & & Positive** \\
\hline & & & & Private & & & $\begin{array}{c}\text { Pre- } \\
\text { privatization }\end{array}$ & $\mathrm{N} / \mathrm{S}$ \\
\hline & & & & Private & & & Premium paying & Positive** \\
\hline & & & & Private & & & Mod. Disct. & $\mathrm{N} / \mathrm{S}$ \\
\hline & & & & Private & & & Heav. Disct. & $\mathrm{N} / \mathrm{S}$ \\
\hline \multirow{2}{*}{3} & \multirow{2}{*}{$\mathrm{Li}$ and $\mathrm{Wu}(2002)$} & \multirow{2}{*}{$\begin{array}{c}\text { Jilin, Jiangsu, Shanxi, Sichuan; } \\
\text { 1980-1994; N = } 4414\end{array}$} & \multirow{2}{*}{$\begin{array}{c}\text { Deflated return } \\
\text { on total assets }\end{array}$} & Mngmnt. & & & & Positive $^{* * *}$ \\
\hline & & & & Private & & & & Negative $* * *$ \\
\hline \multirow{3}{*}{3} & \multirow{3}{*}{ Wang (2005) } & \multirow{3}{*}{$1994-1999 ; \mathrm{N}=630$} & \multirow{3}{*}{$\Delta \mathrm{ROA}$} & State & & & & $\mathrm{N} / \mathrm{S}$ \\
\hline & & & & Mixed & & & Legal entity & Positive** \\
\hline & & & & Private & & & Individual & $\mathrm{N} / \mathrm{S}$ \\
\hline \multirow{4}{*}{3} & \multirow{4}{*}{$\begin{array}{c}\text { Wei, Varela, D'Souza and } \\
\text { Hassan (2003) }\end{array}$} & \multirow{4}{*}{$1990-1997 ; \mathrm{N}=1664$} & \multirow{2}{*}{$\begin{array}{c}\% \Delta \text { return on } \\
\text { sales }\end{array}$} & State & & & & $\mathrm{N} / \mathrm{S}$ \\
\hline & & & & Private & For. & & & Positive* \\
\hline & & & \multirow{2}{*}{$\Delta$ real sales } & State & & & & Negative* \\
\hline & & & & Private & For. & & & $\mathrm{N} / \mathrm{S}$ \\
\hline \multirow{8}{*}{3} & \multirow{8}{*}{$\begin{array}{l}\text { Wei, Varela and Hassan } \\
\text { (2002) }\end{array}$} & \multirow{8}{*}{$1994 ; \mathrm{N}=1029-1031$} & \multirow{4}{*}{ Return on Sales } & Coop. & & & & Positive*** \\
\hline & & & & Private & & & Joint Venture & Positive*** \\
\hline & & & & Private & & & Mixed & Positive*** \\
\hline & & & & Private & For. & & & $\mathrm{N} / \mathrm{S}$ \\
\hline & & & & Coop. & & & & Positive*** \\
\hline & & & Return on total & Private & & & Joint Venture & $\mathrm{N} / \mathrm{S}$ \\
\hline & & & assets & Private & & & Mixed & $\mathrm{N} / \mathrm{S}$ \\
\hline & & & & Private & For. & & & $\mathrm{N} / \mathrm{S}$ \\
\hline
\end{tabular}


TABLE 4: EFFECT OF OWNERSHIP ON PROFITABILITY

\begin{tabular}{|c|c|c|c|c|c|c|}
\hline Category & Author(s) & $\begin{array}{c}\text { Country / region, period, } \\
\text { observations }\end{array}$ & $\begin{array}{l}\text { Dependent } \\
\text { variable }\end{array}$ & \multicolumn{2}{|c|}{ Ownership } & Effect \\
\hline \multirow{6}{*}{3} & \multirow{6}{*}{$\mathrm{Xu}$ and Wang (1999) } & \multirow{6}{*}{$1993-1995 ; \mathrm{N}=668$} & \multirow{3}{*}{ ROE } & State & & Negative*** \\
\hline & & & & Mixed & Legal entity & Positive $* * *$ \\
\hline & & & & Private & Individual & $\mathrm{N} / \mathrm{S}$ \\
\hline & & & \multirow{3}{*}{ ROA } & State & & Negative*** \\
\hline & & & & Mixed & Legal entity & Positive*** \\
\hline & & & & Private & Individual & $\mathrm{N} / \mathrm{S}$ \\
\hline
\end{tabular}

$* * *=$ statistical significance at $1 \%$ level; $* *=$ statistical significance at $5 \%$ level; $*=$ statistical significance at $10 \%$ level;

$\mathrm{N} / \mathrm{S}=$ insignificant effect; Positive/Negative $=$ positive/negative effect

Private $=$ Private ownership; State $=$ State ownership; Worker $=$ Worker ownership $;$ Mngmnt. = Manager ownership; Dom. $=$ Domestic ownership; For. $=$ Foreign ownership; Maj. = Majority control; Min. = Minority control; Sm. Min. = Small minority control; Blk. Min. $=$ Blocking minority control

Fin. $=$ Financial; Industrial $=$ Ownership by Industrial firm; Mixed $=$ Mixed ownership; Outsider $=$ Outsider ownership; Insider $=$ Insider Ownership;

List. $=$ Listed; Non-List. $=$ Non-Listed; Small $=$ Small firms; Med. \& Lrg. = Medium \& Large firms; Natl. = National control; De Novo = New firms

Yr. Private $=$ Year privatized; Sub. Yrs. = Subsequent years; Shares $=$ Shareholding; Local = Local government control; Municip. $=$ Municipal control;

Cent. $=$ Central government control; Urban = Urban firms; Rural $=$ Rural firms; Joint $=$ joint venture or joint stock companies;

Coop. $=$ Cooperative; Pre $=$ Preprivatization; Post $=$ Postprivatization; Prem. $=$ Premium paying;

Mod. Disct. $=$ Moderately discounted; Heav. Disct. $=$ Heavily discounted; Legal $=$ Legal persons 
TABLE 5: EFFECT OF OWNERSHIP ON SALES OR REVENUES

\begin{tabular}{|c|c|c|c|c|c|c|c|c|}
\hline Category & Author(s) & $\begin{array}{c}\text { Country / region, period, } \\
\text { observations }\end{array}$ & $\begin{array}{c}\text { Dependent } \\
\text { variable }\end{array}$ & \multicolumn{4}{|c|}{ Ownership } & Effect \\
\hline \multicolumn{9}{|c|}{ PANEL A } \\
\hline \multirow{6}{*}{1} & \multirow{6}{*}{ Andreyeva (2003) } & \multirow{6}{*}{$\begin{array}{c}\text { Ukraine; } \\
1996-2000 ; \mathrm{N}=3497 \text { or } 3909\end{array}$} & \multirow{6}{*}{$\log$ (Sales) } & Private & & & All & Positive** \\
\hline & & & & State & & & Monopoly & Positive** \\
\hline & & & & & & Maj. & & Positive*** \\
\hline & & & & Private & & & Small & $\mathrm{N} / \mathrm{S}$ \\
\hline & & & & & & & Large Outsider & Positive* \\
\hline & & & & & & & Large Insider & $\mathrm{N} / \mathrm{S}$ \\
\hline \multirow{3}{*}{1} & \multirow{3}{*}{$\begin{array}{l}\text { Claessens and Djankov } \\
\qquad(2002)\end{array}$} & \multirow{3}{*}{$\begin{array}{l}7 \text { East European countries; } \\
\text { 1992-1995; } N=6354\end{array}$} & \multirow{3}{*}{ Sales } & Private & & & In 1994 & Negative* \\
\hline & & & & Private & & & In 1993 & $\mathrm{~N} / \mathrm{S}$ \\
\hline & & & & Private & & & Pre-1992 & Positive*** \\
\hline 1 & Grigorian (2000) & $\begin{array}{c}\text { Lithuania; } \\
1995-1997 ; \mathrm{N}=618\end{array}$ & $\log$ (Sales) & Private & & & & Positive*** \\
\hline \multirow{7}{*}{1} & \multirow{7}{*}{$\begin{array}{l}\text { Hanousek, Kocenda, and } \\
\text { Svejnar (2007) }\end{array}$} & \multirow{7}{*}{$\begin{array}{c}\text { Czech Republic; } \\
\text { 1996-1999; N = } 2592\end{array}$} & \multirow{7}{*}{$\% \Delta$ in Sales } & Private & Dom. & & Industrial & $\mathrm{N} / \mathrm{S}$ \\
\hline & & & & Private & Dom. & & \begin{tabular}{|c|} 
Subsequent \\
Ownership - \\
Fin. (non-bank)
\end{tabular} & Negative* \\
\hline & & & & Private & Dom. & & Individual & $\mathrm{N} / \mathrm{S}$ \\
\hline & & & & Private & For. & & $\begin{array}{c}\text { Initial } \\
\text { Ownership - } \\
\text { Industrial } \\
\end{array}$ & Positive*** \\
\hline & & & & Private & For. & & $\begin{array}{c}\text { Subsequent } \\
\text { Ownership - } \\
\text { Industrial } \\
\end{array}$ & Positive* \\
\hline & & & & Private & For. & & Others & $\mathrm{N} / \mathrm{S}$ \\
\hline & & & & State & & Golden Share & & $\mathrm{N} / \mathrm{S}$ \\
\hline 1 & Jones and Mygind (2002) & $\begin{array}{c}\text { Estonia; } \\
\text { 1993-1997; } \mathrm{N}=2485 \\
\end{array}$ & Sales & Private & & Maj. & & Positive** \\
\hline \multirow{5}{*}{1} & \multirow{5}{*}{ Pivovarsky (2001) } & \multirow{5}{*}{$\begin{array}{c}\text { Ukraine; } \\
1998 ; \mathrm{N}=361\end{array}$} & \multirow{5}{*}{ Sales } & State & & Blk. Min. & & $\mathrm{N} / \mathrm{S}$ \\
\hline & & & & State & & Maj. & & $\mathrm{N} / \mathrm{S}$ \\
\hline & & & & Private & & Maj. & & Positive*** \\
\hline & & & & Private & For. & Maj. & & Positive** \\
\hline & & & & Private & Dom. & Maj. & & Positive* \\
\hline 1 & $\begin{array}{l}\text { Perevalov, Gimadii, and } \\
\text { Dobrodey }(2000)\end{array}$ & $\begin{array}{c}\text { Russia; } \\
\text { 1992-1996; } \mathrm{N}=945\end{array}$ & $\% \Delta$ in Sales & Private & & & & $\mathrm{N} / \mathrm{S}$ \\
\hline
\end{tabular}


TABLE 5: EFFECT OF OWNERSHIP ON SALES OR REVENUES

\begin{tabular}{|c|c|c|c|c|c|c|c|}
\hline Category & Author(s) & $\begin{array}{c}\text { Country / region, period, } \\
\text { observations }\end{array}$ & Dependent & \multicolumn{3}{|c|}{ Ownership } & Effect \\
\hline 1 & Salis (2006) & $\begin{array}{c}\text { Slovenian manufacturing firms; } \\
1996-1999 ; \mathrm{N}=980 \\
\end{array}$ & Log(Output) & Private & For. & Acquisition & Positive** \\
\hline 2 & $\begin{array}{c}\text { Angelucci, Estrin, Konings, } \\
\text { Zolkiewski (2002) }\end{array}$ & $\begin{array}{c}\text { Poland; } \\
\text { 1994-1998; } \mathrm{N}=17570\end{array}$ & Sales & Private & & $\begin{array}{c}\text { Largest } \\
\text { shareholder } \\
\text { dummy }\end{array}$ & Positive*** \\
\hline \multirow{2}{*}{2} & \multirow{2}{*}{$\begin{array}{c}\text { Carlin, Fries, Schaffer, } \\
\text { Seabright (2001) } \\
\end{array}$} & \multirow{2}{*}{$\begin{array}{c}25 \text { transition countries; } \\
1996-1998 ; \mathrm{N}=2245\end{array}$} & \multirow{2}{*}{ Sales } & State & & Dummy & $\mathrm{N} / \mathrm{S}$ \\
\hline & & & & Private & & De Novo & Positive** \\
\hline 2 & $\begin{array}{c}\text { Djankov and Hoekman } \\
(2000)\end{array}$ & $\begin{array}{c}\text { Czech Republic; } \\
\text { 1992-1997; } \mathrm{N}=513 \\
\end{array}$ & $\% \Delta$ in Sales & Private & Dom. & Joint venture & $\mathrm{N} / \mathrm{S}$ \\
\hline \multirow{10}{*}{2} & \multirow{10}{*}{$\begin{array}{l}\text { Frydman, Gray, Hessel, } \\
\text { and Rapaczynski (1999) }\end{array}$} & \multirow{10}{*}{$\begin{array}{l}\text { Hungary, Poland, Czech } \\
\text { Republic; } \\
\text { 1990-1993; N = } 513\end{array}$} & \multirow{10}{*}{$\begin{array}{c}\% \Delta \text { in } \\
\text { Revenues }\end{array}$} & Private & & $\begin{array}{c}\text { Privatized effect } \\
\text { dummy }\end{array}$ & Positive** \\
\hline & & & & Private & & Outsider & Positive*** \\
\hline & & & & Private & & Insider & $\mathrm{N} / \mathrm{S}$ \\
\hline & & & & Private & For. & Fin. & Positive* \\
\hline & & & & Private & Dom. & Fin. & Positive*** \\
\hline & & & & Private & Dom. & Industrial & $\mathrm{N} / \mathrm{S}$ \\
\hline & & & & Private & Dom. & Individual & $\mathrm{N} / \mathrm{S}$ \\
\hline & & & & State & & & $\mathrm{N} / \mathrm{S}$ \\
\hline & & & & Mngmnt. & & & $\mathrm{N} / \mathrm{S}$ \\
\hline & & & & Worker & & & $\mathrm{N} / \mathrm{S}$ \\
\hline \multirow{9}{*}{2} & \multirow{9}{*}{$\begin{array}{l}\text { Frydman, Hessel, and } \\
\text { Rapaczynski (2000) }\end{array}$} & \multirow{9}{*}{$\begin{array}{c}\text { Hungary, Poland, Czech } \\
\text { Republic; } \\
\text { 1990-1993; } 215\end{array}$} & \multirow{9}{*}{$\begin{array}{c}\% \Delta \text { in } \\
\text { Revenues }\end{array}$} & State & & $\begin{array}{l}\text { Restructuring } \\
\text { dummy }\end{array}$ & $\mathrm{N} / \mathrm{S}$ \\
\hline & & & & \multirow{2}{*}{ Private } & & $\begin{array}{l}\text { Outsider, Yr. } \\
\text { Priv. }\end{array}$ & $\mathrm{N} / \mathrm{S}$ \\
\hline & & & & & & $\begin{array}{l}\text { Outsider, Subs. } \\
\text { Yrs. }\end{array}$ & $\mathrm{N} / \mathrm{S}$ \\
\hline & & & & \multirow{2}{*}{ Private } & & $\begin{array}{l}\text { Outsider, Yr. } \\
\text { Priv. } \\
\end{array}$ & Positive** \\
\hline & & & & & & $\begin{array}{l}\text { Outsider, Subs. } \\
\text { Yrs. }\end{array}$ & Positive*** \\
\hline & & & & \multirow{2}{*}{ Private } & & $\begin{array}{l}\text { Insider, Yr. } \\
\text { Priv. }\end{array}$ & $\mathrm{N} / \mathrm{S}$ \\
\hline & & & & & & $\begin{array}{l}\text { Insider, Subs. } \\
\text { Yrs. }\end{array}$ & $\mathrm{N} / \mathrm{S}$ \\
\hline & & & & \multirow{2}{*}{ Private } & & $\begin{array}{l}\text { Insider, Yr. } \\
\text { Priv. }\end{array}$ & $\mathrm{N} / \mathrm{S}$ \\
\hline & & & & & & $\begin{array}{l}\text { Insider, Subs. } \\
\text { Yrs. } \\
\end{array}$ & $\mathrm{N} / \mathrm{S}$ \\
\hline
\end{tabular}


TABLE 5: EFFECT OF OWNERSHIP ON SALES OR REVENUES

\begin{tabular}{|c|c|c|c|c|c|c|c|c|}
\hline Category & Author(s) & $\begin{array}{c}\text { Country / region, period, } \\
\text { observations }\end{array}$ & $\begin{array}{c}\text { Dependent } \\
\text { variable }\end{array}$ & \multicolumn{4}{|c|}{ Ownership } & Effect \\
\hline \multirow{3}{*}{2} & \multirow{3}{*}{ Maurel (2001) } & \multirow{3}{*}{$\begin{array}{c}\text { Hungary; } \\
\text { 1992-1998; } \mathrm{N}=30719\end{array}$} & \multirow{3}{*}{$\log ($ Sales $)$} & State & & & & Negative*** \\
\hline & & & & Private & Dom. & & & Positive* \\
\hline & & & & Private & For. & & & Positive** \\
\hline 3 & Batjargal (2000) & $\begin{array}{c}\text { Russia; } \\
1995 \text { \& 1999; } 56\end{array}$ & $\begin{array}{c}\% \Delta \text { in } \\
\text { Revenues }\end{array}$ & Private & & & De Novo & $\mathrm{N} / \mathrm{S}$ \\
\hline \multirow[b]{2}{*}{3} & \multirow[b]{2}{*}{ Bhaumik and Estrin (2003) } & \multirow{2}{*}{$\begin{array}{c}\text { Russia; } \\
\text { 1997-1999; } \mathrm{N}=275\end{array}$} & \multirow[b]{2}{*}{$\% \Delta$ in Sales } & Private & & & Insider & $\mathrm{N} / \mathrm{S}$ \\
\hline & & & & Private & & & $\begin{array}{l}\text { State Control } \\
\text { dummy }\end{array}$ & Negative* \\
\hline \multirow{2}{*}{3} & \multirow{2}{*}{ Bhaumik and Estrin (2005) } & \multirow{2}{*}{$\begin{array}{c}\text { Russia; } \\
1997-1999 ; \mathrm{N}=550\end{array}$} & \multirow{2}{*}{$\Delta \log ($ Sales $)$} & Private & & & & $\mathrm{N} / \mathrm{S}$ \\
\hline & & & & State & & & & $\mathrm{N} / \mathrm{S}$ \\
\hline \multirow{2}{*}{3} & \multirow{2}{*}{ Goud (2003) } & \multirow{2}{*}{$\begin{array}{c}25 \mathrm{CEE} \text { and FSU countries; } \\
1999 ; \mathrm{N}=4104\end{array}$} & \multirow{2}{*}{$\Delta$ Sales } & Private & For. & & Small & Negative*** \\
\hline & & & & Private & For. & & Med. \& Lrg. & Positive*** \\
\hline \multirow{3}{*}{3} & \multirow{3}{*}{$\begin{array}{l}\text { Fries, Neven and Seabright } \\
\text { (2002) }\end{array}$} & \multirow{3}{*}{$\begin{array}{c}16 \text { transition countries; } \\
1994-1999 ; N=475\end{array}$} & \multirow{3}{*}{ Revenues } & Private & & & De Novo & Negative** \\
\hline & & & & Private & & & Dummy & $\mathrm{N} / \mathrm{S}$ \\
\hline & & & & Private & For. & & Dummy & $\mathrm{N} / \mathrm{S}$ \\
\hline \multirow{5}{*}{3} & \multirow{5}{*}{ Jones (1998) } & \multirow{5}{*}{$\begin{array}{c}\text { Russia; } \\
\text { 1992-1996; } \mathrm{N}=99\end{array}$} & \multirow{5}{*}{ Revenues } & Private & & \multirow{5}{*}{$\begin{array}{c}\text { Dominant } \\
\text { owner } \\
\text { dummy }\end{array}$} & & $\mathrm{N} / \mathrm{S}$ \\
\hline & & & & Mngmnt. & & & & $\mathrm{N} / \mathrm{S}$ \\
\hline & & & & Worker & & & & $\mathrm{N} / \mathrm{S}$ \\
\hline & & & & Private & & & Fin. & $\mathrm{N} / \mathrm{S}$ \\
\hline & & & & Private & & & Individual & Negative** \\
\hline
\end{tabular}


TABLE 5: EFFECT OF OWNERSHIP ON SALES OR REVENUES

\begin{tabular}{|c|c|c|c|c|c|c|c|c|}
\hline Category & Author(s) & $\begin{array}{c}\text { Country / region, period, } \\
\text { observations }\end{array}$ & $\begin{array}{l}\text { Dependent } \\
\text { variable }\end{array}$ & \multicolumn{4}{|c|}{ Ownership } & Effect \\
\hline \multicolumn{9}{|c|}{ PANEL B } \\
\hline \multirow{4}{*}{2} & \multirow{4}{*}{$\begin{array}{l}\text { Dong, Putterman and Unel } \\
\text { (2006) }\end{array}$} & \multirow{4}{*}{$\begin{array}{l}\text { Nanjing metropolitan area- } \\
\text { rural (owned by township } \\
\text { governments) and urban } \\
\text { enterprises (owned by central, } \\
\text { provincial and municipal } \\
\text { governments); } \\
\text { 1994-2001; } \mathrm{N}=165\end{array}$} & \multirow{4}{*}{$\begin{array}{l}\text { growth of } \\
\text { revenues per } \\
\text { worker }\end{array}$} & State & & & Urban & Positive*** \\
\hline & & & & Private & & & Urban & $\mathrm{N} / \mathrm{S}$ \\
\hline & & & & State & & & Rural & Positive** \\
\hline & & & & Private & & & Rural & $\mathrm{N} / \mathrm{S}$ \\
\hline 2 & Jia, Sun, Tong (2005) & $1993-2002 ; \mathrm{N}=530$ & $\Delta$ in real sales & State & & Min. & & $\mathrm{N} / \mathrm{S}$ \\
\hline \multirow{3}{*}{2} & \multirow{3}{*}{ Sun, Tong (2003) } & \multirow{3}{*}{$1994-1998 ; \mathrm{N}=634$} & \multirow{3}{*}{$\Delta$ in real sales } & State & & Maj. & & Negative* \\
\hline & & & & Private & For. & Maj. & & $\mathrm{N} / \mathrm{S}$ \\
\hline & & & & & & & Listed & Positive** \\
\hline \multirow{2}{*}{3} & \multirow{2}{*}{ Bhaumik and Estrin (2005) } & \multirow{2}{*}{$\begin{array}{c}\text { China; } \\
\text { 1995-1999; } \mathrm{N}=548-552\end{array}$} & \multirow{2}{*}{$\Delta \log ($ Sales $)$} & State & & & & $\mathrm{N} / \mathrm{S}$ \\
\hline & & & & & & & & $\mathrm{N} / \mathrm{S}$ \\
\hline
\end{tabular}

$* * *=$ statistical significance at $1 \%$ level; $* *=$ statistical significance at $5 \%$ level; $*$ = statistical significance at $10 \%$ level;

$\mathrm{N} / \mathrm{S}=$ insignificant effect; Positive/Negative $=$ positive/negative effect

Private $=$ Private ownership; State $=$ State ownership; Worker $=$ Worker ownership; Mngmnt. = Manager ownership

Dom. $=$ Domestic ownershp; For. $=$ Foreign ownership; Maj. = Majority control; Min. = Minority control

Fin. $=$ Financial; Industrial $=$ Ownership by Industrial firm; Mixed $=$ Mixed ownership; Outsider $=$ Outsider ownership; Insider $=$ Insider Ownership;

List. $=$ Listed; Non-List. $=$ Non-Listed; Small = Small firms; Med. \& Lrg. = Medium \& Large firms; De Novo = New firms

Yr. Private $=$ Year privatized; Sub. Yrs. $=$ Subsequent years; Shares $=$ Shareholding; Local $=$ Local government control

Cent. $=$ Central government control; Urban $=$ Urban firms; Rural $=$ Rural firms; Joint $=$ joint venture or joint stock companies;

Coop. $=$ Cooperative; Pre $=$ Preprivatization; Post $=$ Postprivatization; Collect. $=$ Collective; Prem. $=$ Premium paying;

Mod. Disct. $=$ Moderately discounted; Heav. Disct. $=$ Heavily discounted; Legal $=$ Legal persons 
TABLE 6: EFFECT OF OWNERSHIP ON EMPLOYMENT

\begin{tabular}{|c|c|c|c|c|c|c|c|c|}
\hline Category & Author(s) & $\begin{array}{c}\text { Country / region, period, } \\
\text { observations }\end{array}$ & $\begin{array}{l}\text { Dependent } \\
\text { variable }\end{array}$ & \multicolumn{4}{|c|}{ Ownership } & Effect \\
\hline \multicolumn{9}{|c|}{ PANEL A } \\
\hline \multirow{10}{*}{1} & \multirow{10}{*}{$\begin{array}{l}\text { Basu, Estrin and Svejnar } \\
\text { (1997) }\end{array}$} & \multirow{7}{*}{$\begin{array}{c}\text { Czechoslovakia; } \\
\text { 1989-1993; N = } 2933\end{array}$} & \multirow{7}{*}{$\log (\mathrm{L})$} & Private & & & & $\mathrm{N} / \mathrm{S}$ \\
\hline & & & & Coop. & & & & $\mathrm{N} / \mathrm{S}$ \\
\hline & & & & State & & & & Negative** \\
\hline & & & & State & & & $\begin{array}{c}\text { Local } \\
\text { Government }\end{array}$ & $\mathrm{N} / \mathrm{S}$ \\
\hline & & & & & & & $\begin{array}{c}\text { Civic } \\
\text { Organization } \\
\end{array}$ & Negative*** \\
\hline & & & & Private & For. & & & $\mathrm{N} / \mathrm{S}$ \\
\hline & & & & & & & Joint Venture & Negative** \\
\hline & & \multirow{3}{*}{$\begin{array}{c}\text { Poland; } \\
\text { 1988-1991; } N=261\end{array}$} & \multirow{3}{*}{$\log (\mathrm{L})$} & Private & & & $\begin{array}{c}\text { Emerging } \\
\text { Private Firm }\end{array}$ & $\mathrm{N} / \mathrm{S}$ \\
\hline & & & & Private & & & & Negative*** \\
\hline & & & & State & & & $\begin{array}{c}\text { Commercialized } \\
\text { SOE }\end{array}$ & $\mathrm{N} / \mathrm{S}$ \\
\hline \multirow{3}{*}{1} & \multirow{3}{*}{$\begin{array}{l}\text { Claessens and Djankov } \\
\text { (2002) }\end{array}$} & \multirow{3}{*}{$\begin{array}{l}7 \text { East European countries; } \\
1992-1995 ; \mathrm{N}=6354\end{array}$} & \multirow{3}{*}{ Emloyment } & Private & & Blk. Min. & \begin{tabular}{|l|} 
In 1994 \\
\end{tabular} & $\mathrm{~N} / \mathrm{S}$ \\
\hline & & & & Private & & Blk. Min. & In 1993 & $\mathrm{~N} / \mathrm{S}$ \\
\hline & & & & Private & & Blk. Min. & Pre-1992 & $\mathrm{N} / \mathrm{S}$ \\
\hline \multirow{3}{*}{1} & \multirow{3}{*}{$\begin{array}{l}\text { Konings and Lehmann } \\
\qquad(2002)\end{array}$} & \multirow{3}{*}{ Russia; 1996-1997; N=3 500} & \multirow{3}{*}{ Labor demand } & State & & & Mixed & Positive** \\
\hline & & & & $\begin{array}{l}\text { State \& } \\
\text { Private }\end{array}$ & & & & $\mathrm{N} / \mathrm{S}$ \\
\hline & & & & Private & & & Mixed & $\mathrm{N} / \mathrm{S}$ \\
\hline 1 & Konings and Walsh (1999) & $\begin{array}{c}\text { Ukraine; } \\
1997 ; \mathrm{N}=215\end{array}$ & $\% \Delta$ in Labor & Private & & & $\begin{array}{l}\text { De Novo } \\
\text { Dummy }\end{array}$ & Positive** \\
\hline \multirow{2}{*}{1} & \multirow{2}{*}{ Konings and Xavier (2003) } & Slovenia; & \multirow{2}{*}{$\% \Delta$ in Labor } & Private & Dom. & & & Positive** \\
\hline & & $1994-1998 ; \mathrm{N}=2656$ & & Private & For. & Maj. & & Positive** \\
\hline 1 & $\begin{array}{l}\text { Perevalov, Gimadi, and } \\
\text { Dobrodey (2000) }\end{array}$ & $\begin{array}{c}\text { Russia; } \\
\text { 1992-1996; } \mathrm{N}=945 \\
\end{array}$ & $\mathrm{~L}$ & Private & & & & $\mathrm{N} / \mathrm{S}$ \\
\hline 1 & Salis (2006) & $\begin{array}{c}\text { Slovenian manufacturing firms; } \\
1996-1999 ; \mathrm{N}=980 \\
\end{array}$ & $\begin{array}{c}\log \\
\text { (Employment) }\end{array}$ & Private & For. & & Acquisition & $\mathrm{N} / \mathrm{S}$ \\
\hline
\end{tabular}


TABLE 6: EFFECT OF OWNERSHIP ON EMPLOYMENT

\begin{tabular}{|c|c|c|c|c|c|c|c|}
\hline Category & Author(s) & $\begin{array}{c}\text { Country / region, period, } \\
\text { observations }\end{array}$ & $\begin{array}{l}\text { Dependent } \\
\text { variable }\end{array}$ & \multicolumn{3}{|c|}{ Ownership } & Effect \\
\hline \multirow{14}{*}{2} & \multirow{14}{*}{ Brown, Earle (2002) } & \multirow{14}{*}{$\begin{array}{c}\text { Russia; } \\
1985-1999 ; \mathrm{N}=15 \text { 429-20 } 434\end{array}$} & \multirow{7}{*}{$\begin{array}{l}\text { Growth of } \\
\text { Employment }\end{array}$} & Private & & & Positive** \\
\hline & & & & Non-State & & $\begin{array}{c}\text { Municipal } \\
\text { dummy }\end{array}$ & $\mathrm{N} / \mathrm{S}$ \\
\hline & & & & Non-State & & $\begin{array}{c}\text { Regional } \\
\text { dummy }\end{array}$ & $\mathrm{N} / \mathrm{S}$ \\
\hline & & & & Non-State & & $\begin{array}{c}\text { Public } \\
\text { Organization } \\
\text { dummy } \\
\end{array}$ & $\mathrm{N} / \mathrm{S}$ \\
\hline & & & & Private & & Mixed & $\mathrm{N} / \mathrm{S}$ \\
\hline & & & & Private & & & Positive** \\
\hline & & & & Private & For. & & Positive** \\
\hline & & & \multirow{7}{*}{ Job realocation } & Private & & & $\mathrm{N} / \mathrm{S}$ \\
\hline & & & & Non-State & & $\begin{array}{c}\text { Municipal } \\
\text { dummy }\end{array}$ & Positive** \\
\hline & & & & Non-State & & $\begin{array}{c}\text { Regional } \\
\text { dummy }\end{array}$ & $\mathrm{N} / \mathrm{S}$ \\
\hline & & & & Non-State & & $\begin{array}{c}\text { Public } \\
\text { Organization } \\
\text { dummy } \\
\end{array}$ & Negative** \\
\hline & & & & Private & & Mixed & $\mathrm{N} / \mathrm{S}$ \\
\hline & & & & Private & & & Positive** \\
\hline & & & & Private & For. & & Positive** \\
\hline \multirow{4}{*}{2} & \multirow{4}{*}{$\begin{array}{c}\text { Domadenik, Prasnikar and } \\
\text { Svejnar (2003) }\end{array}$} & \multirow{4}{*}{$\begin{array}{c}\text { Slovenia; } \\
\text { 1996-1998; } N=200\end{array}$} & \multirow{4}{*}{$\begin{array}{l}\log (\text { Labor } \\
\text { adjustment) }\end{array}$} & Private & & Priv.dummy & $\mathrm{N} / \mathrm{S}$ \\
\hline & & & & Labor & & & $\mathrm{N} / \mathrm{S}$ \\
\hline & & & & State & & Fin. & $\mathrm{N} / \mathrm{S}$ \\
\hline & & & & Private & & Industrial & $\mathrm{N} / \mathrm{S}$ \\
\hline \multirow{10}{*}{2} & \multirow{10}{*}{$\begin{array}{l}\text { Frydman, Gray, Hessel, } \\
\text { and Rapaczynski (1999) }\end{array}$} & \multirow{10}{*}{$\begin{array}{c}\text { Hungary, Poland, Czech } \\
\text { Republic; } \\
\text { 1990-1993; N = } 493\end{array}$} & \multirow{10}{*}{$\% \Delta$ in Labor } & Private & & & Positive* \\
\hline & & & & Private & & Outsider & $\mathrm{N} / \mathrm{S}$ \\
\hline & & & & Private & & Insider & $\mathrm{N} / \mathrm{S}$ \\
\hline & & & & Private & For. & Fin. & Positive** \\
\hline & & & & Private & Dom. & Fin. & $\mathrm{N} / \mathrm{S}$ \\
\hline & & & & Private & Dom. & Industrial & $\mathrm{N} / \mathrm{S}$ \\
\hline & & & & Private & Dom. & Individual & $\mathrm{N} / \mathrm{S}$ \\
\hline & & & & State & & & $\mathrm{N} / \mathrm{S}$ \\
\hline & & & & Mngmnt. & & & Positive* \\
\hline & & & & Worker & & & $\mathrm{N} / \mathrm{S}$ \\
\hline
\end{tabular}


TABLE 6: EFFECT OF OWNERSHIP ON EMPLOYMENT

\begin{tabular}{|c|c|c|c|c|c|c|c|c|}
\hline Category & Author(s) & $\begin{array}{c}\text { Country / region, period, } \\
\text { observations }\end{array}$ & $\begin{array}{l}\text { Dependent } \\
\text { variable }\end{array}$ & \multicolumn{4}{|c|}{ Ownership } & Effect \\
\hline \multirow{6}{*}{2} & \multirow{6}{*}{ Faggio and Konings (2003) } & \multirow{2}{*}{ Poland; 1993-1997; N = 738} & \multirow{2}{*}{$\% \Delta$ in Labor } & State & & & & Negative ${ }^{* * *}$ \\
\hline & & & & Private & For. & & & Positive* \\
\hline & & \multirow{2}{*}{$\begin{array}{c}\text { Bulgaria; } 1993-1997 ; \mathrm{N}=4 \\
679\end{array}$} & \multirow{2}{*}{$\% \Delta$ in Labor } & State & & & & Negative** $^{* *}$ \\
\hline & & & & Private & For. & & & $\mathrm{N} / \mathrm{S}$ \\
\hline & & \multirow{2}{*}{ Romania; 1993-1997; 5203} & \multirow{2}{*}{$\% \Delta$ in Labor } & State & & & & Negative*** \\
\hline & & & & Private & For. & & & Positive*** \\
\hline \multirow{4}{*}{2} & \multirow{4}{*}{ Mickiewicz (2005) } & \multirow{4}{*}{ Poland; 1996-2002; N=1 911} & \multirow{4}{*}{$\Delta$ Employment } & Private & For. & & De Novo & Positive** \\
\hline & & & & Private & Dom. & & De Novo & $\mathrm{N} / \mathrm{S}$ \\
\hline & & & & Privatized & & & 3-6yrs later & Positive*** \\
\hline & & & & Privatized & & & 7yrs and more & $\mathrm{N} / \mathrm{S}$ \\
\hline 2 & Walsh and Whelan (2001) & $\begin{array}{l}\text { Bulgaria, Hungary, Slovakia, } \\
\text { Slovenia; } \\
\text { 1990-1996; N =938-1 } 003 \\
\end{array}$ & $\% \Delta$ in Labor & Private & & Maj. & De Novo & Positive** \\
\hline \multirow{3}{*}{3} & \multirow{3}{*}{$\begin{array}{l}\text { Bakanova, Estrin, Pelipas } \\
\text { and Pukovic (2006) }\end{array}$} & \multirow{3}{*}{$\begin{array}{c}\text { Belarus; } \\
2004 ; \mathrm{N}=402\end{array}$} & \multirow{3}{*}{$\begin{array}{l}\text { employment } \\
\text { growth }\end{array}$} & Private & & & De Novo & $\mathrm{N} / \mathrm{S}$ \\
\hline & & & & Private & & Min. & & $\mathrm{N} / \mathrm{S}$ \\
\hline & & & & Private & & Maj. & & $\begin{array}{l}\text { Positive**; } \\
\text { Positive** }\end{array}$ \\
\hline \multirow{6}{*}{3} & \multirow{6}{*}{ Bilsen and Konings (1998) } & \multirow{2}{*}{$\begin{array}{c}\text { Bulgaria; } \\
\text { 1991-1994; } \mathrm{N}=95\end{array}$} & \multirow{2}{*}{$\% \Delta$ in Labor } & Private & & & Privatiz. dummy & $\mathrm{N} / \mathrm{S}$ \\
\hline & & & & Private & & & De Novo & Positive** \\
\hline & & \multirow{2}{*}{$\begin{array}{c}\text { Hungary; } \\
\text { 1991-1994; } N=76\end{array}$} & \multirow{2}{*}{$\% \Delta$ in Labor } & Private & & & Privatiz. dummy & $\mathrm{N} / \mathrm{S}$ \\
\hline & & & & Private & & & De Novo & $\mathrm{N} / \mathrm{S}$ \\
\hline & & \multirow{2}{*}{$\begin{array}{c}\text { Romania; } \\
\text { 1991-1994; } \mathrm{N}=85\end{array}$} & \multirow[t]{2}{*}{$\% \Delta$ in Labor } & Private & & & Privatiz. dummy & $\mathrm{N} / \mathrm{S}$ \\
\hline & & & & Private & & & De Novo & Positive** \\
\hline \multirow{2}{*}{3} & \multirow{2}{*}{ Goud (2003) } & \multirow{2}{*}{$\begin{array}{c}25 \mathrm{CEE} \text { and FSU countries; } \\
1999 ; \mathrm{N}=4104\end{array}$} & \multirow{2}{*}{$\Delta$ in Labor } & Private & & & Small & Positive*** \\
\hline & & & & Private & & & Med. \& Lrg. & Positive** \\
\hline & & & & Private & & & Priv.dummy & $\mathrm{N} / \mathrm{S}$ \\
\hline & & & & Mngmnt. & & & & $\mathrm{N} / \mathrm{S}$ \\
\hline 3 & Jones (1998) & Russia; & I & Worker & & & & $\mathrm{N} / \mathrm{S}$ \\
\hline 3 & Jones (1998) & $1992-1996 ; \mathrm{N}=97$ & $\mathrm{~L}$ & Private & & & Fin. & $\mathrm{N} / \mathrm{S}$ \\
\hline & & & & Private & & & $\begin{array}{l}\text { Outsider; } \\
\text { Individual }\end{array}$ & $\mathrm{N} / \mathrm{S}$ \\
\hline & & & & Private & Dom. & & & Positive*** \\
\hline 3 & Konings, Lenmann and & $\begin{array}{c}\text { Poland; } \\
1988-1991 \cdot \mathrm{N}=7405\end{array}$ & $\% \Delta$ in Labor & Private & For. & & & Positive*** \\
\hline & & & & Private & & Maj. & & $\mathrm{N} / \mathrm{S}$ \\
\hline
\end{tabular}


TABLE 6: EFFECT OF OWNERSHIP ON EMPLOYMENT

\begin{tabular}{|c|c|c|c|c|c|c|c|}
\hline Category & Author(s) & $\begin{array}{c}\text { Country / region, period, } \\
\text { observations }\end{array}$ & $\begin{array}{l}\text { Dependent } \\
\text { variable }\end{array}$ & \multicolumn{3}{|c|}{ Ownership } & Effect \\
\hline \multicolumn{8}{|c|}{ PANEL B } \\
\hline \multirow{4}{*}{1} & \multirow{4}{*}{$\begin{array}{l}\text { Lane, Broadman, Singh } \\
\text { (1998) }\end{array}$} & \multirow{2}{*}{$\begin{array}{c}\text { not specified; } \\
1980-1990 ; \mathrm{N}=5935\end{array}$} & \multirow{2}{*}{ Job creation } & State & & Reorganized & Negative* \\
\hline & & & & Collect. & & Reorganized & Negative* \\
\hline & & \multirow{2}{*}{$\begin{array}{c}\text { not specified; } \\
1980-1990 ; \mathrm{N}=3768\end{array}$} & \multirow{2}{*}{ Job destruction } & State & & Reorganized & Negative* \\
\hline & & & & Collect. & & Reorganized & Negative* \\
\hline \multirow{2}{*}{3} & \multirow{2}{*}{$\begin{array}{c}\text { Wei, Varela, D'Souza and } \\
\text { Hassan (2003) }\end{array}$} & \multirow{2}{*}{$1990-1997 ; \mathrm{N}=656$} & \multirow{2}{*}{$\begin{array}{c}\% \Delta \text { in } \\
\text { employment }\end{array}$} & State & & & Negative*** $^{* *}$ \\
\hline & & & & Private & For. & & $\mathrm{N} / \mathrm{S}$ \\
\hline
\end{tabular}

$* * *=$ statistical significance at $1 \%$ level; $* *=$ statistical significance at $5 \%$ level; $*$ = statistical significance at $10 \%$ level;

$\mathrm{N} / \mathrm{S}=$ insignificant effect; Positive/Negative $=$ positive/negative effect

Private $=$ Private ownership; State $=$ State ownership; Worker $=$ Worker ownership $;$ Mngmnt. $=$ Manager ownership

Dom. $=$ Domestic ownershp; For. $=$ Foreign ownership; Maj. = Majority control; Min. $=$ Minority control

Fin. = Financial; Industrial=Ownership by Industrial firm; Mixed = Mixed ownership; Outsider = Outsider ownership; Insider = Insider Ownership;

List. $=$ Listed; Non-List. $=$ Non-Listed; Small = Small firms; Med. \& Lrg. = Medium \& Large firms; De Novo = New firms

Yr. Private $=$ Year privatized; Sub. Yrs. $=$ Subsequent years; Shares $=$ Shareholding; Local = Local government control

Cent. $=$ Central government control; Urban $=$ Urban firms; Rural $=$ Rural firms; Joint $=$ joint venture or joint stock companies;

Coop. $=$ Cooperative; Pre $=$ Preprivatization; Post $=$ Postprivatization; Prem. $=$ Premium paying;

Mod. Disct. = Moderately discounted; Heav. Disct. $=$ Heavily discounted; Legal $=$ Legal persons 
TABLE 7: EFFECT OF OWNERSHIP ON WAGES

\begin{tabular}{|c|c|c|c|c|c|c|c|}
\hline Category & Author(s) & $\begin{array}{c}\text { Country / region, period, } \\
\text { observations }\end{array}$ & $\begin{array}{l}\text { Dependent } \\
\text { variable }\end{array}$ & \multicolumn{3}{|c|}{ Ownership } & Effect \\
\hline \multicolumn{8}{|c|}{ PANEL A } \\
\hline \multirow{10}{*}{1} & \multirow{10}{*}{$\begin{array}{l}\text { Basu, Estrin and Svejnar } \\
\text { (1997) }\end{array}$} & \multirow{7}{*}{$\begin{array}{c}\text { Czechoslovakia; } \\
\text { 1989-1993; } \mathrm{N}=2933\end{array}$} & \multirow{7}{*}{$\log$ (Wage) } & Private & & Private & $\mathrm{N} / \mathrm{S}$ \\
\hline & & & & Coop. & & & $\mathrm{N} / \mathrm{S}$ \\
\hline & & & & State & & & Negative* \\
\hline & & & & State & & Local & $\mathrm{N} / \mathrm{S}$ \\
\hline & & & & & & $\begin{array}{c}\text { Civic } \\
\text { Organization }\end{array}$ & Positive*** \\
\hline & & & & Private & For. & & $\mathrm{N} / \mathrm{S}$ \\
\hline & & & & & & Joint Venture & $\mathrm{N} / \mathrm{S}$ \\
\hline & & \multirow{3}{*}{$\begin{array}{c}\text { Poland; } \\
\text { 1988-1991; } \mathrm{N}=157\end{array}$} & \multirow{3}{*}{$\log$ (Wage) } & & & $\begin{array}{c}\text { Emerging } \\
\text { Private Firm }\end{array}$ & $\mathrm{N} / \mathrm{S}$ \\
\hline & & & & Private & & Privatized & $\mathrm{N} / \mathrm{S}$ \\
\hline & & & & State & & Maj. & $\mathrm{N} / \mathrm{S}$ \\
\hline \multirow{8}{*}{1} & \multirow{8}{*}{$\begin{array}{l}\text { Earle and Sabirianova } \\
\qquad(2002)\end{array}$} & \multirow{8}{*}{$\begin{array}{c}\text { Russia; } \\
\text { 1994-1996; } \mathrm{N}=6 \text { 731-6 } 898\end{array}$} & \multirow{8}{*}{ Wage arreas } & \multirow{2}{*}{ Private } & & Mixed; Probit & Negative*** \\
\hline & & & & & & Mixed; Tobit & Negative** \\
\hline & & & & \multirow{2}{*}{ Private } & \multirow{2}{*}{ Dom. } & Probit & Negative*** \\
\hline & & & & & & Tobit & $\mathrm{N} / \mathrm{S}$ \\
\hline & & & & \multirow{2}{*}{ Private } & \multirow{2}{*}{ For. } & Probit & Negative** \\
\hline & & & & & & Tobit & $\mathrm{N} / \mathrm{S}$ \\
\hline & & & & \multirow{2}{*}{ Private } & & De Novo; Probit & Negative*** \\
\hline & & & & & & De Novo; Tobit & Negative*** \\
\hline 1 & $\begin{array}{c}\text { Lehmann, Wadsworth, and } \\
\text { Acquisti (1999) } \\
\end{array}$ & $\begin{array}{c}\text { Russia; } \\
\text { 1994-1997; } \mathrm{N}=12657 \\
\end{array}$ & Wage arreas & Private & & & Negative** \\
\hline \multirow{2}{*}{3} & \multirow{2}{*}{ Brainerd (2002) } & \multirow{2}{*}{$\begin{array}{c}\text { Russia; } \\
\text { 1993-1998; } \mathrm{N}=2659\end{array}$} & \multirow{2}{*}{$\log$ (Wage) } & Private & & & Positive*** \\
\hline & & & & State & & Mixed & Positive*** \\
\hline \multirow{3}{*}{3} & \multirow{3}{*}{ Grosfeld and Nivet (1999) } & \multirow{3}{*}{$\begin{array}{c}\text { Poland; } \\
\text { 1988-1994; } \mathrm{N}=412,211 \text { or } 55\end{array}$} & \multirow{3}{*}{$\% \Delta$ in Wages } & State & & & Positive** \\
\hline & & & & State & & Maj. & Positive** \\
\hline & & & & Private & & & $\mathrm{N} / \mathrm{S}$ \\
\hline
\end{tabular}

$* * *=$ statistical significance at $1 \%$ level; $* *=$ statistical significance at $5 \%$ level; $*$ = statistical significance at $10 \%$ level;

$\mathrm{N} / \mathrm{S}=$ insignificant effect; Positive/Negative $=$ positive/negative effect

Private $=$ Private ownership; State $=$ State ownership; Worker $=$ Worker ownership; Mngmnt. $=$ Manager ownership

Dom. $=$ Domestic ownershp; For. $=$ Foreign ownership; Maj. $=$ Majority control; Min. $=$ Minority control; Local = Local government control

Fin. = Financial; Industrial=Ownership by Industrial firm; Mixed = Mixed ownership; Outsider = Outsider ownership; Insider $=$ Insider Ownership;

List. $=$ Listed; Non-List. $=$ Non-Listed; Small $=$ Small firms; Med. \& Lrg. = Medium \& Large firms; De Novo = New firms; Coop. $=$ Cooperative 
TABLE 8: EFFECT OF OWNERSHIP ON OTHER INDICATORS OF PERFORMANCE

\begin{tabular}{|c|c|c|c|c|c|c|c|c|}
\hline Category & Author(s) & $\begin{array}{c}\text { Country / region, period, } \\
\text { observations }\end{array}$ & $\begin{array}{c}\text { Dependent } \\
\text { variable }\end{array}$ & \multicolumn{4}{|c|}{ Ownership } & Effect \\
\hline \multicolumn{9}{|c|}{ PANEL A } \\
\hline \multirow{2}{*}{1} & \multirow{2}{*}{ Bena and Hanousek (2006) } & \multirow{2}{*}{$\begin{array}{c}\text { Czech Republic; } \\
1996-2003 ; N=5437\end{array}$} & \multirow{2}{*}{$\begin{array}{l}\text { Probability to } \\
\text { pay dividends }\end{array}$} & Private & Dom. & & & Negative*** \\
\hline & & & & Private & For. & & & Positive* \\
\hline \multirow{5}{*}{1} & \multirow{5}{*}{$\begin{array}{c}\text { Claessens, Djankov and } \\
\text { Pohl (1997) }\end{array}$} & \multirow{5}{*}{$\begin{array}{c}\text { Czech Republic; } \\
\text { 1992-1995; N = } 2490\end{array}$} & \multirow{5}{*}{ Tobin Q } & Private & & & BankFund & Positive* \\
\hline & & & & Private & Dom. & & Fin. & $\mathrm{N} / \mathrm{S}$ \\
\hline & & & & Private & & & Non-Bank Fund & $\mathrm{N} / \mathrm{S}$ \\
\hline & & & & State & & & & $\mathrm{N} / \mathrm{S}$ \\
\hline & & & & Private & For. & & Industrial (FDI) & $\mathrm{N} / \mathrm{S}$ \\
\hline 1 & Grigorian (2000) & $\begin{array}{c}\text { Lithuania; } \\
1995-1997 ; \mathrm{N}=612\end{array}$ & $\log$ (exports) & Private & & & & Positive*** \\
\hline \multirow{12}{*}{1} & \multirow{12}{*}{$\begin{array}{c}\text { Hanousek, Kocenda, and } \\
\text { Svejnar (2004) }\end{array}$} & \multirow{12}{*}{$\begin{array}{c}\text { Czech Republic; } \\
\text { 1990-1996; N = } 2592\end{array}$} & \multirow{4}{*}{$\begin{array}{l}\% \Delta \text { Labor } \\
\text { costs/Sales }\end{array}$} & Private & & & Industrial & Negative $* * *$ \\
\hline & & & & Private & & & Fin. & $\mathrm{N} / \mathrm{S}$ \\
\hline & & & & Private & & & Individual & $\mathrm{N} / \mathrm{S}$ \\
\hline & & & & State & & Golden Share & & $\mathrm{N} / \mathrm{S}$ \\
\hline & & & \multirow{4}{*}{$\begin{array}{c}\% \Delta \\
\text { Profit/Labor } \\
\text { costs }\end{array}$} & Private & & & Industrial & Negative*** \\
\hline & & & & Private & & & Fin. & $\mathrm{N} / \mathrm{S}$ \\
\hline & & & & Private & & & Individual & $\mathrm{N} / \mathrm{S}$ \\
\hline & & & & State & & Golden Share & & $\mathrm{N} / \mathrm{S}$ \\
\hline & & & \multirow{4}{*}{$\begin{array}{c}\% \Delta \\
\text { Profit/Equity }\end{array}$} & Private & & & Industrial & Negative*** \\
\hline & & & & Private & & & Fin. & $\mathrm{N} / \mathrm{S}$ \\
\hline & & & & Private & & & Individual & $\mathrm{N} / \mathrm{S}$ \\
\hline & & & & State & & Golden Share & & $\mathrm{N} / \mathrm{S}$ \\
\hline \multirow{12}{*}{1} & \multirow{12}{*}{ Kocenda (2003) } & \multirow{12}{*}{$\begin{array}{c}\text { Czech Republic; } \\
\text { 1996-1999; N = } 2418\end{array}$} & \multirow{4}{*}{ Total assets } & State & & & & $\mathrm{N} / \mathrm{S}$ \\
\hline & & & & Private & & & Industrial & $\mathrm{N} / \mathrm{S}$ \\
\hline & & & & Private & & & Fin. & Negative** $^{* *}$ \\
\hline & & & & Private & & & Individual & $\mathrm{N} / \mathrm{S}$ \\
\hline & & & \multirow{4}{*}{$\begin{array}{c}\text { Long term bank } \\
\text { loans }\end{array}$} & State & & & & Negative* \\
\hline & & & & Private & & & Industrial & Negative*** \\
\hline & & & & Private & & & Fin. & Negative ${ }^{* * *}$ \\
\hline & & & & Private & & & Individual & $\mathrm{N} / \mathrm{S}$ \\
\hline & & & \multirow{4}{*}{$\begin{array}{c}\text { Cash } \\
\text { flow/equity }\end{array}$} & State & & & & $\mathrm{N} / \mathrm{S}$ \\
\hline & & & & Private & & & Industrial & $\mathrm{N} / \mathrm{S}$ \\
\hline & & & & Private & & & Fin. & Negative** \\
\hline & & & & Private & & & Individual & Negative*** \\
\hline
\end{tabular}


TABLE 8: EFFECT OF OWNERSHIP ON OTHER INDICATORS OF PERFORMANCE

\begin{tabular}{|c|c|c|c|c|c|c|c|c|}
\hline Category & Author(s) & $\begin{array}{c}\text { Country / region, period, } \\
\text { observations }\end{array}$ & $\begin{array}{l}\text { Dependent } \\
\text { variable }\end{array}$ & \multicolumn{4}{|c|}{ Ownership } & \multirow{2}{*}{$\frac{\text { Effect }}{\text { Negative* }^{*}}$} \\
\hline 1 & $\begin{array}{l}\text { Perevalov, Gimadii, and } \\
\text { Dobrodey }(2000)\end{array}$ & $\begin{array}{c}\text { Russia; } \\
\text { 1992-1996; } \mathrm{N}=945\end{array}$ & Unit costs & Private & & & & \\
\hline \multirow{5}{*}{1} & \multirow{5}{*}{ Pivovarsky (2001) } & \multirow{5}{*}{$\begin{array}{c}\text { Ukraine; } \\
\text { 1998; } \mathrm{N}=361-374\end{array}$} & \multirow{5}{*}{ Input/ Revenues } & State & & Blk. Min. & & $\mathrm{N} / \mathrm{S}$ \\
\hline & & & & State & & Maj. & & $\mathrm{N} / \mathrm{S}$ \\
\hline & & & & Private & & Maj. & & Negative**** \\
\hline & & & & Private & For. & Maj. & & Negative*** \\
\hline & & & & Private & Dom. & Maj. & & Negative* \\
\hline \multirow{3}{*}{1} & \multirow{3}{*}{ Pivovarsky (2003) } & \multirow{3}{*}{$\begin{array}{c}\text { Ukraine; } \\
1998 ; \mathrm{N}=361\end{array}$} & \multirow{3}{*}{ Input/ Revenues } & State & & Blk. Min. & & $\mathrm{N} / \mathrm{S}$ \\
\hline & & & & State & & Maj. & & $\mathrm{N} / \mathrm{S}$ \\
\hline & & & & Private & & Maj. & & Negative*** \\
\hline \multirow{4}{*}{2} & \multirow{4}{*}{$\begin{array}{l}\text { Akimova and Schwödiauer } \\
\qquad(2000)\end{array}$} & \multirow{4}{*}{$\begin{array}{c}\text { Ukraine; } \\
1993-1997 ; \mathrm{N}=56 \text { or } 174\end{array}$} & \multirow{4}{*}{$\begin{array}{l}\text { Index of } \\
\text { restructuring } \\
\text { activity }\end{array}$} & Private & & & & $\mathrm{N} / \mathrm{S}$ \\
\hline & & & & Private & & & Outsider & $\mathrm{N} / \mathrm{S}$ \\
\hline & & & & Private & & Maj. & Insider & $\mathrm{N} / \mathrm{S}$ \\
\hline & & & & Private & & Maj. & Outsider & $\mathrm{N} / \mathrm{S}$ \\
\hline 2 & $\begin{array}{l}\text { Csermely and Vincze } \\
\text { (1999) }\end{array}$ & $\begin{array}{c}\text { Hungary; } \\
\text { 1994-1996; } \mathrm{N}=3469\end{array}$ & $\begin{array}{c}\text { Bank } \\
\text { credit/Total } \\
\text { liabilities } \\
\end{array}$ & Private & For. & & & $\mathrm{N} / \mathrm{S}$ \\
\hline \multirow{12}{*}{2} & \multirow{12}{*}{ Djankov (1999b) } & \multirow{12}{*}{$\begin{array}{c}\text { Georgia, Moldova, Kazakhstan, } \\
\text { Kyrgyz, Russia, Ukraine; } \\
\text { 1995-1997; N = } 960\end{array}$} & \multirow{6}{*}{ Asset sales } & Mngmnt. & & & & $\mathrm{N} / \mathrm{S}$ \\
\hline & & & & Worker & & & & $\mathrm{N} / \mathrm{S}$ \\
\hline & & & & State & & & & $\mathrm{N} / \mathrm{S}$ \\
\hline & & & & Private & Dom. & & Outsider & $\mathrm{N} / \mathrm{S}$ \\
\hline & & & & Private & For. & & Outsider & Positive** \\
\hline & & & & Private & & & Individual & $\mathrm{N} / \mathrm{S}$ \\
\hline & & & \multirow{6}{*}{ Renovation } & Mngmnt. & & & & $\mathrm{N} / \mathrm{S}$ \\
\hline & & & & Worker & & & & $\mathrm{N} / \mathrm{S}$ \\
\hline & & & & State & & & & $\mathrm{N} / \mathrm{S}$ \\
\hline & & & & Private & Dom. & & Outsider & $\mathrm{N} / \mathrm{S}$ \\
\hline & & & & Private & For. & & Outsider & Positive* \\
\hline & & & & Private & & & Individual & $\mathrm{N} / \mathrm{S}$ \\
\hline
\end{tabular}


TABLE 8: EFFECT OF OWNERSHIP ON OTHER INDICATORS OF PERFORMANCE

\begin{tabular}{|c|c|c|c|c|c|c|c|}
\hline Category & Author(s) & $\begin{array}{c}\text { Country / region, period, } \\
\text { observations }\end{array}$ & $\begin{array}{c}\text { Dependent } \\
\text { variable }\end{array}$ & \multicolumn{3}{|c|}{ Ownership } & Effect \\
\hline \multirow{6}{*}{2} & \multirow{6}{*}{$\begin{array}{c}\text { Domadenik, Prasnikar and } \\
\text { Svejnar (2003) }\end{array}$} & \multirow{6}{*}{$\begin{array}{c}\text { Slovenia; } \\
\text { 1996-1998; } \mathrm{N}=237\end{array}$} & \multirow{6}{*}{$\begin{array}{l}\text { Investment in } \\
\text { fixed assets }\end{array}$} & Private & & Privatiz. dummy & $\mathrm{N} / \mathrm{S}$ \\
\hline & & & & Labor & & & $\mathrm{N} / \mathrm{S}$ \\
\hline & & & & State & & Fin. & $\mathrm{N} / \mathrm{S}$ \\
\hline & & & & Private & & Industrial & Positive* \\
\hline & & & & $\begin{array}{l}\text { Private \& } \\
\text { State }\end{array}$ & & Fin. & $\mathrm{N} / \mathrm{S}$ \\
\hline & & & & Private & & $\begin{array}{c}\text { Non-employees' } \\
\text { representatives } \\
\text { on the } \\
\text { Supervisory } \\
\text { Board }\end{array}$ & $\mathrm{N} / \mathrm{S}$ \\
\hline \multirow{2}{*}{2} & \multirow{2}{*}{ Earnhart and Lízal (2006) } & \multirow{2}{*}{$\begin{array}{c}\text { Czech Republic; } \\
\text { 1993-1998; N=1 } 127\end{array}$} & \multirow{2}{*}{$\begin{array}{c}\text { Absolute } \\
\text { environmental }\end{array}$} & State & & & Negative*** \\
\hline & & & & Private & & & $\mathrm{N} / \mathrm{S}$ \\
\hline \multirow{7}{*}{2} & \multirow{7}{*}{$\begin{array}{l}\text { Everaert and Hildebrandt } \\
\text { (2001) }\end{array}$} & \multirow{4}{*}{$\begin{array}{c}\text { Bulgaria; } \\
\text { 1995-1999; } \mathrm{N}=3777\end{array}$} & \multirow{4}{*}{$\begin{array}{l}\text { Soft budget } \\
\text { constraint }\end{array}$} & State & & & Positive** \\
\hline & & & & Private & For. & & $\mathrm{N} / \mathrm{S}$ \\
\hline & & & & Private & & Insider & $\mathrm{N} / \mathrm{S}$ \\
\hline & & & & State & & Municip. & $\mathrm{N} / \mathrm{S}$ \\
\hline & & \multirow{3}{*}{$\begin{array}{c}\text { Romania; } \\
\text { 1995-1999; } N=6646\end{array}$} & \multirow{3}{*}{$\begin{array}{l}\text { Soft budget } \\
\text { constraint }\end{array}$} & State & & & Positive** \\
\hline & & & & Private & For. & & Positive** \\
\hline & & & & Private & & Insider & Negative** \\
\hline \multirow{3}{*}{2} & \multirow{3}{*}{$\begin{array}{c}\text { Fries, Neven and Seabright } \\
\text { (2002) }\end{array}$} & \multirow{3}{*}{$\begin{array}{l}16 \text { transition countries; } \\
\text { 1994-1999; } N=1725\end{array}$} & \multirow{3}{*}{$\log ($ costs $)$} & Private & & & $\mathrm{N} / \mathrm{S}$ \\
\hline & & & & Private & & De Novo & Positive* \\
\hline & & & & Private & For. & & $\mathrm{N} / \mathrm{S}$ \\
\hline \multirow{10}{*}{2} & \multirow{10}{*}{$\begin{array}{l}\text { Frydman, Gray, Hessel, } \\
\text { and Rapaczynski (1999) }\end{array}$} & \multirow{10}{*}{$\begin{array}{c}\text { Hungary, Poland, Czech } \\
\text { Republic; } \\
\text { 1990-1993; N = } 347\end{array}$} & \multirow{10}{*}{\begin{tabular}{c|}
$\% \Delta$ \\
Costs/Revenues
\end{tabular}} & Private & & & $\mathrm{N} / \mathrm{S}$ \\
\hline & & & & Private & & Outsider & $\mathrm{N} / \mathrm{S}$ \\
\hline & & & & Private & & Insider & $\mathrm{N} / \mathrm{S}$ \\
\hline & & & & Private & For. & & $\mathrm{N} / \mathrm{S}$ \\
\hline & & & & Private & Dom. & Fin. & $\mathrm{N} / \mathrm{S}$ \\
\hline & & & & Private & Dom. & Industrial & $\mathrm{N} / \mathrm{S}$ \\
\hline & & & & Private & Dom. & Individual & $\mathrm{N} / \mathrm{S}$ \\
\hline & & & & State & & & $\mathrm{N} / \mathrm{S}$ \\
\hline & & & & Mngmnt. & & & $\mathrm{N} / \mathrm{S}$ \\
\hline & & & & Worker & & & $\mathrm{N} / \mathrm{S}$ \\
\hline
\end{tabular}


TABLE 8: EFFECT OF OWNERSHIP ON OTHER INDICATORS OF PERFORMANCE

\begin{tabular}{|c|c|c|c|c|c|c|c|c|}
\hline Category & Author(s) & $\begin{array}{c}\text { Country / region, period, } \\
\text { observations }\end{array}$ & $\begin{array}{l}\text { Dependent } \\
\text { variable }\end{array}$ & \multicolumn{4}{|c|}{ Ownership } & Effect \\
\hline \multirow{4}{*}{2} & \multirow{4}{*}{$\begin{array}{l}\text { Frydman, Gray, Hessel, } \\
\text { and Rapaczynski (2000) }\end{array}$} & \multirow{4}{*}{$\begin{array}{l}\text { Hungary, Poland, Czech } \\
\text { Republic; } \\
\text { 1990-1993; N = 53-75 }\end{array}$} & \multirow{4}{*}{$\begin{array}{c}\text { Default on debt } \\
\text { levels }\end{array}$} & State & & & Bnk. Cred. & Positive** \\
\hline & & & & State & & & Tax Auth. & Positive** \\
\hline & & & & State & & & & Positive** \\
\hline & & & & Private & & & Trade Cred. & Negative** \\
\hline \multirow{10}{*}{2} & \multirow{10}{*}{ Miller (2006) } & \multirow{10}{*}{$\begin{array}{c}\text { Bulgaria; } \\
1996-2003 ; N=5360-5964\end{array}$} & \multirow{10}{*}{ Sales/Wages } & State & & Maj. & & $\mathrm{N} / \mathrm{S}$ \\
\hline & & & & State & & Blk. Min. & & $\mathrm{N} / \mathrm{S}$ \\
\hline & & & & Private & & Maj. & & $\mathrm{N} / \mathrm{S}$ \\
\hline & & & & Private & & Blk. Min. & & $\mathrm{N} / \mathrm{S}$ \\
\hline & & & & Private & For. & & & $\mathrm{N} / \mathrm{S}$ \\
\hline & & & & Labor & & & & $\mathrm{N} / \mathrm{S}$ \\
\hline & & & & Private & & Maj. & Fin. & $\mathrm{N} / \mathrm{S}$ \\
\hline & & & & Private & & Blk. Min. & Fin. & $\mathrm{N} / \mathrm{S}$ \\
\hline & & & & Private & & Min. & Hgh. Disp. & Negative** \\
\hline & & & & Private & & Min. & Lw. Disp. & $\mathrm{N} / \mathrm{S}$ \\
\hline \multirow{6}{*}{2} & \multirow{6}{*}{$\begin{array}{c}\text { Prasnikar and Svejnar } \\
\text { (1998) }\end{array}$} & \multirow{6}{*}{$\begin{array}{c}\text { Slovenia; } \\
\text { 1989-1995; } \mathrm{N}=1832\end{array}$} & \multirow{3}{*}{$\begin{array}{l}\text { Investment per } \\
\text { worker }\end{array}$} & Private & & & Ex. Priv. & $\mathrm{N} / \mathrm{S}$ \\
\hline & & & & Private & & & Prev. Own. & Negative** \\
\hline & & & & Private & & & Bypass & Negative** \\
\hline & & & \multirow{3}{*}{$\begin{array}{c}\text { Labor } \\
\text { cost/worker }\end{array}$} & Private & & & Ex. Priv. & $\mathrm{N} / \mathrm{S}$ \\
\hline & & & & Private & & & Prev. Own. & $\mathrm{N} / \mathrm{S}$ \\
\hline & & & & Private & & & Bypass & $\mathrm{N} / \mathrm{S}$ \\
\hline \multirow{3}{*}{3} & \multirow{3}{*}{$\begin{array}{l}\text { Bakanova, Estrin, Pelipas } \\
\text { and Pukovic (2006) }\end{array}$} & \multirow{3}{*}{$\begin{array}{c}\text { Belarus; } \\
2004 ; \mathrm{N}=402\end{array}$} & Exports/Sales & Private & & & De Novo & Positive* \\
\hline & & & $\% \Delta$ Exports & State & & Maj. & & $\mathrm{N} / \mathrm{S}$ \\
\hline & & & $\begin{array}{l}\% \Delta \text { Exports } \\
\text { (West) }\end{array}$ & Private & & Maj. & & $\mathrm{N} / \mathrm{S}$ \\
\hline \multirow{2}{*}{3} & \multirow{2}{*}{ Bojnec (1999) } & \multirow{2}{*}{$\begin{array}{c}\text { Slovenia; } \\
\text { 1989-1996; } \mathrm{N}=248-251\end{array}$} & \multirow{2}{*}{$\begin{array}{l}\text { Demand for } \\
\text { managers }\end{array}$} & Private & & & De Novo & Positive*** \\
\hline & & & & Labor & & & & Negative* \\
\hline
\end{tabular}


TABLE 8: EFFECT OF OWNERSHIP ON OTHER INDICATORS OF PERFORMANCE

\begin{tabular}{|c|c|c|c|c|c|c|c|c|}
\hline Category & Author(s) & $\begin{array}{c}\text { Country / region, period, } \\
\text { observations }\end{array}$ & $\begin{array}{c}\text { Dependent } \\
\text { variable }\end{array}$ & \multicolumn{4}{|c|}{ Ownership } & \multirow{2}{*}{$\begin{array}{c}\text { Effect } \\
\mathrm{N} / \mathrm{S}\end{array}$} \\
\hline \multirow{17}{*}{3} & \multirow{17}{*}{ Claessens (1997) } & \multirow{6}{*}{$\begin{array}{l}\text { Czech and Slovak Republics; } \\
\text { 1992-1993; N = } 1198\end{array}$} & \multirow{6}{*}{$\begin{array}{l}\log (\text { Voucher } \\
\text { price })\end{array}$} & State & & Maj. & & \\
\hline & & & & Private & Dom. & Maj. & & Positive*** \\
\hline & & & & Private & For. & Maj. & & $\mathrm{N} / \mathrm{S}$ \\
\hline & & & & State & & & & Positive* \\
\hline & & & & Private & Dom. & & & Positive** \\
\hline & & & & Private & For. & & & $\mathrm{N} / \mathrm{S}$ \\
\hline & & \multirow{6}{*}{$\begin{array}{c}\text { Czech and Slovak Republics; } \\
\text { 1992-1993; N = 286 }\end{array}$} & \multirow{6}{*}{$\begin{array}{l}\log (\text { Share } \\
\text { price), Stock } \\
\text { exchange }\end{array}$} & State & & Maj. & & $\mathrm{N} / \mathrm{S}$ \\
\hline & & & & Private & Dom. & Maj. & & $\mathrm{N} / \mathrm{S}$ \\
\hline & & & & Private & For. & Maj. & & $\mathrm{N} / \mathrm{S}$ \\
\hline & & & & State & & & & $\mathrm{N} / \mathrm{S}$ \\
\hline & & & & Private & Dom. & & & Positive* \\
\hline & & & & Private & For. & & & Positive* \\
\hline & & \multirow{5}{*}{$\begin{array}{l}\text { Czech and Slovak Republics; } \\
\text { 1992-1993; N = 589 }\end{array}$} & \multirow{5}{*}{$\begin{array}{l}\log (\text { Share } \\
\text { price), OTC }\end{array}$} & State & & Maj. & & $\mathrm{N} / \mathrm{S}$ \\
\hline & & & & Private & Dom. & Maj. & & $\mathrm{N} / \mathrm{S}$ \\
\hline & & & & Private & For. & Maj. & & $\mathrm{N} / \mathrm{S}$ \\
\hline & & & & Private & Dom. & & & Positive** \\
\hline & & & & Private & For. & & & Positive*** \\
\hline \multirow{5}{*}{3} & \multirow{5}{*}{$\begin{array}{l}\text { Cull, Matesova and Shirley } \\
\text { (2002) }\end{array}$} & \multirow{5}{*}{$\begin{array}{c}\text { Czech Republic; } \\
\text { 1993-1996; N = } 1017\end{array}$} & \multirow{5}{*}{ ROA } & Private & For. & Min. & & $\mathrm{N} / \mathrm{S}$ \\
\hline & & & & Private & For. & Maj. & Joint Stock & $\mathrm{N} / \mathrm{S}$ \\
\hline & & & & Private & & Maj. & Joint Stock & Negative*** \\
\hline & & & & Private & & Min. & Joint Stock & Negative*** \\
\hline & & & & State & & & & $\mathrm{N} / \mathrm{S}$ \\
\hline \multirow{2}{*}{3} & \multirow{2}{*}{ Djankov (1999a) } & \multirow{2}{*}{$\begin{array}{l}\text { Georgia, Moldova; } \\
\text { 1995-1997; } \mathrm{N}=241\end{array}$} & \multirow{2}{*}{ Renovations } & Private & & & MBOs & Positive*** \\
\hline & & & & Private & & & Voucher & $\mathrm{N} / \mathrm{S}$ \\
\hline \multirow{3}{*}{3} & \multirow{3}{*}{ Estrin and Rosevear (1999) } & \multirow{3}{*}{$\begin{array}{c}\text { Ukraine; } \\
\text { 1991-1997; } \mathrm{N}=150\end{array}$} & Product & Private & & & Insider & Positive** \\
\hline & & & Input & Private & & & Insider & Positive*** \\
\hline & & & Asset disposal & Private & & & Insider & Positive** \\
\hline \multirow{4}{*}{3} & \multirow{4}{*}{ Grosfeld and Hashi (2007) } & \multirow{4}{*}{$\begin{array}{l}\text { Czech Republic, Poland; } \\
\text { 1994-2000; N = } 653\end{array}$} & \multirow{4}{*}{$\begin{array}{l}\text { Ownership } \\
\text { concentration }\end{array}$} & Private & & & Industrial & Positive*** \\
\hline & & & & Private & & & Fund & Positive* \\
\hline & & & & Private & & & Bank & Positive* \\
\hline & & & & Private & & & Individual & $\mathrm{N} / \mathrm{S}$ \\
\hline 3 & $\begin{array}{l}\text { Hendley, Murrell, and } \\
\text { Ryterman (2001) }\end{array}$ & $\begin{array}{c}\text { Russia; } \\
1997 ; \mathrm{N}=328\end{array}$ & $\begin{array}{c}\text { Success in } \\
\text { transactions }\end{array}$ & Private & & Maj. & & Negative*** \\
\hline 3 & $\begin{array}{l}\text { Jelic, Briston, Aussenegg } \\
\text { (2003) }\end{array}$ & $\begin{array}{l}\text { Czech Republic, Hungary, } \\
\text { Poland; } \\
\text { 1990-2000; } \mathrm{N}=143\end{array}$ & $\begin{array}{l}\text { Byu-and-hold } \\
\text { abnormal } \\
\text { returns }\end{array}$ & Private & For. & & & $\mathrm{N} / \mathrm{S}$ \\
\hline
\end{tabular}


TABLE 8: EFFECT OF OWNERSHIP ON OTHER INDICATORS OF PERFORMANCE

\begin{tabular}{|c|c|c|c|c|c|c|c|c|}
\hline Category & Author(s) & Country / region, period, & $\begin{array}{l}\text { Dependent } \\
\text { yariable }\end{array}$ & \multicolumn{4}{|c|}{ Ownership } & \multirow{2}{*}{$\frac{\text { Effect }}{\mathrm{N} / \mathrm{S}}$} \\
\hline \multirow{5}{*}{3} & \multirow{5}{*}{ Jones (1998) } & \multirow{5}{*}{$\begin{array}{c}\text { Russia; } \\
\text { 1992-1996; } N=93\end{array}$} & \multirow{5}{*}{ Costs } & Private & & SLO & & \\
\hline & & & & Mngmnt. & & SLO & & $\mathrm{N} / \mathrm{S}$ \\
\hline & & & & Worker & & SLO & & Positive** \\
\hline & & & & Private & & SLO & Fin. & Positive** \\
\hline & & & & Private & & SLO & Individual & Positive** \\
\hline \multirow{4}{*}{3} & \multirow{4}{*}{$\begin{array}{c}\text { Konings, Van Cayseele and } \\
\text { Warzynski (2005) }\end{array}$} & \multirow{2}{*}{$\begin{array}{c}\text { Bulgaria; } \\
\text { 1994-1998; } \mathrm{N}=1057\end{array}$} & \multirow{2}{*}{$\begin{array}{l}\text { Price cost } \\
\text { margin }\end{array}$} & Private & For. & Maj. & & $\mathrm{N} / \mathrm{S}$ \\
\hline & & & & Private & Dom. & Maj. & & $\mathrm{N} / \mathrm{S}$ \\
\hline & & \multirow{2}{*}{$\begin{array}{c}\text { Romania; } \\
\text { 1994-1998; } \mathrm{N}=1917\end{array}$} & \multirow{2}{*}{$\begin{array}{l}\text { Price cost } \\
\text { margin }\end{array}$} & Private & For. & Maj. & & $\mathrm{N} / \mathrm{S}$ \\
\hline & & & & Private & Dom. & Maj. & & $\mathrm{N} / \mathrm{S}$ \\
\hline \multirow{3}{*}{3} & \multirow{3}{*}{ Linz (1999) } & \multirow{3}{*}{$\begin{array}{c}\text { Russia; } \\
1992 \& 1995 ; \mathrm{N}=12-590\end{array}$} & \multirow{3}{*}{$\begin{array}{l}\text { Depreciation } \\
\text { rate }\end{array}$} & Private & & & Lease & Negative $^{* * *}$ \\
\hline & & & & Coop. & & & & $\mathrm{N} / \mathrm{S}$ \\
\hline & & & & Private & & & Joint Stock & Positive*** \\
\hline \multirow{6}{*}{3} & \multirow{6}{*}{$\begin{array}{l}\text { Pissarides, Singer and } \\
\text { Svejnar (2003) }\end{array}$} & Russia; 1995; $\mathrm{N}=216$ & \multirow{2}{*}{$\begin{array}{l}\text { Suppliers } \\
\text { constraint }\end{array}$} & Private & & & & $\mathrm{N} / \mathrm{S}$ \\
\hline & & Bulgaria; 1995; $\mathrm{N}=221$ & & Private & & & & $\mathrm{N} / \mathrm{S}$ \\
\hline & & Russia; $1995 ; \mathrm{N}=216$ & \multirow{2}{*}{$\begin{array}{c}\text { Interest rate } \\
\text { constraint }\end{array}$} & Private & & & & $\mathrm{N} / \mathrm{S}$ \\
\hline & & Bulgaria; 1995; $\mathrm{N}=221$ & & Private & & & & Positive** \\
\hline & & Russia; $1995 ; \mathrm{N}=216$ & \multirow{2}{*}{$\begin{array}{l}\text { Office space } \\
\text { constraint }\end{array}$} & Private & & & & $\mathrm{N} / \mathrm{S}$ \\
\hline & & Bulgaria; 1995; $\mathrm{N}=221$ & & Private & & & & Positive** \\
\hline \multirow[b]{2}{*}{3} & \multirow[b]{2}{*}{ Warzynski (2003) } & \multirow[b]{2}{*}{$\begin{array}{c}\text { Ukraine; } \\
\text { 1989-1997; } \mathrm{N}=295\end{array}$} & \multirow{2}{*}{$\begin{array}{l}\text { Managerial } \\
\text { turnover }\end{array}$} & Private & & & $\begin{array}{c}\text { Privatized \& De } \\
\text { Novo }\end{array}$ & Negative*** \\
\hline & & & & Private & & & $\begin{array}{c}\text { Fiancial } \\
\text { difficulties, } \\
\text { Priv.\&DeNovo } \\
\end{array}$ & Positive*** \\
\hline \multirow{2}{*}{3} & \multirow{2}{*}{$\begin{array}{c}\text { Zemplinerova, Lastovicka, } \\
\text { and Marcincin (1995) }\end{array}$} & \multirow{2}{*}{$\begin{array}{c}\text { Czech Republic; } \\
\text { 1991-1993; N = 257 }\end{array}$} & \multirow{2}{*}{$\begin{array}{l}\text { Restructuring } \\
\text { index }\end{array}$} & Private & For. & & & Positive** \\
\hline & & & & Private & Dom. & & & $\mathrm{N} / \mathrm{S}$ \\
\hline 3 & $\begin{array}{c}\text { Zinnes, Eilat and Sachs } \\
\text { (2001) }\end{array}$ & $\begin{array}{c}24 \text { transition countries; } \\
1989-1998 ; \mathrm{N}=173\end{array}$ & GDP & Private & & & & Positive*** \\
\hline
\end{tabular}


TABLE 8: EFFECT OF OWNERSHIP ON OTHER INDICATORS OF PERFORMANCE

\begin{tabular}{|c|c|c|c|c|c|c|c|c|}
\hline Category & Author(s) & $\begin{array}{c}\text { Country / region, period, } \\
\text { observations }\end{array}$ & $\begin{array}{c}\text { Dependent } \\
\text { variable }\end{array}$ & \multicolumn{4}{|c|}{ Ownership } & Effect \\
\hline \multicolumn{9}{|c|}{ PANEL B } \\
\hline \multirow{3}{*}{2} & \multirow{3}{*}{ Qing Gong (2004) } & \multirow{3}{*}{$\begin{array}{c}\text { Liaoning; } \\
\text { 1987-1996; } \mathrm{N}=11467\end{array}$} & \multirow{3}{*}{$\begin{array}{l}\text { Efficiency } \\
\text { Index }\end{array}$} & Coop. & & & & Positive*** \\
\hline & & & & Private & For. & & & Positive*** \\
\hline & & & & & & & Others & $\mathrm{N} / \mathrm{S}$ \\
\hline \multirow{3}{*}{2} & \multirow{3}{*}{ Song and Yao (2004) } & \multirow{3}{*}{$\begin{array}{c}11 \text { cities; } \\
1995-2001 ; N=3290\end{array}$} & \multirow{3}{*}{ Unit costs } & Private & & & Shares & $\mathrm{N} / \mathrm{S}$ \\
\hline & & & & State & & & & Positive*** \\
\hline & & & & Private & & & & Positive** \\
\hline \multirow{3}{*}{2} & \multirow{3}{*}{ Sun, Tong (2003) } & \multirow{3}{*}{$1994-1998 ; \mathrm{N}=634$} & $\begin{array}{c}\text { Cash flow/ total } \\
\text { debt }\end{array}$ & State & & & & $\mathrm{N} / \mathrm{S}$ \\
\hline & & & \multirow{2}{*}{\begin{tabular}{|c|} 
times-Interest \\
earned
\end{tabular}} & Private & & & Industrial & $\mathrm{N} / \mathrm{S}$ \\
\hline & & & & Private & For. & & & $\mathrm{N} / \mathrm{S}$ \\
\hline \multirow{2}{*}{2} & \multirow{2}{*}{ Tian and Estrin (2005) } & \multirow{2}{*}{$1994-1998 ; \mathrm{N}=2660$} & \multirow{2}{*}{ Tobin Q } & State & & & & Positive*** \\
\hline & & & & State & & Maj. & & $\mathrm{N} / \mathrm{S}$ \\
\hline \multirow{2}{*}{2} & \multirow{2}{*}{ Wei, Xie and Zhang (2005) } & \multirow{2}{*}{$1991-2001 ; \mathrm{N}=5284$} & \multirow{2}{*}{ Tobin Q } & State & & & Listed & Negative*** \\
\hline & & & & Private & For. & & Listed & Positive*** \\
\hline \multirow{8}{*}{3} & \multirow{8}{*}{ Chen, Firth, Rui (2006) } & \multirow{8}{*}{$1991-2000 ; \mathrm{N}=735$} & \multirow{2}{*}{$\begin{array}{c}\text { Capital } \\
\text { expenditures/ } \\
\text { Sales } \\
\end{array}$} & Private & For. & & & $\mathrm{N} / \mathrm{S}$ \\
\hline & & & & State & & & & Negative** $^{* *}$ \\
\hline & & & \multirow{2}{*}{$\begin{array}{c}\text { Capital } \\
\text { expenditures/ } \\
\text { Assets } \\
\end{array}$} & Private & For. & & & $\mathrm{N} / \mathrm{S}$ \\
\hline & & & & State & & & & $\mathrm{N} / \mathrm{S}$ \\
\hline & & & \multirow{2}{*}{$\begin{array}{l}\text { Total debt/ } \\
\text { Assets }\end{array}$} & Private & For. & & & Negative** \\
\hline & & & & State & & & & $\mathrm{N} / \mathrm{S}$ \\
\hline & & & \multirow{2}{*}{\begin{tabular}{|} 
Long term debt/ \\
Equity
\end{tabular}} & Private & For. & & & $\mathrm{N} / \mathrm{S}$ \\
\hline & & & & State & & & & $\mathrm{N} / \mathrm{S}$ \\
\hline 3 & Jia, Sun, Tong (2005) & $1993-2002 ; \mathrm{N}=530$ & $\begin{array}{c}\text { Cash flow/total } \\
\text { debt }\end{array}$ & State & & & & $\mathrm{N} / \mathrm{S}$ \\
\hline \multirow{5}{*}{3} & & & & Private & & & & Positive*** \\
\hline & & Jiangsu, Zheiiang: & Accounts & Private & & & $\begin{array}{c}\text { Pre- } \\
\text { privatization }\end{array}$ & $\mathrm{N} / \mathrm{S}$ \\
\hline & Li and Rozelle (2003) & $1994-1999 ; \mathrm{N}=167$ or 575 & $\begin{array}{l}\text { receivable } \\
\text { management }\end{array}$ & Private & & & Premium paying & Positive ${ }^{* * *}$ \\
\hline & & & & Private & & & Mod. Disct. & Positive*** \\
\hline & & & & Private & & & Heav. Disct. & $\mathrm{N} / \mathrm{S}$ \\
\hline
\end{tabular}


TABLE 8: EFFECT OF OWNERSHIP ON OTHER INDICATORS OF PERFORMANCE

\begin{tabular}{|c|c|c|c|c|c|c|c|}
\hline Category & Author(s) & Country / region, period, & Dependent & \multicolumn{3}{|c|}{ Ownership } & Effect \\
\hline \multirow{11}{*}{3} & \multirow{11}{*}{ Li and Rozelle (2001) } & \multirow{11}{*}{$\begin{array}{c}\text { Jiangsu, Zhejiang; } \\
\text { 1994-1997; } N=167 \text { or } 575\end{array}$} & \multirow{4}{*}{$\begin{array}{l}\text { Manager's } \\
\text { workload }\end{array}$} & Private & & & Positive*** \\
\hline & & & & Private & & Post; Prem. & Positive*** \\
\hline & & & & Private & & $\begin{array}{l}\text { Post; Mod. } \\
\text { Disct. }\end{array}$ & $\mathrm{N} / \mathrm{S}$ \\
\hline & & & & Private & & $\begin{array}{l}\text { Post; Heav. } \\
\text { Disct. }\end{array}$ & $\mathrm{N} / \mathrm{S}$ \\
\hline & & & \multirow{7}{*}{$\begin{array}{c}\text { Accounts } \\
\text { receivable } \\
\text { management }\end{array}$} & Private & & & Positive** \\
\hline & & & & Private & & Pre; Prem. & $\mathrm{N} / \mathrm{S}$ \\
\hline & & & & Private & & Pre; Mod. Disct. & Positive*** \\
\hline & & & & Private & & $\begin{array}{l}\text { Pre; Heav. } \\
\text { Disct. }\end{array}$ & $\mathrm{N} / \mathrm{S}$ \\
\hline & & & & Private & & Post; Prem. & Positive*** \\
\hline & & & & Private & & $\begin{array}{l}\text { Post; Mod. } \\
\text { Disct. }\end{array}$ & Positive*** \\
\hline & & & & Private & & $\begin{array}{l}\text { Post; Heav. } \\
\text { Disct. }\end{array}$ & $\mathrm{N} / \mathrm{S}$ \\
\hline \multirow{3}{*}{3} & \multirow{3}{*}{ Tian (2001) } & \multirow{3}{*}{$1985-1997 ; \mathrm{N}=30$} & \multirow{3}{*}{ GDP growth } & State & & & Negative*** \\
\hline & & & & Coop. & & & Positive** \\
\hline & & & & Private & & & Positive** \\
\hline \multirow{2}{*}{3} & \multirow{2}{*}{ Wei and Varela (2003) } & \multirow{2}{*}{$1994-1996 ; \mathrm{N}=252$} & \multirow{2}{*}{ Tobin Q } & State & & & Negative*** \\
\hline & & & & Private & & Fin. & Negative** \\
\hline \multirow{3}{*}{3} & \multirow{3}{*}{ Xu and Wang (1999) } & \multirow{3}{*}{$1993-1995 ; N=673$} & \multirow{3}{*}{ Market/Book } & State & & & $\mathrm{N} / \mathrm{S}$ \\
\hline & & & & Mixed & & Legal entity & Positive*** \\
\hline & & & & Private & & Individual & Negative*** \\
\hline
\end{tabular}

$* * *=$ statistical significance at $1 \%$ level; $* *=$ statistical significance at $5 \%$ level; $*=$ statistical significance at $10 \%$ level;

$\mathrm{N} / \mathrm{S}=$ insignificant effect; Positive/Negative $=$ positive/negative effect

Private $=$ Private ownership; State $=$ State ownership; Worker $=$ Worker ownership $;$ Mngmnt. $=$ Manager ownership

Dom. $=$ Domestic ownershp; For. $=$ Foreign ownership; Maj. = Majority control; Min. $=$ Minority control

Blk. Min. $=$ Blocking minority control; Joint Stock $=$ Joint stock corporation; Voucher $=$ Voucher privatization

Fin. = Financial; Industrial=Ownership by Industrial firm; Mixed = Mixed ownership; Outsider = Outsider ownership; Insider = Insider Ownership;

List. $=$ Listed; Non-List. $=$ Non-Listed; Small = Small firms; Med. \& Lrg. = Medium \& Large firms; De Novo = New firms

Yr. Priv. = Year privatized; Sub. Yrs. $=$ Subsequent years; Shares $=$ Shareholding; Local $=$ Local government control

Cent. $=$ Central government control; Urban = Urban firms; Rural $=$ Rural firms; Joint $=$ joint venture or joint stock companies;

Coop. $=$ Cooperative; Pre $=$ Preprivatization; Post $=$ Postprivatization; Prem. $=$ Premium paying;

Mod. Disct. $=$ Moderately discounted; Heav. Disct. $=$ Heavily discounted; Legal $=$ Legal persons

Hgh. Disp. = High dispersion; Lw. Disp. = Low dispersion 